\title{
CÓRDOBA, ARGENTINA
}

A Territorial Approach to the Sustainable Development Goals in Córdoba, Argentina

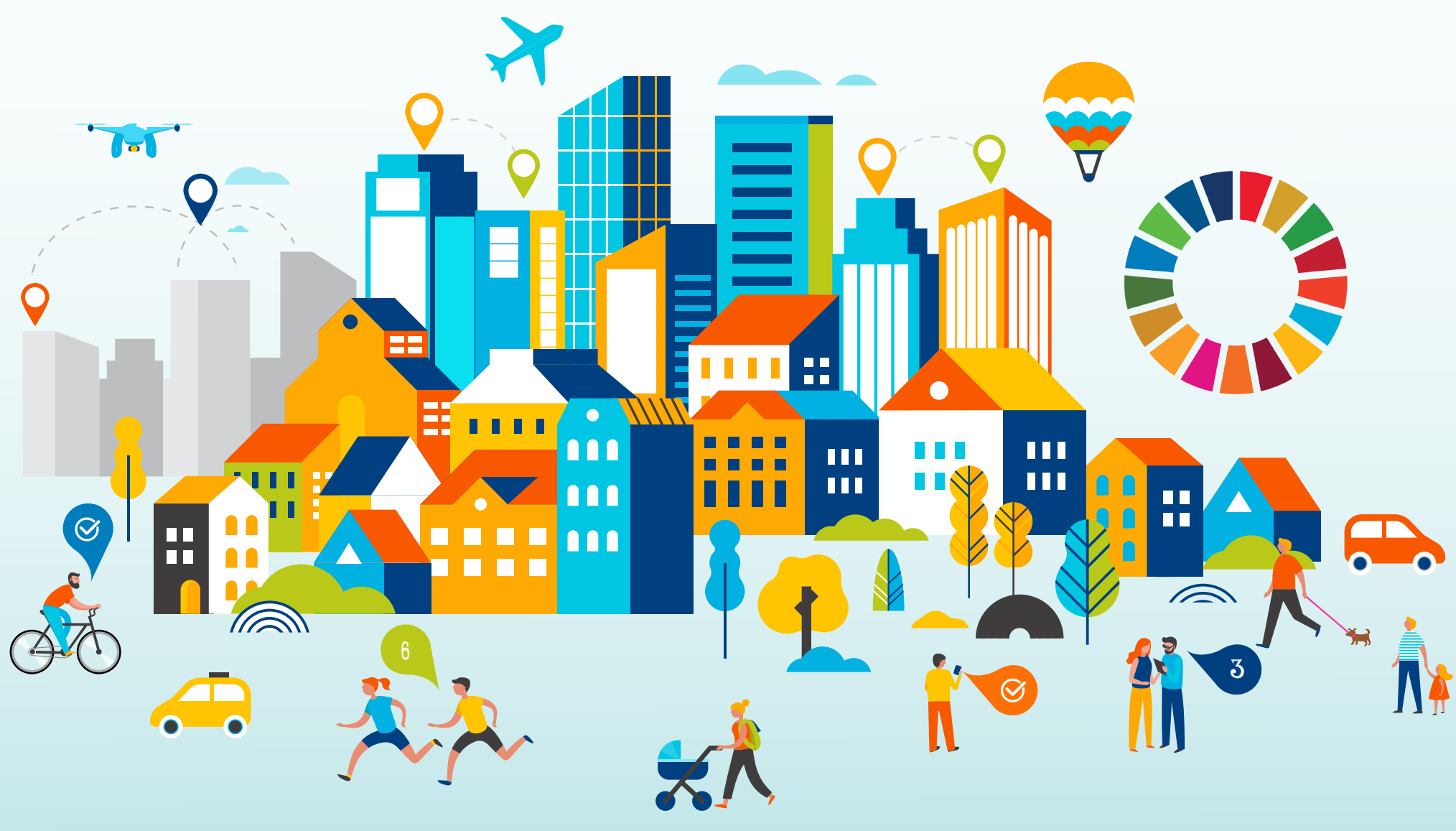




\section{A Territorial Approach to the Sustainable Development Goals in Córdoba, Argentina}




\section{ABOUT THE OECD}

The OECD is a multi-disciplinary inter-governmental organisation of 38 member countries which engages in its work an increasing number of non-members from all regions of the world. The Organisation's core mission today is to help governments work together towards a stronger, cleaner, fairer global economy. Through its network of 250 specialised committees and working groups, the OECD provides a setting where governments compare policy experiences, seek answers to common problems, identify good practice, and co-ordinate domestic and international policies. More information available: www.oecd.org.

\section{ABOUT OECD REGIONAL DEVELOPMENT PAPERS}

Papers from the Centre for Entrepreneurship, SMEs, Regions and Cities of the OECD cover a full range of topics including regional statistics and analysis, urban governance and economics, rural governance and economics, and multi-level governance. Depending on the programme of work, the papers can cover specific topics such as regional innovation and networks, the determinants of regional growth or fiscal consolidation at the sub-national level. OECD Regional Development Papers are published on http://www.oecd.org/cfe/regional-policy.

This paper was authorised for publication by Lamia Kamal-Chaoui, Director, Centre for Entrepreneurship, SMEs, Regions and Cities, OECD.

This document, as well as any statistical data and map included herein, are without prejudice to the status of or sovereignty over any territory, to the delimitation of international frontiers and boundaries and to the name of any territory, city or area.

The statistical data for Israel are supplied by and under the responsibility of the relevant Israeli authorities. The use of such data by the OECD is without prejudice to the status of the Golan Heights, East Jerusalem and Israeli settlements in the West Bank under the terms of international law.

\section{Note by Turkey}

The information in this document with reference to "Cyprus" relates to the southern part of the Island. There is no single authority representing both Turkish and Greek Cypriot people on the Island. Turkey recognises the Turkish Republic of Northern Cyprus (TRNC). Until a lasting and equitable solution is found within the context of the United Nations, Turkey shall preserve its position concerning the "Cyprus issue".

Note by all the European Union Member States of the OECD and the European Union

The Republic of Cyprus is recognised by all members of the United Nations with the exception of Turkey. The information in this document relates to the area under the effective control of the Government of the Republic of Cyprus.

Photo credits: Cover (c) ma_rish/iStock/Getty Images Plus.

\section{(C) OECD 2021}

You can copy, download or print OECD content for your own use, and you can include excerpts from OECD publications, databases and multimedia products in your own documents, presentations, blogs, websites and teaching materials, provided that suitable acknowledgement of OECD as source and copyright owner is given. All requests for public or commercial use and translation rights should be submitted to rights@oecd.org. 


\section{Preface}

The OECD and the province of Córdoba, Argentina, are delighted to introduce the results of the policy dialogue that we conducted over 2 years with more than 100 stakeholders to strengthen a territorial approach to the Sustainable Development Goals (SDGs) in Córdoba, Argentina.

In today's highly uncertain policy environment, and the need to shape long-term recovery measures in response to the COVID-19 pandemic, the SDGs are more relevant than ever. They offer a valuable framework to build a more sustainable and resilient society in a shared responsibility across levels of government.

The regional government of Córdoba, with key challenges in employment opportunities for youth and women, water security, a growing population, and housing availability and affordability, uses the 2030 Agenda and the underlying multi-stakeholder engagement process as a framework to advance and strengthen local governance and policy outcomes. The bottom-up development of an SDG matrix by local stakeholders through which policy challenges and opportunities are appraised, and the creation of an Open Management Portal facilitating access to SDG-related data and governmental actions are two examples of how the region has used the SDGs as a means to strengthen local policy and governance.

The OECD report A Territorial Approach to the Sustainable Development Goals in Córdoba, Argentina provides an assessment of Cordoba's challenges and distance to the SDGs, alongside policy guidance to build a vision of a diversified economic development for the province, reduce the housing deficit through sustainable construction, generate decent work for the most excluded, implement a sustainable water management system and deepen the process of coordination and transparency in policymaking.

Throughout the policy dialogue underlying this report, we shared our experience with a wide variety of stakeholders in Córdoba and learned from peer policymakers from Flanders (Belgium) and Paraná (Brazil). The OECD and the province of Córdoba worked with numerous municipalities and institutions from public, private and non-profit sectors to build consensus, discuss the policy recommendations and scale up success stories.

Both institutions are proud of this journey and the results achieved and look forward to continued collaboration to support the implementation of the policy recommendations in the future.

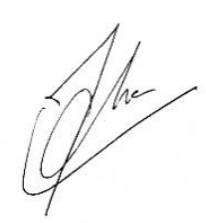

Lamia Kamal-Chaoui,

Director, OECD Centre for Entrepreneurship, SMEs, Regions and Cities

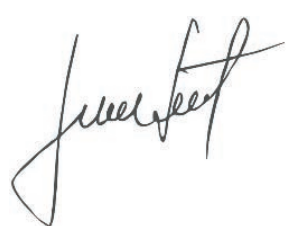

Juan Schiaretti, Governor of the province of Córdoba, Argentina 


\section{Acknowledgements}

This report was prepared by the OECD Centre for Entrepreneurship, SMEs, Regions and Cities (CFE) led by Lamia Kamal-Chaoui, Director, as part of the Programme of Work and Budget of the Regional Development Policy Committee (RDPC). It is the result of a 2-year policy dialogue with more than 100 stakeholders from public, private and non-profit sectors across all levels of government in Córdoba, Argentina.

The report was drafted by a core team of OECD policy analysts comprised of Lorenz Gross and Antonio Canamas Catala of the CFE led by Stefano Marta, Co-ordinator of the OECD Programme on a Territorial Approach to the SDGs, under the supervision of Aziza Akhmouch, Head of the Cities, Urban Policies and Sustainable Development Division in the CFE. The report benefitted from the statistical support of Marcos Díaz Ramírez, who also provided guidance in the analysis of the local SDGs data for the province of Córdoba, Argentina.

The OECD Secretariat is grateful for the high-level political impetus and commitment from Juan Schiaretti, Governor and Silvina Rivero, Minister for Coordination, in the province of Córdoba, Argentina. Special thanks are herein conveyed to the excellent local team, which was directed by Juan Ferreiro, former Secretary for Institutional Strengthening, and composed of Héctor Conti, former Director General of Statistics and Censuses, Ester Curi, Director of Planning and Coordination, Daniel Ortega, Director of Quality of Statistical Processes, Melisa Gorondy Novak and Lucas Conegliano, Project Coordinators at the Secretariat for Institutional Strengthening. Special thanks are also extended to the peer reviewers, who contributed their valuable expertise and experience, participated in missions and provided international best practices as well as guidance on the report, namely Ine Baetens, Sustainable Development Expert for the region of Flanders, Belgium and Geraldo Luiz Farias, Public Manager at Paranacidade in Paraná, Brazil.

The final report was approved via written procedure by the Regional Development Policy Committee (RDPC) on 16 June 2021 under the cote CFE/RDPC/URB(2021)14.

Special thanks are extended to François Iglesias and Pilar Philip in the CFE for preparing the report for publication, as well as to Eleonore Morena for editing and formatting the report. 


\section{Table of contents}

$\begin{array}{ll}\text { Preface } & 3\end{array}$

$\begin{array}{ll}\text { Acknowledgements } & 4\end{array}$

$\begin{array}{lc}\text { Abbreviations and acronyms } & 8\end{array}$

Executive summary 10

1 The SDGs as a tool to promote social inclusion in the province of Córdoba, Argentina 13

Key facts about the province of Córdoba, Argentina 14

Policies and strategies for the 2030 Agenda and the SDGs in Córdoba, Argentina 16

The Government Management Report and its three key axes of government action 16

Promoting social inclusion in Córdoba: From well-being to the SDGs 19

$\begin{array}{lr}\text { References } & 23\end{array}$

2 Sustainable development challenges and opportunities in Córdoba, Argentina 25

The importance of data-driven policies: Córdoba's work on SDGs indicators 26

Measuring the distance to the SDGs in Córdoba, Argentina 26

People: Córdoba's performance on health and gender equality is above the average of Latin

American regions but below the OECD average

Planet: Satisfaction with water quality and degree of terrestrial protection are above the Argentinian average but tree cover and water body volumes are decreasing 34

Prosperity: Córdoba benefits from a highly educated population compared to most of its Latin American peers but labour market outcomes and infrastructure satisfaction indicators are lower than OECD averages

Peace and Partnership: Low homicide rates compared to its Latin American peers but indicators on perceived safety and trust in the judicial system are below OECD averages

References

Notes

(1) (1) 8 10 3 4

16
5 6 
A participatory matrix to identify the drivers of social inclusion in Córdoba 54

The process of the territorialisation of the SDGs in the province of Córdoba 54

The SDGs as a means to respond to interlinked sustainability challenges in Córdoba $\quad 61$

Annex 3.A. List of SDG targets adapted to the context of the province of Córdoba 63

References $\quad 65$

Note 66

4 Policy recommendations and action plan 67

$\begin{array}{ll}\text { Policy recommendations and action plan } & 68\end{array}$

Key recommendations for Córdoba $\quad 69$

Planning, policies and strategies $\quad 71$

Multi-level governance $\quad 75$

Financing and budgeting $\quad 76$

$\begin{array}{ll}\text { Data and information } & 77\end{array}$

$\begin{array}{ll}\text { Engagement } & 78\end{array}$

$\begin{array}{ll}\text { References } & 80\end{array}$

\section{Tables}

Table 1.1. Territorial characteristics of the Córdoba agglomerations 14

Table 1.2. Córdoba's development priorities, OECD regional well-being framework dimensions and the SDGs 19

Table 2.1. Indicators from the OECD Regional Well-Being framework used to complement the assessment of the province of Córdoba, Argentina

Table 2.2. OECD indicators used to assess the dimension People in Córdoba 31

Table 2.3. OECD indicators used to assess the dimension Planet in Córdoba 34

Table 2.4. OECD indicators used to assess the dimension Prosperity in Córdoba 37

Table 2.5. OECD indicators used to assess the dimensions Peace and Partnership in Córdoba 40

Table 3.1. Non-exhaustive list of companies active on the SDGs in Córdoba 50

Table 3.2. Non-exhaustive list of civil society organisations in Córdoba active on the SDGs 52

Table 3.3. Non-exhaustive list of universities and research institutes in Córdoba active on the SDGs 53

Table 3.4. Relationship matrix between prioritised targets and SDGs in Córdoba 56

Table 3.5. Main outcomes of the third workshop on the territorialisation of the SDGs in Córdoba 59

Annex Table 3.A.1. List of the 42 SDG targets adapted to the context of the province of Córdoba 63

\section{Figures}

Figure 1.1. Regional GDP growth rates in the province in Córdoba (\%), 2005-17 15

Figure 1.2. The three axes of governmental action in the province of Córdoba 17

Figure 1.3. Categorisation of the different SDGs in the province of Córdoba 18

Figure 1.4. The OECD analytical framework for A Territorial Approach to the SDGs 22

Figure 2.1. The 17 Sustainable Development Goals 27

Figure 2.2. Map of the province of Córdoba and its four main agglomerations 30

Figure 2.3. Mortality rates (number of deaths) for the 0-4 year-old population per 10000 people, $2017 \quad 33$

Figure 2.4. Change in tree cover (percentage points), 1992-2015 36

Figure 2.5. Exposure to PM2.5 in $\mu \mathrm{g} / \mathrm{m}^{3}$, population-weighted (micrograms per cubic metre), $2017 \quad 39$

Figure 2.6. Homicides per 100000 persons, 2016

Figure 2.7. Percentage of households with broadband Internet access, 2016

Figure 3.1. SDG territorialisation process in Córdoba - Methodology and main priorities $\quad 55$

Figure 3.2. Key drivers for the achievement of Córdoba's prioritised SDGs 58

Figure 3.3. Interlinkages between Córdoba's priority targets and SDG $1 \quad 58$

Figure 3.4. Relationship between the 42 prioritised targets and the 6 SDGs selected as priorities by the
province of Córdoba

Figure 3.5. Population development in the province of Córdoba (1960-2040) 61

Figure 4.1. Seven key recommendations for a territorial approach to the SDGs in Córdoba 70 
Figure 4.2. Action plan to implement OECD Recommendation 1 to design concrete policies for the achievement of the 2030 Agenda - First part

Figure 4.3. Action plan to implement OECD Recommendation 1 to design concrete policies for the achievement of the 2030 Agenda - Second part

Figure 4.4. Action plan to implement OECD Recommendation 1 to design concrete policies for the achievement of the 2030 Agenda - Third part

Figure 4.5. Action plan to implement OECD Recommendation 2 to use the SDGs to develop a Vision 2030 for the province of Córdoba jointly with all key territorial stakeholders

Figure 4.6. Action plan to implement OECD Recommendation 3 to strengthen the vertical and horizontal coordination of the SDGs

Figure 4.7. Action plan to implement OECD Recommendation 4 to use the SDGs as a budgeting tool and leverage public procurement to introduce sustainability criteria

Figure 4.8. Action plan to implement OECD Recommendation 5 to enhance the availability and dissemination of data to the public

Figure 4.9. Action plan to implement OECD Recommendation 6 to provide platforms to co-ordinate the actions of the private sector and civil society on the SDGs

Figure 4.10. Action plan to implement OECD Recommendation 7 to define a strategy for the engagement of the private sector

\section{Boxes}

Box 1.1. OECD Territorial Review of Córdoba, $2016 \quad 20$

Box 1.2. Why a territorial approach to the SDGs? 21

Box 2.1. OECD methodology for measuring cities' and regions' distance to the SDGs 27

Box 2.2. Limitations and considerations of subnational indicators from Gallup World Poll 28

Box 3.1. Federal structure of Argentina $\quad 46$

Box 3.2. Horizontal and vertical policy co-ordination in the province of Córdoba 47

Box 3.3. Methodology for the SDG territorialisation process in the province of Córdoba, Argentina 55

Box 4.1. OECD Checklist for Public Action to facilitate and uptake the implementation of the SDGs 68

Box 4.2. OECD Action Plan for a territorial approach to the SDGs in Córdoba 69

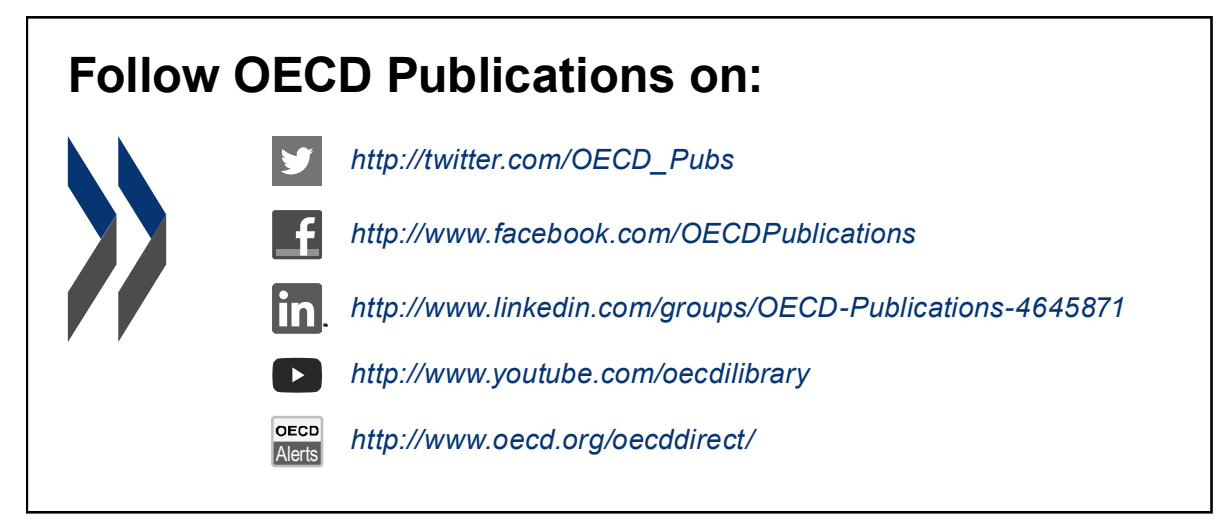




\section{Abbreviations and acronyms}

\begin{tabular}{|c|c|}
\hline AASAP & Argentine Public Health Association (Asociación Argentina de Salud Pública) \\
\hline BMZ & $\begin{array}{l}\text { Federal Ministry for Economic Cooperation and Development (Bundesministerium } \\
\text { für wirtschaftliche Zusammenarbeit und Entwicklung) }\end{array}$ \\
\hline $\begin{array}{l}\text { CEVE- } \\
\text { CONICET }\end{array}$ & $\begin{array}{l}\text { Experimental Centre of Economic Housing (Centro Experimental de la Vivienda } \\
\text { Económica) }\end{array}$ \\
\hline CFE & OECD Centre for Entrepreneurship, SMEs, Regions and Cities \\
\hline CITeQ & $\begin{array}{l}\text { Centre for Chemical Research and Technology (Centro de Investigación y } \\
\text { Tecnología Química) }\end{array}$ \\
\hline CNCPS & $\begin{array}{l}\text { National Council for the Coordination of Social Policies (Consejo Nacional de } \\
\text { Coordinación de Políticas Sociales) }\end{array}$ \\
\hline CSR & Corporate social responsibility \\
\hline DGEyC & $\begin{array}{l}\text { General Directorate of Statistics and Censuses (Dirección General de Estadística y } \\
\text { Censos) }\end{array}$ \\
\hline ESCR & Economic, social, cultural and environmental rights \\
\hline FDS & Foundation for Sustainable Development (Fundación para el Desarrollo Sostenible) \\
\hline Gallup & Gallup World Poll \\
\hline GDP & Gross domestic product \\
\hline GRI & Global Reporting Initiative \\
\hline IARSE & $\begin{array}{l}\text { Argentinian Institute for Corporate Social Responsibility (Instituto Argentino de } \\
\text { Responsabilidad Social Empresaria) }\end{array}$ \\
\hline IBR-IRE & $\begin{array}{l}\text { Institute of Registered Auditors (Instituut van de Bedrijfsrevisoren - Institut des } \\
\text { Reviseurs d'Entreprises) }\end{array}$ \\
\hline ICT & Information and communication technology \\
\hline INDEC & National Institute of Statistics and Censuses \\
\hline IPCaM & $\begin{array}{l}\text { Provincial Institute of Municipal Training (Instituto Provincial de Capacitación } \\
\text { Municipal) }\end{array}$ \\
\hline ISO & International Organization for Standardization \\
\hline MDG & Millennium Development Goals \\
\hline NGO & Non-governmental organisation \\
\hline OGP & Open Government Partnership \\
\hline PM & Particulate matter \\
\hline PRMEs & Principles of Responsible Management \\
\hline PSU & Primary Sampling Unit \\
\hline RDPC & Regional Development Policy Committee \\
\hline SDGs & Sustainable Development Goals \\
\hline SFI & $\begin{array}{l}\text { Secretariat for Institutional Strengthening (Secretaría de Fortalecimiento } \\
\text { Institucional) }\end{array}$ \\
\hline SINTyS & $\begin{array}{l}\text { National Tax and Social Identification System (Sistema de Identificación Nacional } \\
\text { Tributario y Social) }\end{array}$ \\
\hline & ice Agen \\
\hline
\end{tabular}


Welt)

SME Small- and medium-sized enterprise

STEM Science, technology, engineering, mathematics

UIC

Industry Association of Córdoba (Unión Industrial de Córdoba)

UN

United Nations

UTN

National Technological University (Universidad Tecnológica Nacional)

VVSG

Association of Flemish Cities and Municipalities (Vereniging van Vlaamse Steden en Gemeenten)

WHO

World Health Organization 


\section{Executive summary}

The province of Córdoba, Argentina, uses the SDGs as a framework to promote social inclusion and wellbeing. Providing affordable housing, addressing the gender gap in unemployment, reducing air pollution, and improving water quality are key priorities to advance regional development and social inclusion. The SDGs provide a holistic framework to address these challenges in an integrated way and can help to identify the drivers of social inclusion in the province of Córdoba. For this reason, the province has undertaken a multi-stakeholder engagement process, which has led to five strategic lines of action for the achievement of the SDGs in Córdoba to: i) build a vision of multidimensional economic development for the province, ii) bridge the housing supply gap and foster sustainable construction, iii) generate decent work for the most excluded, iv) implement a sustainable water management system and v) deepen the process of coordination and transparency in policymaking.

\section{Key findings}

\section{Córdoba is using the SDGs to move forward the social inclusion and well-being agenda}

- Córdoba mainstreamed the SDGs in its governmental actions as a tool to promote social inclusion and well-being. In particular, the yearly Government Management Report prioritises the SDGs on poverty, zero hunger, health, education, gender and inequality to generate more inclusive growth and well-being for all.

- Córdoba has established three axes of governmental action, namely social justice, sustainable economic growth and strengthening institutions, linked to the SDGs. The social justice axis and SDG 10 Reduced inequalities are the priorities of the provincial government. The sustainable economic growth axis is seen as a means to promote social inclusion through the actions of the various sectors of the economy. Finally, the axis on strengthening institutions focuses on promoting dialogue and partnerships to build solid institutions and partnerships.

- Córdoba also seeks to promote evidence-based policymaking for greater transparency and accountability. Building on its experience in measuring regional well-being, Córdoba has developed a framework to measure progress against all 17 SDGs through 115 indicators.

\section{Although Córdoba performs below the OECD average across the majority of SDG targets, it outperforms several Latin American peers in several SDGs}

- Córdoba's strengths in comparison to OECD and Latin American regions lie primarily in the areas of inequality and health:

- Income inequality in Córdoba is lower than in $87 \%$ of OECD regions. Only around $24 \%$ of the population in Córdoba's four main agglomerations lived below the relative poverty line (60\% of regional median disposable income in 2018). Likewise, its regional Gini coefficient 
of gross income (0.37) was 10 Gini points below the OECD average (0.47) and 13 Gini points below the average observed in Mexico and Chile (0.5).

- In comparison to Latin American regions, Córdoba has overall considerably higher achievements regarding health indicators, and its child-mortality rate (10.5 deaths per 10 000 people aged 0-4) in 2017 was lower than the OECD regions average (11.8).

- Challenges exist across several dimensions of the 2030 Agenda, notably air pollution, housing, water and safety:

- In 2017, the population's average exposure to particulate matter (PM) 2.5 was $15.1 \mu \mathrm{g} / \mathrm{m}^{3}$ (annual mean), 5 micrograms per cubic metre above the WHO air quality guidelines.

- Rents accounted for around 30\% of household gross income (of tenant households) in Córdoba's four main agglomerations in 2018 , which suggests that housing is becoming unaffordable based on the UN SDGs global indicator framework.

- Between 1992 and 2019, the province of Córdoba's water bodies decreased by 0.8 percentage points, among the largest decreases relative to OECD and other Latin American regions.

- Cordoba's homicide rate of 4.5 deaths per 100000 people in 2019 was higher than in about $75 \%$ of OECD regions, albeit among the lowest $10 \%$ of peer regions in Latin America.

\section{The province has put in place a multi-stakeholder engagement process to advance priority SDG targets}

- To promote vertical co-ordination, the province of Córdoba has signed a co-operation agreement with the National Council for the Coordination of Social Policies (CNCPS). This agreement facilitates national support to leverage the SDGs as a management and planning tool at the provincial level, yet there is little ongoing regular exchange between the provincial and national level on the implementation of the SDGs.

- The Ministry for Coordination acts as the SDG focal point and coordinates the InterMinisterial SDG Board in Córdoba. The board acts as a forum where SDG-related programmes, initiatives and indicators are analysed and elaborated by representatives of all provincial departments through horizontal coordination.

- Civil society is actively engaged in the regional 2030 Agenda but private sector engagement could be strengthened. While many civil society organisations are aware of the SDGs and carry out related activities, companies are less acquainted with the 2030 Agenda. Through the Córdoba SDG Forum, the province has established a mechanism for exchange among civil society actors, which could be further institutionalised, alongside stronger integration of the SDGs into companies' core business activities.

\section{Policy recommendations}

To leverage a territorial approach to the SDGs in Córdoba, the province should:

- Design concrete policies for the achievement of the 2030 Agenda building on the identified strategic lines of actions:

- Promote a diversified economic development through aligning provincial infrastructure policies and coordinating with local authorities during both the design and implementation phases of infrastructure and regional development plans;

- Bridge the housing supply gap and foster sustainable construction, through expanding the collaboration between the province and its municipalities on land-use 
planning policy and regulation to establish a coherent long-term housing development strategy;

- Generate decent work for the most excluded through leveraging fiscal advantages and instruments such as tax benefits for young entrepreneurs and enterprises to incentivise the creation of new businesses and employment opportunities in the province supported by business incubators;

- Enhance sustainable water and sanitation management through a dedicated strategy to map, target and manage water-related risks, underpinned with granular data on water quantity, quality and pollution, and via the creation of water restoration programmes;

- Use the SDGs to develop a Vision 2030 for the province of Córdoba, jointly with all key territorial stakeholders. Such a vision should contribute to the elaboration of a formalised regional development strategy aimed at diversifying the provincial economy, strengthening participation in global value chains and sustaining well-being.

- Strengthen the vertical and horizontal co-ordination of the SDGs. A co-ordinated approach to the implementation of the SDGs, building on the agreement with the National Council for Coordination of Social Policies, could create synergies between provincial and municipal actions and the development of best-practices.

- Use the SDGs as a budgeting tool and leverage public procurement to introduce sustainability criteria such as International Organization for Standardization (ISO) certifications and incentivise public and private actors' initiatives for sustainable development.

- Enhance the availability and dissemination of data to the public through the collection and dissemination of up-to-date SDG-relevant metrics and evidence to raise awareness and call for action.

- Provide platforms to coordinate the actions of the private sector and civil society on the SDGs. The establishment of the Córdoba SDG Forum is a good example that could be incorporated into the framework of a 2030 Vision for Córdoba to raise awareness, share good practices and boost collaborations. 


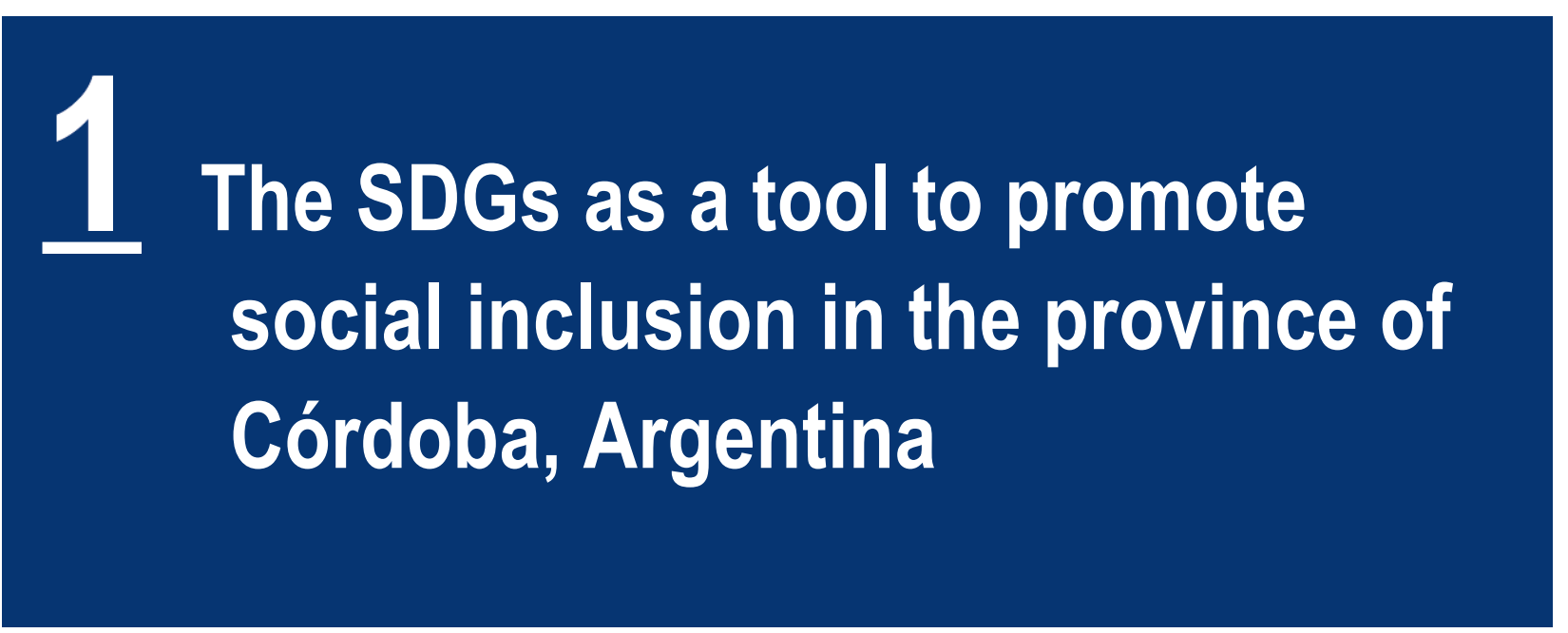

The province of Córdoba, Argentina's second-most populous province, has started a process to link its government actions to the 2030 Agenda, seeing such an alignment as an opportunity to advance and strengthen its management model. Through its government management report, Córdoba has established three axes of governmental action linked to the Sustainable Development Goals (SDGs) - social justice, sustainable economic growth and strengthening institutions. The social justice axis and the achievement of SDGs no poverty, zero hunger, good health, quality education, gender equality and reduced inequalities (1-5 and 10) are the priority of the provincial government. Córdoba's current efforts to localise the SDGs build on the previous joint work with the OECD on regional well-being and sustainable development. 


\section{Key facts about the province of Córdoba, Argentina}

Córdoba is a province located in the centre of Argentina. The province extends over an area of 165 $321 \mathrm{~km}^{2}$, making it the fifth-largest among the country's 23 provinces. In terms of population size, Córdoba is the second-most populous province counting around 3.7 million residents in 2018 (Government of the Province of Córdoba, 2019[1]]). Like most of the other provinces in Argentina, Córdoba is highly urbanised with approximately $87 \%$ of the population living in urban areas in 2010 (OECD, 2016[2]). Around 2 million people (55\% of its population) live in its the 4 main agglomerations, namely Grand Córdoba, which also includes the provincial capital of Córdoba with 1.4 million residents, Río Cuarto-Las Higueras, San Francisco and Villa María-Villa Nueva (OECD, 2019 ${ }_{[3]}$ ). The administrative geography of the province of Córdoba presents a relatively high degree of fragmentation compared to other provinces, encompassing 26 departments and a total of 427 municipalities (260 municipios and 167 comunas), while the average number of municipalities per province in Argentina is 91 (OECD, 2016[2]).

\section{Table 1.1. Territorial characteristics of the Córdoba agglomerations}

\begin{tabular}{|c|c|c|c|c|c|c|c|}
\hline & $\begin{array}{l}\text { Departments in } \\
\text { which located }\end{array}$ & $\begin{array}{c}\text { Area of the } \\
\text { agglomeration } \\
\left(\mathrm{km}^{2}\right)\end{array}$ & $\begin{array}{l}\text { Percentage } \\
\text { of the } \\
\text { department's } \\
\text { area }\end{array}$ & $\begin{array}{l}\text { Percentage } \\
\text { of the } \\
\text { province's } \\
\text { area }\end{array}$ & $\begin{array}{l}\text { Population } \\
\text { of the } \\
\text { agglomeration } \\
\text { (persons, 2010) }\end{array}$ & $\begin{array}{l}\text { Percentage } \\
\text { of the } \\
\text { department's } \\
\text { population }\end{array}$ & $\begin{array}{l}\text { Percentage } \\
\text { of the } \\
\text { province's } \\
\text { population }\end{array}$ \\
\hline $\begin{array}{l}\text { Gran } \\
\text { Córdoba }\end{array}$ & Capital and Colón & 532.86 & 18.29 & 0.32 & 1490629 & 95.88 & 45.05 \\
\hline $\begin{array}{l}\text { Río } \\
\text { Cuarto- } \\
\text { Las } \\
\text { Higueras }\end{array}$ & Río Cuarto & 69.88 & 0.38 & 0.04 & 164500 & 66.76 & 4.97 \\
\hline $\begin{array}{l}\text { Villa } \\
\text { María- } \\
\text { Villa } \\
\text { Nueva }\end{array}$ & General San Martín & 42.68 & 0.86 & 0.03 & 99308 & 77.92 & 3.00 \\
\hline $\begin{array}{l}\text { San } \\
\text { Francisco }\end{array}$ & San Justo & 37.6 & 0.24 & 0.02 & 62211 & 30.15 & 1.88 \\
\hline $\begin{array}{l}\text { Córdoba } \\
\text { agglomer } \\
\text { ations }\end{array}$ & & 683.02 & 1.62 & 0.41 & 1816648 & 85.09 & 54.9 \\
\hline
\end{tabular}

Note: The municipalities included in each of the four agglomerations are as follows. Gran Córdoba agglomeration: Agua de Oro, Córdoba, El Manzano, Estación, Juárez Celman, La Calera, La Granja, Malvinas Argentinas, Mendiolaza, Parque Norte, Río Ceballos, Saldán, Salsipuedes and Unquillo. Río Cuarto-Las Higueras agglomeration. Villa María agglomeration: Villa María and Villa Nueva. San Francisco agglomeration: San Francisco.

Source: OECD (2019[3]), How's Life in the Province of Córdoba, Argentina?, https://doi.org/10.1787/97f189b1-en based on INDEC (2010[4]), National Census on Population, Households, and Housing, https://www.indec.gob.ar/indec/web/Nivel4-Tema-2-41-135.

Historically, the province of Córdoba has been a key contributor to national gross domestic product (GDP) and economic growth. From 1993 to 2012, Córdoba's GDP grew at an average annual rate of $3.2 \%$, slightly below the national average of $3.7 \%$. The growth trajectory of the province over the past three decades has not been smooth. After three periods of economic contractions with negative GDP growth, in 1995, 1999 and 2001-02, Córdoba, however, like the rest of Argentina, went through a period of sustained growth (OECD, 2016[2]). The year 2009 saw a stop in the provincial GDP expansion, followed by years of relatively large fluctuations in the growth rate between $-6 \%$ and $12 \%$, which averaged at $3 \%$ between 2010 and 2017 (Figure 1.1). Resulting from the increase in GDP, Córdoba registered a per capita GDP of around USD 12 702 in 2017. Overall, the contribution of Córdoba's economy to the national GDP (at current prices) has fluctuated between $8.3 \%$ and $9.4 \%$ in the period 2004 to 2017 , making it a key contributor to the national 
GDP among Argentinian provinces (Government of the Province of Córdoba, 2019[1]]). Using constant prices (base year: 2004), Córdoba's contribution to national GDP was between $8.3 \%$ and $10.0 \%$ over the same period.

Figure 1.1. Regional GDP growth rates in the province in Córdoba (\%), 2005-17

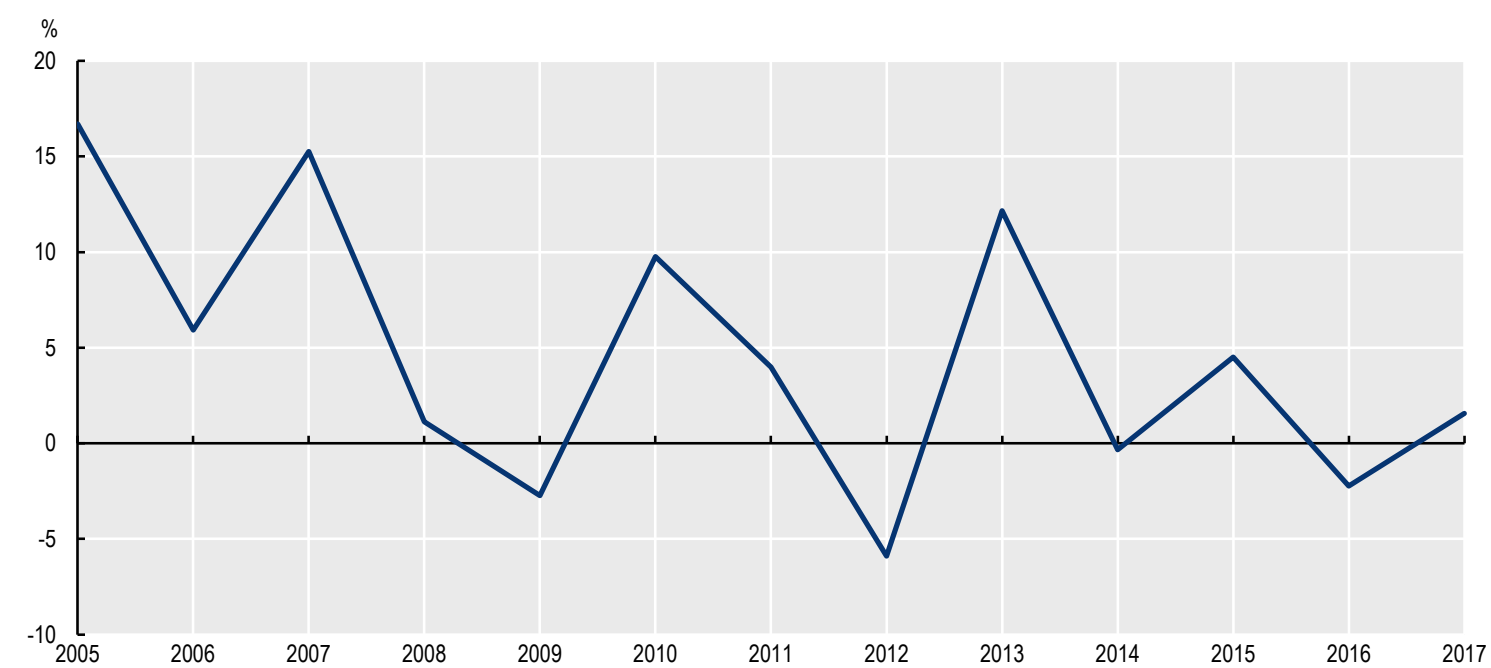

Source: General Directorate of Statistics and Censuses (2020[5]), Producto Bruto Regional - Informe provincial y departamentales 2017 [Gross Regional Product - Provincial and Departmental Report 2017], Province of Córdoba, https://datosestadistica.cba.gov.ar/dataset/producto-brutoregional (accessed on 13 August 2020).

Córdoba exhibits a diversified economy based on a strong agricultural sector, manufacturing and information and communication technology (ICT) services. The contribution to Córdoba's GDP is relatively balanced between the services and good-producing sector. In 2017, the services sector contributed around $53 \%$ of the provincial GDP, notably through commercial activities $(17.8 \%)$, real estate $(9.6 \%)$ and transport (8.1\%) (Government of the Province of Córdoba, 2019 $9_{[1]}$ ). The services sector is particularly clustered in the main agglomerations. The goods-producing sector represented around $47 \%$ of the provincial economy in the same year. It is primarily composed of the agricultural sector, accounting for $22.5 \%$ of the provincial GDP in 2017 , the manufacturing industry $(15.1 \%)$ and the constructions and building sector $(7.4 \%)$ (Government of the Province of Córdoba, 2019[1]]. Among the most competitive subsectors in the province are: i) crop agriculture and the food production industry, which are benefitting from a combination of fertile soil and a subtropical Mediterranean climate; ii) traditional manufacturing in the automotive and agro-machinery industries; iii) ICT; and iv) tourism (OECD, 2016 $[2]$ ).

Within the province of Córdoba, economic activities mirroring population settlements are highly concentrated in a small number of departments. In 2017, 9 of the 26 departments generated around $78 \%$ of the provincial GDP. This distribution has been relatively stable over time. The capital department, having a high concentration of economic activity with respect to other provincial departments, contributed more than one-third of the provincial GDP. Its share has remained stable in the last years. The other largest contributors to Córdoba's GDP were the departments of Río Cuarto and San Justo that contributed approximately $9 \%$ and $8 \%$ of the GDP respectively in 2017 .

Córdoba's exports are dominated by processed food and manufacturing products. In 2017, Córdoba exported goods and services worth USD 8.1 billion - down from USD 11 billion in 2013. This corresponds to around $14 \%$ of all Argentinian exports, with Brazil (11.6\%), China (9.8\%), Viet Nam (8.6\%), the Netherlands (5.6\%) and Chile (4.5\%) being the 5 main destinations. Manufactured goods of agricultural origin, mostly soy flour and soy oil, and industrial origin, mainly vehicle and tractor parts and components 
accounted for around two-thirds of Córdoba's exports (62\%), while primary production, mainly corn and soy, contributed the remaining 38\% (General Directorate of Statistics and Censuses, $2019_{[6]}$ ). The value of imports to Córdoba (USD 2.1 billion in 2017) is considerably lower than the value of its exports. The main import products in the province are motor vehicles, tractors, cycles and other land vehicles, and parts and accessories thereof as well as nuclear reactors, boilers, machinery and mechanical appliances that accounted for more than $50 \%$ of the province's imports in 2017. Around half of the imports come from Brazil (General Directorate of Statistics and Censuses, 2019 $\left[9_{[7]}\right)$.

In the OECD's Regional Well-Being framework, the province of Córdoba and its four main agglomerations more specifically displayed living standards above the average of Latin American regions. In particular, the province enjoys high levels of community and social support. Its population also has higher levels of educational attainment and is less exposed to violent crimes compared to peer regions in Chile and Mexico. Income in its main agglomerations is equivalent to $80 \%$ of the OECD average but lower than in $60 \%$ of OECD regions, while inequality is lower than in the majority of Latin American peer regions. The province's performance in the dimensions of health and housing is however, more challenging (OECD, 2019[3]).

The province of Córdoba is one of the main academic centres of Argentina, with higher education being a key asset of the province. Córdoba has long been referred to as La Docta (The Learned One) since the establishment of the National University of Córdoba in 1613, making it the third-oldest university in South America. Nowadays, Córdoba is home to a total of 12 universities, 6 of them private, where around 160 000 students are enrolled, most of them at the National University of Córdoba, which is the second-largest in the country. Córdoba further hosts Argentina's largest online university, the $21^{\text {st }}$ Century University, which had more than 60000 students enrolled in the 2018 academic year. University enrolment is however largely concentrated in the provincial capital with only a few campuses located elsewhere (Oxford Business Group, 2018[8]).

\section{Policies and strategies for the 2030 Agenda and the SDGs in Córdoba, Argentina}

\section{The Government Management Report and its three key axes of government action}

Córdoba has started a process to implement regional development policies using the SDGs as a framework with an emphasis on social inclusion and well-being. The province of Córdoba uses its Government Management Report (Memoria de Géstion Gubernamental), a publication that summarises the provincial government's development, projects and initiatives, to showcase how its work is linked to the SDGs. The actions the province of Córdoba has undertaken to achieve the SDGs have been compiled and published annually in the report since 2016, applying the methodology of the Global Reporting Initiative (GRI), a global framework for comparison. The GRI methodology allows companies and organisations to harmonise their communication on the social, economic and environmental impacts of their activities. Córdoba is the first province in Argentina to report its management performance under this methodology, whose standards represent best practices at a global level for publicly reporting the economic, environmental and social impacts of a government organisation. The latest version of Córdoba's Government Management Report was released in May 2019. It aligns the various initiatives of the provincial government with the SDGs and was developed in dialogue with the various ministries and agencies.

Córdoba has established three axes of governmental action linked to the SDGs - social justice, sustainable economic growth and strengthening institutions. The progress the province is making on these three axes is published annually in its Government Management Report (Figure 1.2). In the reports of 2016, 2017, 2018 and 2019, the provincial government stresses that sustainability is a key principle guiding the actions of the government. Each government initiative, programme and plan of the government should aim to strengthen the collective capacity to build a province based on the principles of sustainable development (Government of the Province of Córdoba, 2019 $[1]$ ). 
Figure 1.2. The three axes of governmental action in the province of Córdoba

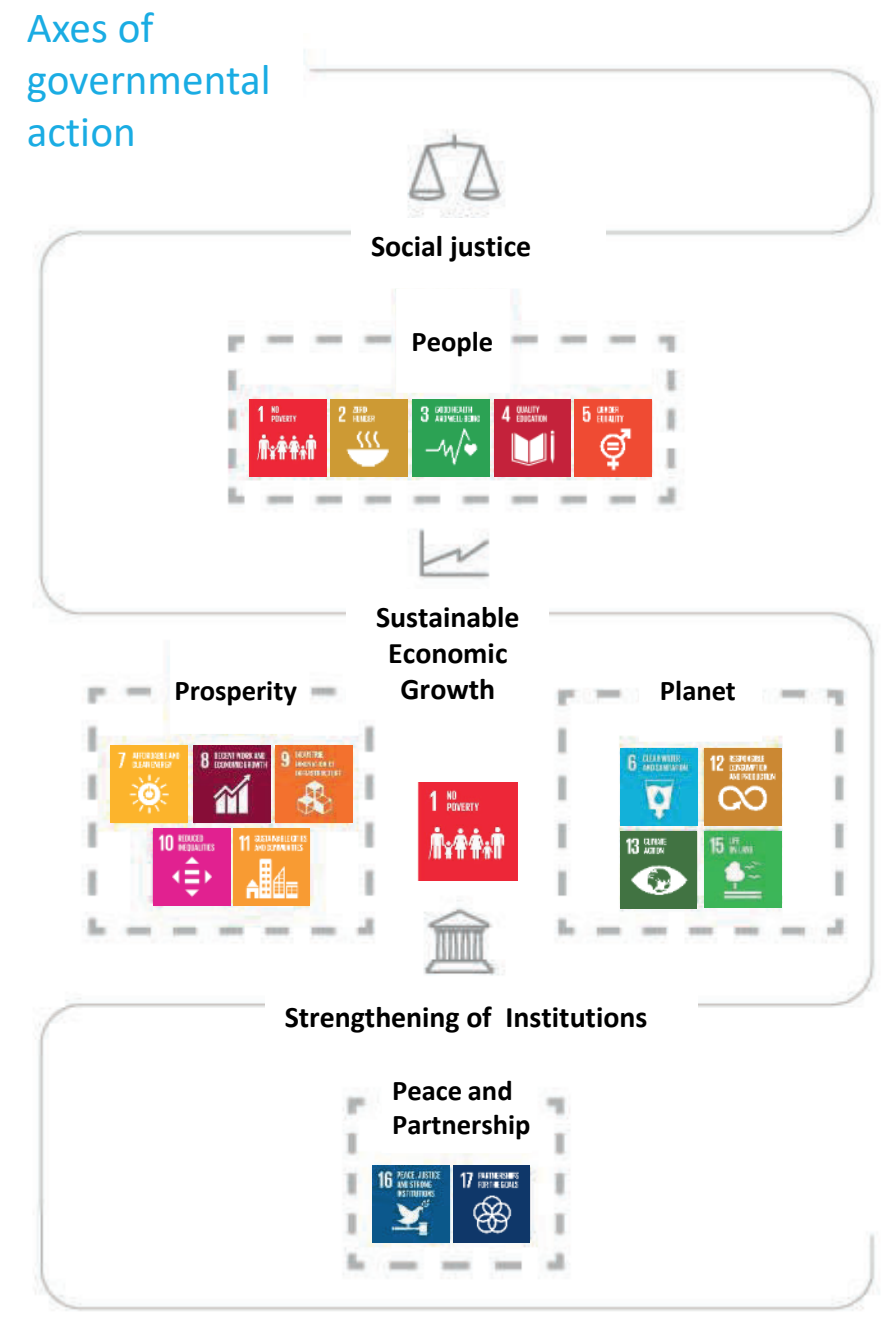

Source: Government of the Province of Córdoba (2017[9]). Government of the Province of Córdoba (2017), Memoria de Gestión Gubernamental 2017 [Government Management Report 2017], https://www.odsargentina.gob.ar/public/documentos/seccion provincias/cordoba/documentos/ memoria_de_gesti\%c3\%b3n_gubernamental_2017_baja.pdf.

The social justice axis and SDG 10 Reduced inequalities are the priority of the provincial government. The province considers SDG 1 No Poverty as the final objective, whose fulfilment depends on the achievement of the remaining SDGs. Among the three axes of governmental action, the social justice axis, therefore, represents the most essential objective and political priority of the government. It aims to ensure the well-being of all people living in the province of Córdoba. It groups SDG 1 No Poverty, SDG 2 Zero Hunger, SDG 3 Good Health and Well-Being, SDG 4 Quality Education and SDG 5 Gender Equality), which are referred to as the People dimension, plus SDG 10 Reduced Inequalities. The sustainable economic growth axis is seen as a means to promote social inclusion through the actions of the various sectors of the economy. It includes the SDGs focusing on Prosperity (SDG 7 Affordable and Clean Energy, SDG 8 Decent Work and Economic Growth, SDG 9 Industry, Innovation and Infrastructure, SDG 11 Sustainable Cities and Communities) and Planet (SDG 6 Clean Water and Sanitation, SDG 12 Responsible Consumption and Production, SDG 13 Climate Action and SDG 15 Life on Land). Finally, the axis on strengthening institutions (SDG 16 Peace, Justice and Strong Institutions and SDG 17 Partnership for the Goals) focuses on promoting dialogue and partnerships to build solid institutions and the establishment of partnerships, which are pivotal to address the challenges of the 2030 Agenda. The province furthermore 
distinguishes between direct goals - objectives that can be directly linked to specific departments of the provincial government - which include SDG 3 Good Health and Well-Being, SDG 4 Quality Education, SDG 6 Clean Water and Sanitation, SDG 7 Affordable and Clean Energy, SDG 8 Decent Work and Economic Growth, SDG 9 Industry, Innovation and Infrastructure, SDG 13 Climate Action and 15 Life on Land - and indirect or transversal goals - objectives that are addressed in a transversal/indirect way such as SDG 2 Zero Hunger, SDG 5 Gender Equality, SDG 10 Reduced Inequalities, SDG 11 Sustainable Cities and Communities, SDG 12 Responsible Consumption and Production, SDG 16 Peace, Justice and Strong Institutions and SDG 17 Partnership for the Goals (Figure 1.3).

\section{Figure 1.3. Categorisation of the different SDGs in the province of Córdoba}

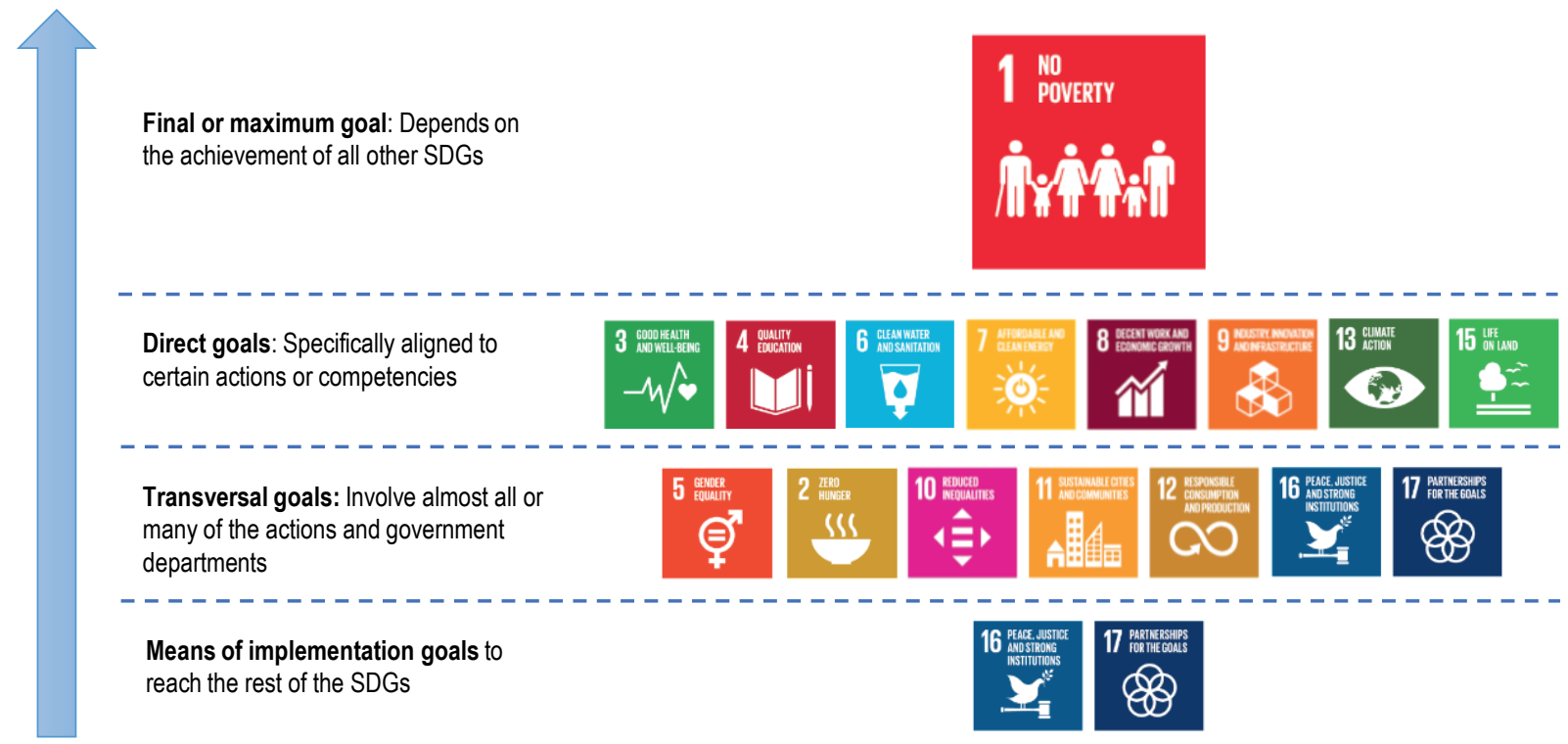

Source: Elaborated by the OECD based on Government of the Province of Córdoba $\left(2019_{[10]}\right)$, Pilot Survey on A Territorial Approach to the Sustainable Development Goals in Córdoba, Argentina.

The province of Córdoba sees the 2030 Agenda as an opportunity to advance and strengthen its management model. Acknowledging the value of the 2030 Agenda for improving the effectiveness of governmental actions, the province of Córdoba works on the implementation of the 2030 Agenda for the following reasons:

- It promotes a management model based on data, indicators and targets, which supports decisionmaking and can result in policies, actions and programmes that can be better measured and, consequently, better oriented to the needs of the territory and people's well-being and living conditions in Córdoba.

- It fosters collaborations, both internally, integrating all the departments that are part of the structure of the government, and externally, generating opportunities for collaboration across levels of government (national, provincial, municipal) and with the private sector, civil society and universities.

- It allows the monitoring of long-term goals and objectives, and promotes accountability and transparency, two points that are very high on the province's agenda.

- It allows to better communicate the actions of the government in an integrated way and aligned with the international agenda. 


\section{Promoting social inclusion in Córdoba: From well-being to the SDGs}

For the province of Córdoba, the current efforts to localise the SDGs build on the previous work on regional well-being and sustainable development. The work on the localisation of the SDGs is a follow-up to the OECD Territorial Review of Córdoba (2016[2]) (Box 1.1) and the policy dialogue on regional well-being and sustainable development published in 2019, How's Life in the Province of Córdoba, Argentina? (2019 $\left.{ }_{[3]}\right)$. The latter has a strong focus on social inclusion and quality of life and entails a large component about the production of regional indicators to measure well-being. As a next step, the province decided to develop a matrix to identify and measure the synergies and the trade-offs among the social and the economic and environmental SDGs. This matrix allows revealing the drivers of social inclusion in Córdoba as well as to develop a vision for the province towards 2030. The process is described more in-depth in Chapter 3 . As Table 1.2 highlights, there are strong linkages between the three axes of governmental action of the province of Córdoba, the OECD well-being framework and the SDGs.

Table 1.2. Córdoba's development priorities, OECD regional well-being framework dimensions and the SDGs

\begin{tabular}{|c|c|c|c|}
\hline Development priority & Description & $\begin{array}{l}\text { OECD well-being } \\
\text { dimensions }\end{array}$ & Related SDGs \\
\hline Social justice & $\begin{array}{l}\text { Social justice is the essential aspect of the } \\
\text { provincial management approach on which many } \\
\text { of the government's public policies are based. The } \\
\text { initiatives, programmes and plans included in this } \\
\text { priority area are people-focused, concentrating } \\
\text { especially on helping families in Córdoba to } \\
\text { develop their full potential with dignity and equal } \\
\text { opportunities. }\end{array}$ & $\begin{array}{l}\text { Income } \\
\text { Housing } \\
\text { Education } \\
\text { Health } \\
\text { Personal security } \\
\text { Life satisfaction }\end{array}$ & $\begin{array}{l}\text { Family/People } \\
\text { SDG 1: No poverty } \\
\text { SDG 2: Zero hunger } \\
\text { SDG 3: Good health and well-being } \\
\text { SDG 4: Quality education } \\
\text { SDG 5: Gender equality } \\
\text { SDG 10: Reduced inequalities }\end{array}$ \\
\hline $\begin{array}{l}\text { Sustainable economic } \\
\text { growth }\end{array}$ & $\begin{array}{l}\text { Sustainable economic growth is how the province } \\
\text { promotes the development and well-being of all } \\
\text { Cordovan people. The focus is put on initiatives, } \\
\text { programmes and plans designed to increase } \\
\text { prosperity while taking care of the environment. } \\
\text { This shall be achieved by strengthening } \\
\text { infrastructure to enable productive and responsible } \\
\text { development, underpinned by the promotion of } \\
\text { innovation and the generation of decent work as } \\
\text { well as an environment-friendly development that } \\
\text { promotes the use of clean and renewable energies. }\end{array}$ & $\begin{array}{l}\text { Jobs } \\
\text { Access to services } \\
\text { Environment } \\
\text { Work-life balance }\end{array}$ & $\begin{array}{l}\text { Planet } \\
\text { SDG 6: Clean water and sanitation } \\
\text { SDG 12: Responsible production and } \\
\text { consumption } \\
\text { SDG 13: Climate action } \\
\text { SDG 15: Life on land } \\
\text { Prosperity } \\
\text { SDG 7: Affordable and clean energy } \\
\text { SDG 8: Decent work and economic } \\
\text { growth } \\
\text { SDG 9: Industry, innovation and } \\
\text { infrastructure } \\
\text { SDG 11: Sustainable cities and } \\
\text { communities }\end{array}$ \\
\hline $\begin{array}{l}\text { Strengthening } \\
\text { institutions }\end{array}$ & $\begin{array}{l}\text { This development priority creates the conditions } \\
\text { needed to boost the impact of the government's } \\
\text { work and improve public institutions. This policy } \\
\text { aim is to involve all plans and programmes that } \\
\text { promote open, dynamic and intelligent institutions. } \\
\text { In that way, the strengthening of institutional } \\
\text { performance allows for an increase in transparency } \\
\text { and the promotion of accountability, including all } \\
\text { initiatives in the area of citizen security and justice. }\end{array}$ & $\begin{array}{l}\text { Civic engagement } \\
\text { and governance and } \\
\text { social support }\end{array}$ & $\begin{array}{l}\text { Partnerships and peace } \\
\text { SDG 16: Peace, justice and strong } \\
\text { institutions } \\
\text { SDG 17: Partnerships for the goals }\end{array}$ \\
\hline
\end{tabular}

Source: OECD elaboration based on Government of the Province of Córdoba $\left(2019_{[1]}\right)$, Memoria de Géstion Gubernamental 2018 [Government Management Report 2018\}, https://datosgestionabierta.cba.gov.ar/dataset/03dfbf6c-475f-4906-bf84-c6ee69dc3121/resource/6e068945-ad0e4d28-bf50-b7a4c6c8ebb0/download/memoria-de-gestion-gubernamental-2018.pdf. 


\section{Box 1.1. OECD Territorial Review of Córdoba, 2016}

\section{Key findings and recommendations}

In 2016, the OECD engaged in a year-long policy dialogue with more than 100 stakeholders from the public, private and non-profit sectors in the province of Córdoba, Argentina. This process resulted in a final report assessing the province's regional development policy and provides recommendations on how to address various bottlenecks detected through the review.

One of the key challenges highlighted is the turning point of Córdoba's economic development in 2009, which marked the end of a period of strong economic recovery and significant improvements in the quality of life for its citizens after the Argentinian crisis in 2001-02. Córdoba saw a drop in provincial GDP growth by $3.7 \%$, caused by a downturn in regional and global markets, as well as a decline in commodity prices, which negatively affected the province's commodity- and export-driven economy (largely dominated by agriculture and food industry, metal-mechanic manufacturing, ICT and tourism). This revealed the necessity to upgrade and better connect its productive sectors and pointed to the need for a formalised regional development strategy, including economic diversification, upgrading of global value chains and sustained well-being.

Other challenges identified in the review were the lack of availability of and access to reliable data and statistics and thus the need for trustworthy data to guide decision-making related to the design and implementation of any regional strategy (in particular in a context of unreliable national statistics). Regional competitiveness and productivity were found to be hindered by several factors, including an unexploited potential in infrastructure, insufficient access to finance for the private sector and deficiencies in education and innovation. Finally, governance issues around transparency and accountability, including personalism and one-way communication with citizens, as well as insufficient incentives for autonomous municipalities to collaborate meant that the province is not able to fully leverage its development potential.

To address the above, the following headline recommendations detailed in the report were:

- Development of a full-fledged regional development strategy based on a medium- to long-term vision for the province.

- Modernising and strengthening the provincial statistical infrastructure.

- Designing and implementing an integrated infrastructure development strategy.

- Facilitating small- and medium-sized enterprises' (SMEs) access to financing.

- Strengthening the quality of secondary and vocational education.

- Designing and implementing a regional innovation strategy to modernise productive activities towards value-added niches.

- Ensuring coherence and co-ordination in achieving Córdoba's strategic objectives across ministries and public agencies, and between levels of government.

- Adopting a functional approach to define the boundaries of the metropolitan area of Greater Córdoba based on where people work and live rather than administrate perimeters.

- Improving monitoring and performance management practices.

- Strengthening multi-level governance.

- Fostering two-way citizen engagement for better transparency, accountability and service provision.

Source: OECD (2016[2]), OECD Territorial Reviews: Córdoba, Argentina, https://doi.org/10.1787/9789264262201-en. 


\section{Box 1.2. Why a territorial approach to the SDGs?}

The 2030 Agenda was not designed specifically for cities and regions but they play a crucial role to achieve the SDGs. The OECD estimates that at least 105 of the 169 targets underlying the 17 SDGs will not be reached without proper engagement and co-ordination with local and regional governments, as cities and regions have core responsibilities that are central to sustainable development and wellbeing (e.g. water services, housing or transport). They also discharge a significant share of public investment (60\% in OECD countries), which is critical to channel the required funding to meet the SDGs. Although the SDGs provide a global framework, the opportunities and challenges for sustainable development vary significantly across and within countries, regions and cities. However, they are also an integral part of the solution as the varying nature of sustainable development challenges therefore calls for place-based solutions, tailored to territorial specificities, needs and capacities. Place-based policies incorporate a set of co-ordinated actions specifically designed for a particular city or region and stress the need to shift from a sectoral to a multi-sectoral approach, from one-size-fits-all to contextspecific measures and from a top-down to a bottom-up approach to policymaking. Based on the idea of policy co-ordination across sectors and multi-level governance, whereby all levels of government and non-state actors should play a role in the policy process, they consider and analyse functional territories, build on the endogenous development potential of each territory and use a wide range of actions (OECD, 2019[11]).

The SDGs can help to advance conceptually the shift towards a new regional development policy paradigm and provide a framework to implement it, as:

- The 2030 Agenda provides a long-term vision for strategies and policies with a common milestone in 2030, while acknowledging that targeted action is needed in different places since their exposure to challenges and risk vary widely as does their capacity to cope with them.

- The interconnected SDG framework allows the promotion of policy complementarities and the management of trade-offs across goals. Indeed, the SDGs enable policymakers to address the social, economic and environmental dimensions of sustainable development concomitantly, building on the synergies and taking interlinkages into account.

- The SDGs allow to better implement the concept of functional territories, a common framework that neighbouring municipalities can use to strengthen collaborations and co-ordinate actions.

- The SDGs can be used to promote multi-level governance and partnerships, including the engagement of various stakeholders in the policymaking process.

\section{The OECD analytical framework for A Territorial Approach to the SDGs}

The OECD has identified four critical megatrends influencing the achievement of the SDGs in cities and regions: i) demographic changes, in particular urbanisation, ageing and migration; ii) climate change and the need to transition to a low-carbon economy; iii) technological changes, such as digitalisation and the emergence of artificial intelligence; and iv) globalisation and the related geography of discontent. The SDGs provide a framework for cities and regions to respond systemically to such global megatrends. The proposed OECD framework foresees three key areas, policies and strategies, actors and tools, for cities and regions to implement a territorial approach to the SDGs.

\section{Policies and strategies}

Cities and regions can use the SDGs as a means to shift from a sectoral to a multi-sectoral approach, both in the design and implementation of their policies. The SDGs can help to bring various departments of a local administration together to strengthen the collaboration in policy implementation. Regional policy aims to effectively address the diversity of economic, social, demographic, institutional and geographic conditions across cities and regions. It also ensures that sectoral policies are co-ordinated 
with each other and meet the specific needs of different regions and provides the tools that traditional structural policies often lack in order to address region-specific factors that cause economic and social stagnation (OECD, 2019[11]).

\section{Tools}

The effective implementation of a territorial approach to the SDGs implies the combined use of a variety of tools. These span from a solid multi-level governance system to global and context-specific data for evidence-based policies. They also consist of combining functional and administrative approaches to address territorial challenges and opportunities beyond borders, as well as investment and incentives, in particular for the private sector to contribute. Multi-level governance represents a key tool to promote vertical co-ordination (across levels of government) and horizontal co-ordination (across ministries and departments) - both within the local, regional and national governments and between the government and other key stakeholders. National governments can also use the SDGs as a framework to promote policy coherence across levels of government, align priorities and rethink sustainable development through a bottom-up approach.

\section{Actors}

A participatory policymaking and bottom-up process is one of the core elements of a territorial approach to the SDGs. Shifting from a top-down and hierarchical to a bottom-up and participatory approach to policymaking and implementation is key for the achievement of the SDGs. The 2030 Agenda requires a more transparent and inclusive model that involves the public as well as non-state actors to co-design and jointly implement local development strategies and policies. The SDGs provide cities and regions with a tool to effectively engage in multi-stakeholder dialogues with actors from the private sector, civil society, as well as schools and academia.

\section{Figure 1.4. The OECD analytical framework for A Territorial Approach to the SDGs}

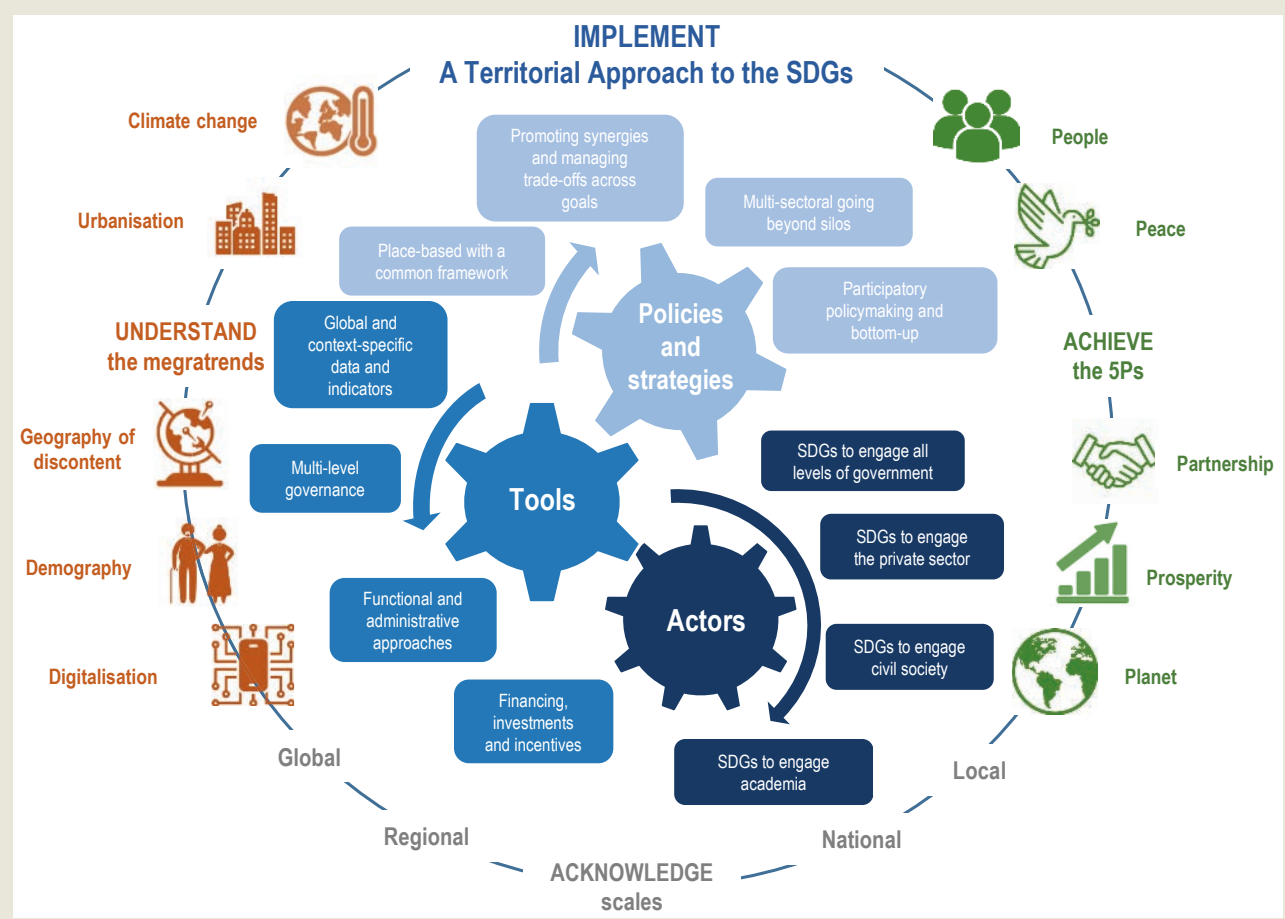

Source (figure): OECD (2020[12]), A Territorial Approach to the Sustainable Development Goals: Synthesis Report, https://doi.org/10.1787/ e86fa715-en.

Source (box): OECD (2019[11]), OECD Regional Outlook 2019: Leveraging Megatrends for Cities and Rural Areas, https://dx.doi.org/10.17 87/9789264312838-en. 


\section{References}

General Directorate of Statistics and Censuses (2020), Producto Bruto Regional - Informe provincial y departamentales 2017 [Gross Regional Product - Provincial and Departmental Report 2017], Province of Córdoba, https://datosestadistica.cba.gov.ar/dataset/productobruto-regional (accessed on 13 August 2020).

General Directorate of Statistics and Censuses (2019), Exportaciones de la Provincia de Córdoba Años 2008-2017 [Exports of the Province of Córdoba Years 2008-2017], Province of Córdoba, https://datosestadistica.cba.gov.ar/dataset/comercio-exterior (accessed on 13 August 2020).

General Directorate of Statistics and Censuses (2019), Importaciones de la Provincia de Córdoba Años 2008 - 2017 [Imports of the Province of Córdoba Years 2008-2017], Province of Córdoba, https://datosestadistica.cba.gov.ar/dataset/comercio-exterior (accessed on 13 August 2020).

Government of the Province of Córdoba (2019), Memoria de Géstion Gubernamental 2018 [Government Management Report 2018\}, https://datosgestionabierta.cba.gov.ar/dataset/03dfbf6c-475f-4906-bf84c6ee69dc3121/resource/6e068945-ad0e-4d28-bf50-b7a4c6c8ebb0/download/memoria-degestion-gubernamental-2018.pdf.

Government of the Province of Córdoba (2019), Pilot Survey on A Territorial Approach to the Sustainable Development Goals in Córdoba, Argentina.

Government of the Province of Córdoba (2017), Memoria de Gestión Gubernamental 2017 [Government Management Report 2017], https://www.odsargentina.gob.ar/public/documentos/seccion provincias/cordoba/documentos Imemoria de gesti\%c3\%b3n gubernamental 2017 baja.pdf.

INDEC (2010), National Census on Population, Households and Housing, https://www.indec.gob.ar/indec/web/Nivel4- (accessed on 13 August 2020).

OECD (2020), A Territorial Approach to the Sustainable Development Goals: Synthesis report, OECD Urban Policy Reviews, OECD Publishing, Paris, https://dx.doi.org/10.1787/e86fa715en.

OECD (2019), How's Life in the Province of Córdoba, Argentina?, OECD Publishing, Paris, https://dx.doi.org/10.1787/97f189b1-en.

OECD (2019), OECD Regional Outlook 2019: Leveraging Megatrends for Cities and Rural Areas, OECD Publishing, Paris, https://dx.doi.org/10.1787/9789264312838-en.

OECD (2016), OECD Territorial Reviews: Córdoba, Argentina, OECD Territorial Reviews, OECD Publishing, Paris, https://dx.doi.org/10.1787/9789264262201-en.

Oxford Business Group (2018), The Report - Argentina 2018 Córdoba, https://oxfordbusinessgroup.com/sites/default/files/booklets/2018 argentina cordoba booklet .pdf. 

2 Sustainable development

\section{challenges and opportunities in Córdoba, Argentina}

The province of Córdoba achieved a performance higher than the average of Latin American regions in several Sustainable Development Goals' (SDGs) indicators related to health, education, air pollution and Internet connectivity, while showing room for improvement in several environmental, housing and safety indicators. Córdoba furthermore exhibits low levels of confidence in the judicial system and political institutions. Particularly positive results for Córdoba compared to OECD regions include low inequalities in gross household income and significant availability of cropland areas to ensure food security. In order to measure progress on the 2030 Agenda, the province has developed a list of indicators taking into account the regional circumstances of Córdoba, which consists of 115 indicators covering all 17 SDGs. 


\section{The importance of data-driven policies: Córdoba's work on SDGs indicators}

Córdoba has been actively working on the development of socio-demographic indicators since the 2010 Millennium Development Goals (MDGs). In November 2005, the government together with the Presidency of the Nation and the National Council for Coordination of Social Policies (Consejo Nacional de Coordinación de Politicas Sociales, CNCPS) signed a collaboration agreement in order to work on the definition and development of socio-economic indicators, and the monitoring and implementation of social programmes and policies. It also defined targets to be achieved by 2015 in relation to relevant MDGs. In 2006, the province of Córdoba presented a report with indicators based on the MDGs. The work on the MDGs continued internally without an official publication until 2016 when the province published its first Government Management Report.

The province of Córdoba prioritises monitoring indicators that are most relevant in the context of the province's prioritised SDG targets. The exercise of defining, prioritising and measuring indicators is led by the Secretariat for Institutional Strengthening (Secretaría de Fortalecimiento Institucional, SFI). The different government departments involved in the work on the 2030 Agenda are also active in the InterMinisterial SDGs Board, which provides a platform to share, discuss and validate information and data required for the provincial indicator framework. The work on indicators is carried out in collaboration with the provincial General Directorate of Statistics and Censuses (Dirección General de Estadística y Censos, DGEyC), which leads the methodological statistical work. Using the prioritised SDGs as a basis, the SFI and DGEyC carried out an analysis of different indicator sets to find those that could be used for Córdoba: i) indicators proposed by the United Nations and the World Bank; ii) indicators adopted at the national level by the Argentinian government; iii) place-based indicators developed by the OECD on regional well-being; and iv) management indicators used by the various departments. On the basis of these analysis and databases, a list of indicators taking into account the regional circumstances of Córdoba was produced. The final list of indicators consists of 115 indicators covering all 17 SDGs; 62 of them measure targets of the priority SDGs of the province - SDGs 1, 2, 3, 4, 5 and 10 .

Around 30 of the prioritised target indicators can be measured through the regional well-being survey that had been carried out directly by the DGEyC and is updated twice a year. While this is beneficial in terms of leveraging existing resources and not depending on external organisations to obtain data, the survey can lead to difficulties when making comparisons with other provinces in Argentina, since it produces data for four large urban agglomerations (Gran Córdoba, Río Cuarto-Las Higueras, San Francisco and Villa María-Villa Nueva) rather than provincial-level data. In terms of data available from national sources, in Argentina, the National Institute of Statistics and Censuses (Instituto Nacional de Estadística y Censos, INDEC) is responsible for official statistical activities. Data from surveys (e.g. the 2010 Census, the National Survey of Risk Factors, the Survey of Unpaid Work and Use of Time and the Permanent Enlarged Household Survey), co-ordinated by the INDEC, allow for obtaining comparable indicators between provinces. Some of the challenges related to the development of indicators for data availability experienced by Córdoba include issues of up-to-date data availability as well as limited access to administrative records that could be helpful to fill data gaps. In addition, collecting data on the environmental SDGs turned out to be particularly challenging.

\section{Measuring the distance to the SDGs in Córdoba, Argentina}

This section assesses Córdoba's performance towards achieving the SDGs based on the OECD localised indicator framework for the SDGs. The assessment follows the structure of the five critical dimensions of the 2030 Agenda, namely People, Prosperity, Planet, Peace and Partnerships (Figure 2.1). It is based on a selection of 36 indicators covering key aspects of 13 out of the 17 SDGs ${ }^{1}$ - including indicators from the OECD report How's Life in the Province of Córdoba, Argentina? (OECD, 2019 ${ }_{[1]}$ ) (see Table 2.1). Further information on the methodology of the assessment can be found in Box 2.1. It is important to highlight that 
while some indicators are representative of the whole province of Córdoba, some others correspond only to the average performance of four main agglomerations of the Province (Figure 2.2): Gran Córdoba, Rio Cuerta-Las Higueras, San Francisco and Villa María-Villa Nueva. In such cases, indicators of the four agglomerations are used as a proxy for the entire province when data at the provincial level were not available. ${ }^{2}$ The assessment includes comparisons with regions of OECD countries, as well as with a selection of regions in Latin American countries (Argentina, Brazil, Chile, Colombia, Mexico and Peru). ${ }^{3}$

Figure 2.1. The 17 Sustainable Development Goals

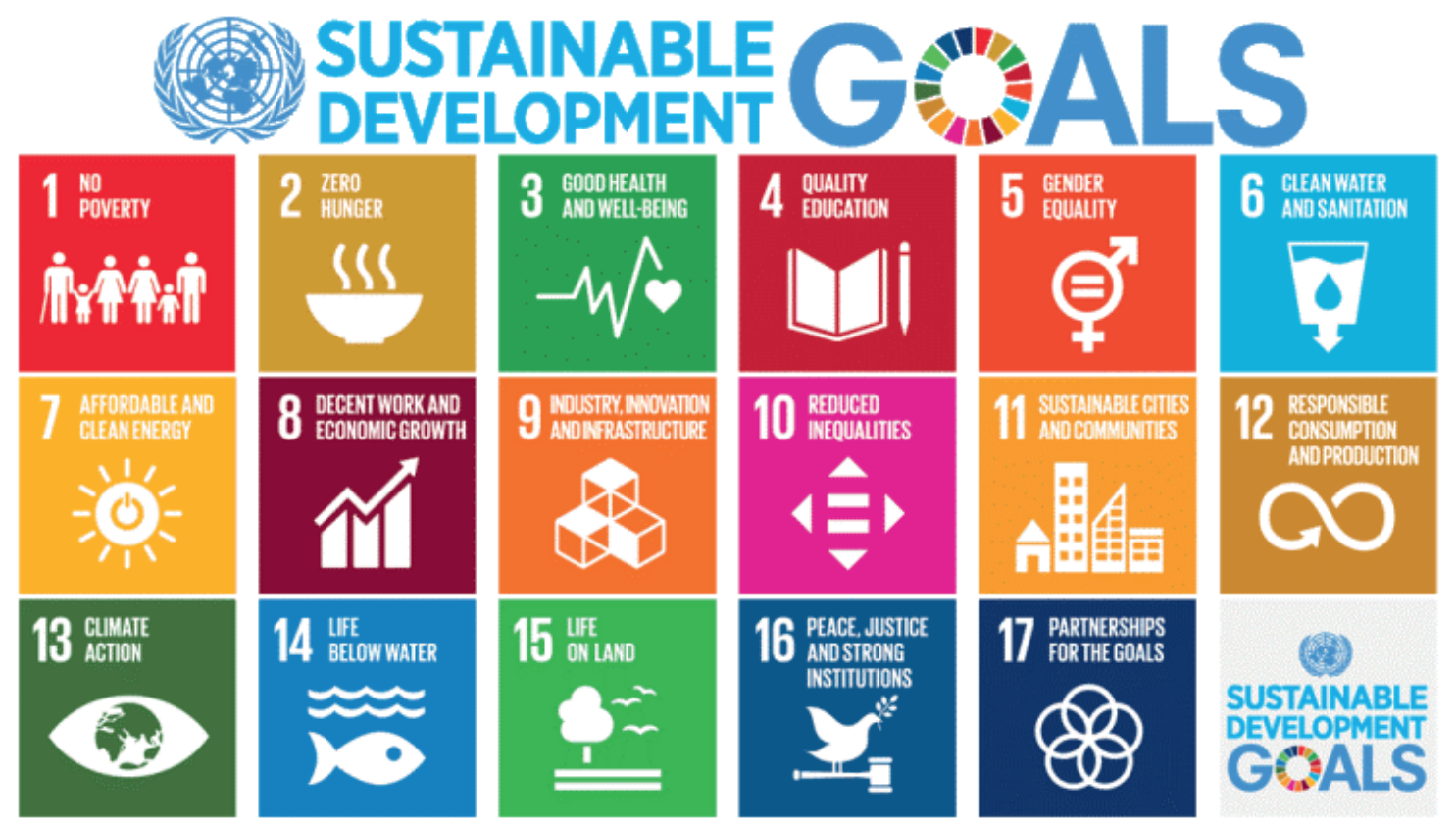

Source: UN (2020[2]), Sustainable Development Goals, United Nations Sustainable Development Knowledge Platform, https://sustainabledevel opment.un.org/?menu=1300.

\section{Box 2.1. OECD methodology for measuring cities' and regions' distance to the SDGs}

The OECD has developed a framework to localise the SDG targets and indicators and measure the distance of regions and cities to reaching each of the 17 SDGs. This consensual, comparable and standardised framework allows to benchmark performances within countries and across regions and cities to support public action across levels of government.

In the context of OECD countries, around 105 out of the 169 SDG targets have been identified as very relevant for regions and cities. Through an extensive literature review and expert consultation, the 169 SDGs targets from the United Nations (UN) indicator framework have been classified by their level of relevance for subnational levels of government (place-relevant) and advanced economies (OECD relevant). Subsequently, a subset of these SDG targets has been selected on the basis of its applicability to the context and specificities of OECD countries. The result is a selection of 105 SDG targets and 135 indicators for OECD regions and cities (also referred to as the "subnational SDG targets").

With its 135 indicators, the OECD localised framework covers at least 1 aspect of each of the 17 SDGs for both regions and cities. Nevertheless, the coverage in terms of indicators and targets is higher for regions than for cities. Currently, 56 indicators (covering $32 \%$ of the subnational SDG targets) are 
available for cities with more than 250000 inhabitants in OECD and partner countries. Although the set of indicators aims to cover the broad spectrum of all 17 SDGs, the coverage in terms of indicators also varies widely across SDGs.

In order to evaluate the achievements of a city or region on the SDGs, the OECD localised framework defines end values to shed light on the global trends in OECD regions and cities towards the SDGs, based on available indicators and to provide technical guidance for governments on a possible way to use the SDG indicator framework as a tool to advance local development plans and sustain evidencebased policies. By defining end values for 2030 , regions and cities can assess where they stand today and seize how much distance they have to travel in order to reach the intended end value. When they are not inferable from the UN framework, the OECD defines end values for indicators based on the knowledge of experts in the field or based on the best performance of regions and cities in that indicator. The OECD localised indicator framework attributes end values to $88 \%$ of its indicators, of which $65 \%$ are defined using the criteria of "best performers". The framework also normalises the SDG indicators from 0 to 100 - where 100 is the suggested end value of an indicator to be achieved by 2030 - and aggregates headline indicators that belong to the same SDG to provide an index score towards each of the 17 SDGs. The distance to the target or goal is the number of units the index needs to travel to reach the maximal score of 100.

Source: OECD (2020[3]), A Territorial Approach to the Sustainable Development Goals: Synthesis Report, https://doi.org/10.1787/e86fa715en; OECD (2020[4]], Measuring the Distance to the SDGs in Regions and Cities (visualisation tool), http://www.oecd-local-sdgs.org.

\section{Box 2.2. Limitations and considerations of subnational indicators from Gallup World Poll}

This chapter uses indicators from the OECD localised framework to provide a comparative overview of the province of Córdoba's progress towards the SDGs. While the OECD indicator framework prioritises indicators from official sources (i.e. country's statistical offices), unofficial or unconventional data sources - such as micro data from surveys or gridded data from satellite imagery - are used for those SDGs with important data gaps at the subnational level (OECD, 2020[3]).

Gallup World Poll (Gallup) is one of the non-official data sources used in this report. Since the yearly samples collected by Gallup are by construction intended to be representative at the national level, the OECD carried out exploratory statistical analysis to estimate subnational indicators. One of the approaches consisted in increasing sample sizes by pooling several waves of the survey together (which reduces confidence intervals for multi-annual indicators at the expense of not having yearly data). In previous work, the OECD documented that in most cases the distribution of regional population by age and gender (based on censuses) was not statistically different from the distribution of the sample in Gallup. In addition, the studied Gallup indicators (e.g. life satisfaction) were highly correlated with indicators coming from other sources with larger and representative regional samples such as EU SILC for the European Union, or surveys carried out by the Office for National Statistics in the United Kingdom and the National Institute of Statistics (Instituto Nazionale di Statistica) in Italy (Brezzi and Diaz Ramirez, 2016[5]).

Nevertheless, despite the above methodological considerations, the Gallup-based indicators for the province of Córdoba (with a multi-annual sample of around 700 observations per indicator) might be less precise than the other indicators and could be considered as more approximative. As a way of comparison, the score on life satisfaction from the DGEyC's Well-Being Survey (Encuesta de Bienestar, semester 2, 2018) of 7.4 (from 0 to 10) for the largest four urban agglomerations of Córdoba (OECD, 
$\left.2019_{[1]}\right)$ is one point above the estimated value for the whole province (6.4) when using Gallup World Poll, which appears to be roughly in line.

\section{About Gallup World Poll}

Gallup World Poll is a repeated cross-sectional survey covering more than 150 countries and areas in the world. Using its global network of researchers and political scientists, Gallup develops and collects key data related to law and order, food and shelter, job creation, migration, financial life, personal health, civic engagement and subjective well-being, as well as opinions about national institutions, corruption, youth development, community, diversity and optimism. Every year, Gallup surveys around 1000 individuals in each country or area. Surveys are conducted face-to-face or via telephone depending on the country, and questions are translated to the main languages spoken in the country (Gallup World Poll, 2020[6]).

Source: OECD (2020[3]), A Territorial Approach to the Sustainable Development Goals: Synthesis Report, https://doi.org/10.1787/e86fa715en; Brezzi, M. and M. Diaz Ramirez (2016 $\left.{ }_{[5]}\right)$, "Building subjective well-being indicators at the subnational level: A preliminary assessment in OECD regions", OECD Regional Development Working Papers, 2016/03, OECD Publishing, Paris. http://dx.doi.org/10.1787/5jm2hhcjftvh-en; OECD (2019 $\left[{ }_{[1]}\right)$, How's Life in the Province of Córdoba, Argentina?, OECD Publishing, Paris, https://doi.org/10.1787/97f189b1-en., Gallup World Poll (2020[6]), Worldwide Research Methodology and Codebook.

Overall, Córdoba's performance towards achieving the SDGs is below the average of OECD regions in the majority of the SDG targets and indicators; however the province outperforms Latin American peers in a number of indicators. Compared to the average of OECD regions, particularly positive results are the province's low gross income inequality and the availability of cropland areas to ensure food security. Córdoba's achievements are similar to those of OECD regions regarding child mortality (SDG 3), satisfaction with life as a whole (SDG 3) and the perception of Córdoba as a good place to live for gay or lesbian people (SDG 16). In contrast, challenges can be found across several dimensions of the 2030 Agenda and include high levels of air pollution (SDG 11), low levels of satisfaction with housing affordability (SDG 11), safety (SDG 16) and a low level of trust and confidence in the judicial system and political institutions (SDG 16).

Although Cordoba is lagging behind the average of OECD regions, the province tends to have better outcomes than the average of Latin American regions in several SDGs indicators. The areas where Córdoba outperforms many of its peer regions, from Argentina, Brazil, Chile, Colombia, Mexico to Peru, include indicators such as mortality rates (SDG 3), respect towards women (SDG 5), the share of secondary education degrees among the labour force (SDG 9), air pollution levels (SDG 11) and the share of the population with Internet access (SDG 17). Nevertheless, Córdoba has some progress to make to catch up with the average of Latin American regions in indicators across several SDGs including satisfaction rates with efforts to deal with poverty (SDG 1), the gender gap in unemployment (SDG 5), the loss of water bodies (SDG 6), satisfaction with efforts to protect the environment (SDG 13) and loss of tree cover (SDG 15). In all these indicators, Córdoba belongs to the bottom $20 \%$ of regions in Latin America. 
Figure 2.2. Map of the province of Córdoba and its four main agglomerations

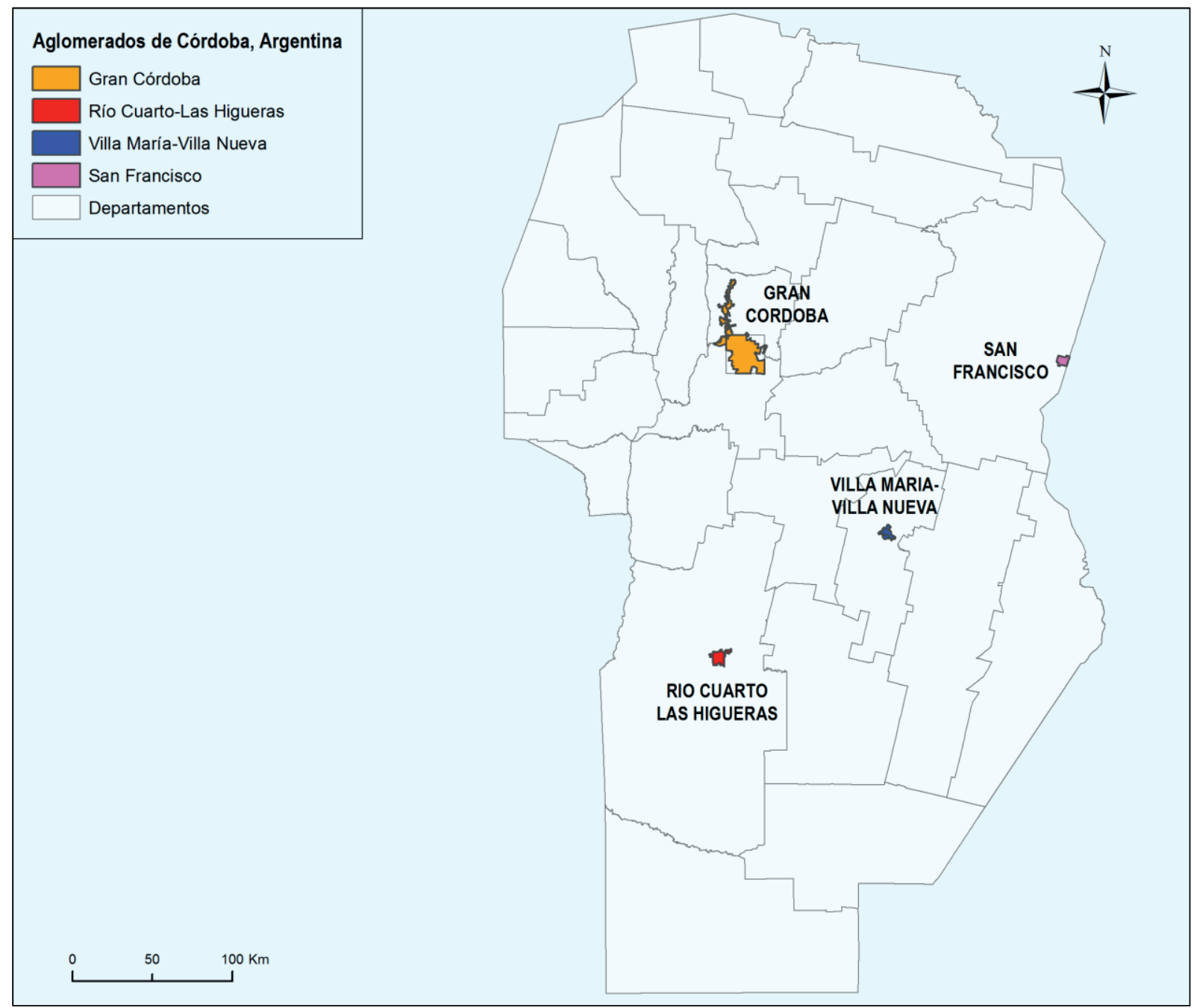

Source: OECD (2019[1]), How's Life in the Province of Córdoba, Argentina?, https://doi.org/10.1787/97f189b1-en.

Table 2.1. Indicators from the OECD Regional Well-Being framework used to complement the assessment of the province of Córdoba, Argentina

\begin{tabular}{|c|c|c|c|}
\hline SDG & Indicator & $\begin{array}{l}\text { Geographic area } \\
\text { covered }\end{array}$ & Data source \\
\hline thithit & $\begin{array}{l}\text { Gross household income (before taxes and transfers) adjusted per unit of } \\
\text { consumption ("equivalised") }\end{array}$ & 4 main agglomerations & $\begin{array}{c}\text { Encuesta de Bienestar } \\
\text { [Córdoba's Well-Being } \\
\text { Survey] }\end{array}$ \\
\hline$€$ & Percentage of people with gross income below $60 \%$ of the median & 4 main agglomerations & $\begin{array}{c}\text { Encuesta de Bienestar } \\
\text { [Córdoba's Well-Being } \\
\text { Survey] }\end{array}$ \\
\hline$€$ & Gini index of gross income ( 0 for perfect equality, 1 for perfect inequality) & 4 main agglomerations & $\begin{array}{c}\text { Encuesta de Bienestar } \\
\text { [Córdoba's Well-Being } \\
\text { Survey] }\end{array}$ \\
\hline $3=1-1$ & $\begin{array}{l}\text { Percentage of people (aged } 18 \text { or more) who have at least one friend they can } \\
\text { rely on if needed }\end{array}$ & 4 main agglomerations & $\begin{array}{c}\text { Encuesta de Bienestar } \\
\text { [Córdoba's Well-Being } \\
\text { Survey] }\end{array}$ \\
\hline
\end{tabular}




\begin{tabular}{c|l|c|c}
\hline SDG & \multicolumn{1}{|c|}{ Indicator } & $\begin{array}{c}\text { Geographic area } \\
\text { covered }\end{array}$ & Data source \\
\hline$\sqrt{*-1}$ & $\begin{array}{l}\text { Percentage of total household gross income spent on rent (only households } \\
\text { that rent) }\end{array}$ & 4 main agglomerations & $\begin{array}{c}\text { Encuesta de Bienestar } \\
\text { [Córdoba's Well-Being } \\
\text { Survey] }\end{array}$ \\
\hline
\end{tabular}

OECD (2019[1] $)$, How's Life in the Province of Córdoba, Argentina?, OECD Publishing, Paris, https://doi.org/10.1787/97f189b1-en.

\section{People: Córdoba's performance on health and gender equality is above the average of Latin American regions but below the OECD average}

One out of five people in Córdoba is satisfied with the government's efforts to deal with poverty. SDG 1 aims to "end poverty in all its forms everywhere". National and subnational governments are key actors on the pathway to achieve that goal. In the province of Córdoba, the population's satisfaction with the government's efforts to deal with poverty was around $21 \%$ between 2008 and 2018 . This value is lower than the average of OECD regions (37\%). Overall, $90 \%$ of OECD regions have a higher satisfaction rate. It is also among the lowest satisfaction rates of regions in Latin America. Only 2 out of 137 regions in Argentina, Brazil, Chile, Colombia, Mexico and Peru registered lower satisfaction rates with the government's efforts to deal with poverty between 2008 and 2018. Consequently, the satisfaction rate with the government's efforts to deal with poverty in Córdoba also remains below the national average of Argentina (32\%) (see Box 2.2 for methodological limitations of Gallup data).

Gross income levels in Córdoba's four main agglomerations are above its Latin American peer regions but below the OECD average, while the gross income distribution is a key strength of the four agglomerations. Another target of SDG 1 is to eradicate extreme poverty, which is measured as people living on less than USD 1.25 a day. Using the definition of household gross income per unit of consumption (or household equivalised income), the average annual household income in the province's main agglomerations was USD 12756 PPP (at 2010 prices) in 2018. This value is equivalent to $52 \%$ of the average of OECD regions and lower than in $76 \%$ of OECD regions. In the Latin American context, however, the household gross equivalised income of Córdoba's agglomerations is above the levels displayed in most (85\%) of the regions of Chile and Mexico. Only 7 regions in Chile display higher gross incomes than Córdoba's agglomerations. Income levels are an important factor for the targets of SDG 11 related the affordability of housing and housing conditions, which is one of Córdoba's main challenges (see below).

Table 2.2. OECD indicators used to assess the dimension People in Córdoba

\begin{tabular}{|c|c|c|c|}
\hline SDG & Indicator & Geographic area covered & Data source \\
\hline \multirow[t]{2}{*}{ iniming } & $\begin{array}{l}\text { Percentage of the population satisfied with efforts to deal } \\
\text { with poverty }\end{array}$ & Province of Córdoba & $\begin{array}{l}\text { OECD based on Gallup World Poll } \\
\qquad(2019)\end{array}$ \\
\hline & Rooms per person & 4 main agglomerations & $\begin{array}{c}\text { Encuesta de Bienestar [Córdoba's Well- } \\
\text { Being Survey] }\end{array}$ \\
\hline \multirow{2}{*}{$2 \pm$} & Cropland as a percentage of the total area in 2019 & Province of Córdoba & OECD Environment Database \\
\hline & $\begin{array}{l}\text { Change in cropland (from } 1992 \text { to 2019, percentage } \\
\text { points) }\end{array}$ & Province of Córdoba & OECD Environment Database \\
\hline \multirow[t]{4}{*}{ 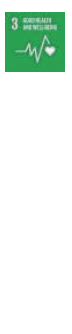 } & $\begin{array}{l}\text { Infant mortality rate (number of deaths of children 1- } \\
\text { year-old or younger per } 1000 \text { live births) }\end{array}$ & Province of Córdoba & $\begin{array}{l}\text { Ministry of Health of the province of } \\
\text { Córdoba }\end{array}$ \\
\hline & Mortality rates for the population $0-4$ years old & Province of Córdoba & $\begin{array}{l}\text { Ministry of Health of the province of } \\
\text { Córdoba }\end{array}$ \\
\hline & Life expectancy at birth & 4 main agglomerations & $\begin{array}{c}\text { Encuesta de Bienestar [Córdoba's Well- } \\
\text { Being Survey] }\end{array}$ \\
\hline & Satisfaction with life as a whole (from 0 to 10 ) & Province of Córdoba & $\begin{array}{l}\text { OECD based on Gallup World Poll } \\
\qquad(2019)\end{array}$ \\
\hline
\end{tabular}




\begin{tabular}{c|l|c|c}
\hline 5 & $\begin{array}{l}\text { Percentage of the population that believe women are } \\
\text { treated with respect and dignity in their country }\end{array}$ & $\begin{array}{l}\text { Province of Córdoba } \\
\text { OECD based on Gallup World Poll } \\
(2019)\end{array}$ \\
\hline
\end{tabular}

Source: OECD (2020[3]), A Territorial Approach to the Sustainable Development Goals: Synthesis Report, https://doi.org/10.1787/e86fa715-en., OECD (2019[1]), How's Life in the Province of Córdoba, Argentina?, OECD Publishing, Paris, https://doi.org/10.1787/97f189b1-en.

Income inequality in Córdoba's agglomerations is low in comparison to OECD regions: $24 \%$ of the population in Córdoba's 4 main agglomerations is living with a gross income below the relative exclusion line $\left(60 \%\right.$ of the median regional income) (OECD, $\left.2019_{[1]}\right)$. They are thus exhibiting a lower degree of income inequality than $87 \%$ of OECD regions. On average, around one-third of the population in OECD regions are living below the relative exclusion line. Moreover, the Gini coefficient of gross income (where higher values represent greater inequality) of Córdoba's agglomerations was $0.37,10$ Gini points below the OECD average of 0.47 (where one Gini point represents one-hundredth in terms of the Gini index). Compared to Latin American regions, the positive performance of the Córdoba agglomerations is even more pronounced, as Córdoba's Gini coefficient is 13 Gini points lower than the average observed in Chile and Mexico (of around 0.5) (OECD, 2019[1]).

In Córdoba, the average number of rooms per inhabitant equals the Latin American average but lags behind the majority of OECD regions. Poor housing conditions, including overcrowding housing, can negatively affect aspects related to child development and adult health, among others (Tunstall et al., $\left.2013_{[7]}\right)$. In the OECD localised indicator framework for the SDGs, the number of rooms per person is considered a proxy for overcrowding conditions of households. In Córdoba's four main agglomerations (see Figure 2.2), people had around 1.3 rooms at their disposal in 2019. This is around 0.5 rooms less per inhabitant than the average of OECD regions (of close to 1.8 rooms per person). In around four out of five OECD regions, people had a larger number of rooms available than in Córdoba. Nevertheless, in the Latin American context, Córdoba aligns with the regional average (of 1.3 rooms per person in Brazil, Chile and Mexico).

Córdoba possesses vast areas of cropland - twice the share of the total area compared to OECD regions on average. SDG 2 has the objective to decrease the number of people worldwide suffering from hunger and achieve zero hunger by 2030. In that context, sustainable food production systems and the implementation of resilient agricultural practices are important contributory factors on the pathway to more sustainable agriculture that can contribute to higher food security. Corresponding to the fact that agriculture accounts for more than $20 \%$ of the provincial GDP, Córdoba is one of the regions with the largest share of cropland (measured as a percentage of total area) compared to OECD regions. In 2019 , around $68 \%$ of its area were cropland, which is more than twice the average of OECD regions of $32 \%$. It also exceeds by far the average share of cropland in other Latin American regions (19\%) and the national average of Argentina (23\%). In addition, the cropland area in Córdoba has remained relatively stable (around 1 percentage point increase between 1992 and 2019) and is thus close to the suggested end value of $0 \%$ (see (Haščič and Mackie, 2018[8]) for methodological details on land cover indicators).

Health-related indicators show a higher performance than that of most Latin American peers but lower than the OECD average. SDG 3 has the objective to ensure healthy lives and promote well-being for all ages. The average life expectancy at birth in the 4 main agglomerations of Córdoba was around 76 years in 2018 , around 4 years less than the average life expectancy in OECD regions. In terms of mortality rates, Córdoba is lagging slightly behind the OECD average. Infant mortality in the province was at 8 deaths of children 1-year-old or younger per 1000 live births between 2015 and 2017 compared to an average of OECD regions of 5.9. The gap towards the suggested end value of 2.8 deaths per 1000 live births based on the average of best-performing regions emphasises that Córdoba still has significant room for improvement. Nevertheless, the province is among the top-performing regions in comparison to its Latin American peers, where the average child mortality rate (15.6 deaths per 1000 live births) was close to 2 times the value of Córdoba. When looking at mortality rates for the 0-4 year-old population (per 
10000 people in the same age group), Córdoba's rate (10.5 deaths) is slightly lower than the average of OECD regions (11.8 deaths), with around $60 \%$ of OECD regions exhibiting lower child mortality rates than Córdoba. On the other hand, the province's child mortality rate was significantly below the Latin American average (23.8 deaths) and consequently ranked among the top $2 \%$ of Latin American regions in terms of this indicator (Figure 2.3).

Good health is also a prerequisite for life satisfaction overall. Here, Córdoba's results are similar to the average of OECD regions. With an average life satisfaction of 6.4 (on a scale from 0 to 10) between 2008 and 2018, which is also the average of regions in Argentina, Córdoba comes close to both the OECD regional average (and Latin American average) of around 6.5, as well as the suggested end value of 6.9 based on the best-performing OECD regions (see Box 2.2 for methodological limitations of Gallup data). Regarding community and social support, the four main agglomerations of Córdoba exhibit very good results compared to OECD regions. In 2018, around $97 \%$ of their population reported having someone they can rely on in the event of difficulties, which corresponds to the top $5 \%$ performers across OECD regions and first in the Latin American region (OECD, 2019 $\left.9_{[1]}\right)$.

Figure 2.3. Mortality rates (number of deaths) for the 0-4 year-old population per 10000 people, 2017

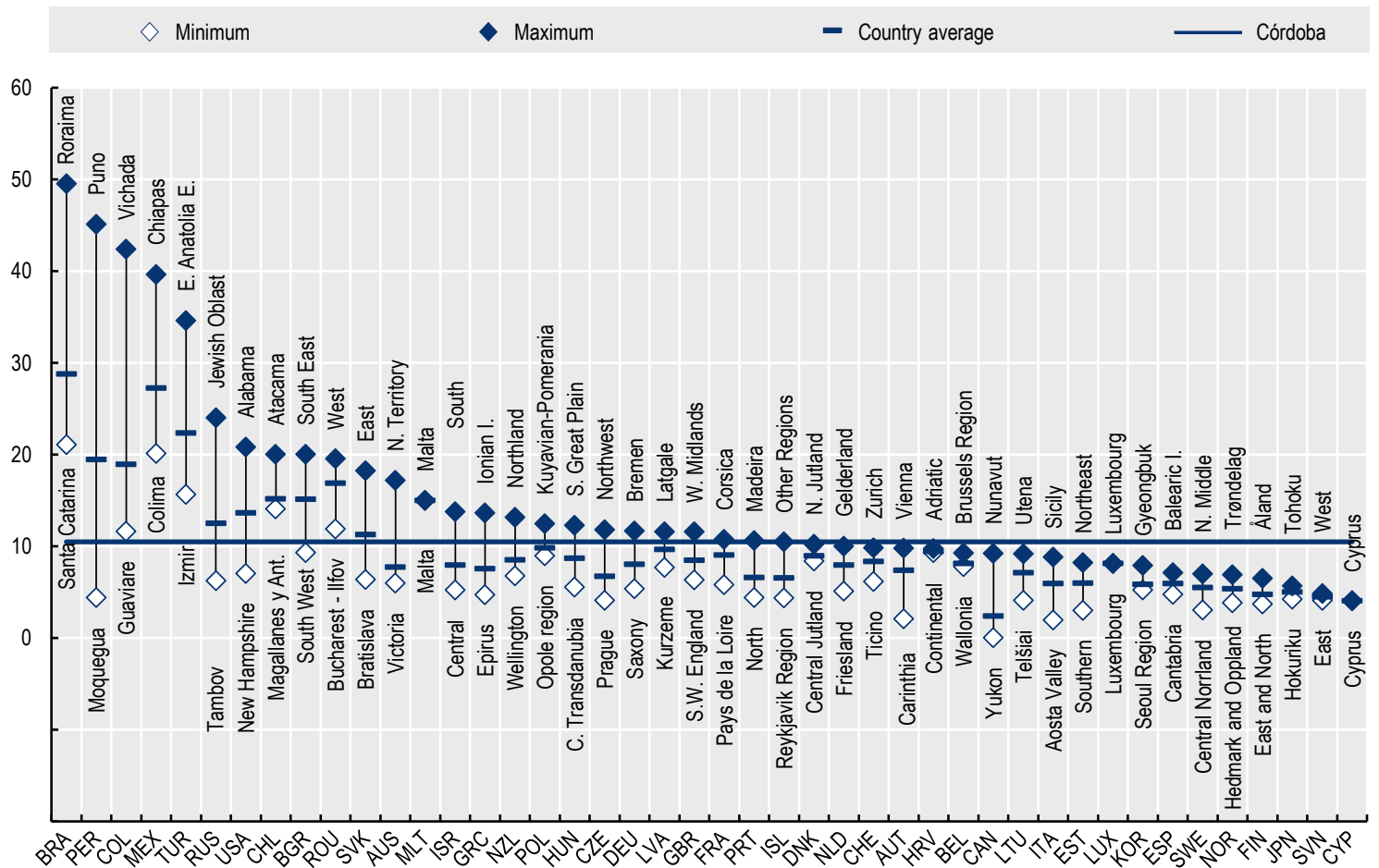

Note: Peru (2013); Australia (2015); Brazil, Chile, New Zealand, United States (2016); Córdoba (2017).

Source: OECD (2020[9]), OECD Regional Statistics (database), http://dx.doi.org/10.1787/region-data-en; Data for Córdoba comes from Estadísticas Vitales - Ministerio de Salud Córdoba (Vital Statistics - Ministry of Health of Córdoba).

In Córdoba, less than half of the population believes that women are treated with respect and dignity in their country. The achievement of gender equality and empowerment of all women and girls is at the core of SDG 5, which envisages a society with no discrimination against women and no differences in social or economic outcomes based on gender. Córdoba is still on the way to reach this goal. Self-reported survey data indicates that between 2008 and 2018, on average only 41\% of Córdoba's population believed that women are treated with respect and dignity in their country. In comparison, the average of OECD regions was significantly higher - although still far from the desired objective - and reached around $66 \%$. Despite 
the fact that this indicator does not measure the respect towards women in the region of Córdoba specifically, it points out a general issue in Argentina that also affects the province of Córdoba. Although more progress in gender equality is needed in Córdoba, the province is doing better than $75 \%$ of its Latin American peers, where the average of the aforementioned indicator is around 34\% (see Box 2.2 for methodological limitations of Gallup data). Córdoba also has a significant gender gap to close in terms of employment rates. The share of male employment is overall around 23.5 percentage points higher than female employment. The gender gap is thus larger than in OECD regions on average (15.6 percentage points) and there remains a considerable gap to the end value of 0 percentage points, which would represent full gender equality for this indicator. In a comparison among Latin American regions, Córdoba however performs better than the majority $(55 \%)$ of its peers.

\section{Planet: Satisfaction with water quality and degree of terrestrial protection are above the Argentinian average but tree cover and water body volumes are decreasing}

Three-quarters of Córdoba's population are satisfied with the quality of water in the province. SDG 6 targets one of the most fundamental requirements for human life, access to water and sanitation. One of its targets is to improve water quality by 2030. In Córdoba, the population's satisfaction with the quality of water reached an average satisfaction rate of $75 \%$ between 2008 and 2018 (see Box 2.2 for methodological limitations of Gallup data). The satisfaction rate was lower than in the majority of OECD regions. Overall, more than $70 \%$ of OECD regions exhibited a higher degree of satisfaction with their water quality during that period. On the other hand, it was higher than the average of Latin American peer regions (69\%) and Argentinian regions $(71 \%)$ over the same period. The suggested end value of $91 \%$ (based on the bestperforming OECD regions) also indicates that Córdoba still has some way to go to catch up with the top performers. However, water quality is only one aspect to be considered when it comes to SDG 6 . The quantity of water also has a role to play in the achievement of SDG 6 as the protection of water-related ecosystems is crucial for sustainable water supply management. In that context, Córdoba is one of the regions with the largest share of water bodies compared to OECD regions. In 2019 , close to $4 \%$ of its area were covered by water bodies while the national average was $1.5 \%$. Nevertheless, between 1992 and 2019, the province of Córdoba's water bodies have decreased by around 0.8 percentage points, which was among the highest decreases relative to OECD and other Latin American regions (see (Haščič and Mackie, 2018[8] for methodological details on land cover indicators).

\section{Table 2.3. OECD indicators used to assess the dimension Planet in Córdoba}

\begin{tabular}{|c|c|c|c|}
\hline SDG & Indicator & Geographic area covered & Data source \\
\hline \multirow[t]{3}{*}{7} & Percentage of the population satisfied with the quality of water & Province of Córdoba & $\begin{array}{l}\text { OECD based on Gallup } \\
\text { World Poll (2019) }\end{array}$ \\
\hline & Water bodies as a percentage of the total area in 2019 & Province of Córdoba & $\begin{array}{l}\text { OECD Environment } \\
\text { Database }\end{array}$ \\
\hline & Change in water bodies (from 1992 to 2019, percentage points) & Province of Córdoba & $\begin{array}{l}\text { OECD Environment } \\
\text { Database }\end{array}$ \\
\hline 8 & $\begin{array}{l}\text { Percentage of the population satisfied with the effort to preserve the } \\
\text { environment }\end{array}$ & Province of Córdoba & $\begin{array}{l}\text { OECD based on Gallup } \\
\text { World Poll (2019) }\end{array}$ \\
\hline 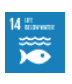 & Coastal area as a percentage of the total area & Province of Córdoba & $\begin{array}{l}\text { OECD based on Natural } \\
\text { Earth Database }\end{array}$ \\
\hline \multirow[t]{3}{*}{ re: } & Tree cover as a percentage of the total area in 2019 & Province of Córdoba & $\begin{array}{l}\text { OECD Environment } \\
\text { Database }\end{array}$ \\
\hline & Change in tree cover (from 1992 to 2019, percentage points) & Province of Córdoba & $\begin{array}{l}\text { OECD Environment } \\
\text { Database }\end{array}$ \\
\hline & Terrestrial protected areas as a percentage of the total area & Province of Córdoba & OECD based on WDPA \\
\hline
\end{tabular}

Source: OECD (2020[3]), A Territorial Approach to the Sustainable Development Goals: Synthesis Report, https://doi.org/10.1787/e86fa715-en. 
Around $30 \%$ only of Córdoba's population are satisfied with the government's efforts to preserve the environment. In addition to water, urgent action to combat climate change and its impacts, the key objective of SDG 13 Climate action is one of the core aspects of the dimension Planet. In Córdoba, the satisfaction with the government's efforts to preserve the environment, an indicator that reflects the general opinion about the intensity of the action taken for the environment and the climate, is rather low. According to selfreported survey data, the average satisfaction rate among Córdoba's population between 2008 and 2018 was around $31 \%$. Put into perspective, this value is more than 20 percentage points lower than the average of OECD regions (52\%), 14 percentage points lower than the average of Latin American peer regions (45\%) and around 9 percentage points lower than the average of Argentinian regions (40\%). Consequently, there also remains a considerable gap to close to the suggested end value based on the best-performing OECD regions (62\%) (see Box 2.2 for methodological limitations of Gallup data).

Tree cover has been slightly decreasing over the past decades and the degree of biodiversity protection is lower than the average of Latin American peer regions. One of the main targets of SDG 15 Life on land is to ensure the conservation, restoration and sustainable use of terrestrial and inland freshwater ecosystems and their services, in particular forests, wetlands, mountains and drylands. In Córdoba, the tree cover accounted for around $5 \%$ of the total area in 2019, a value which is low compared to the average of around 38\% in OECD regions and 39\% in Latin American regions. Moreover, between 1992 and 2019, the province has registered a decrease in tree cover of around 2.1 percentage points (Figure 2.4) (see (Haščič and Mackie, 2018[8]) for methodological details on land cover indicators). This development stands in contrast to SDG target 15.2 to promote the implementation of sustainable management of all types of forests, halt deforestation, restore degraded forests and substantially increase afforestation and reforestation globally. It also bears implications for SDG 13 as the restoration of trees is one of the most effective strategies for climate change mitigation (Bastin et al., 2019 ${ }_{[10]}$ ). Another means to ensure the conservation, restoration and sustainable use of terrestrial and inland freshwater ecosystems and their services is the establishment of protected areas such as nature reserves. In Córdoba, around $8.8 \%$ of its total area had a status of terrestrial protected area in 2017. This is on the one hand around 10 percentage points lower than the average of OECD regions (19.2\%) and also lower than in other Latin American regions on average $(15.6 \%)$ but, on the other, it exceeds the average share of terrestrial protection in Argentinian regions (8.6\%). 
Figure 2.4. Change in tree cover (percentage points), 1992-2015

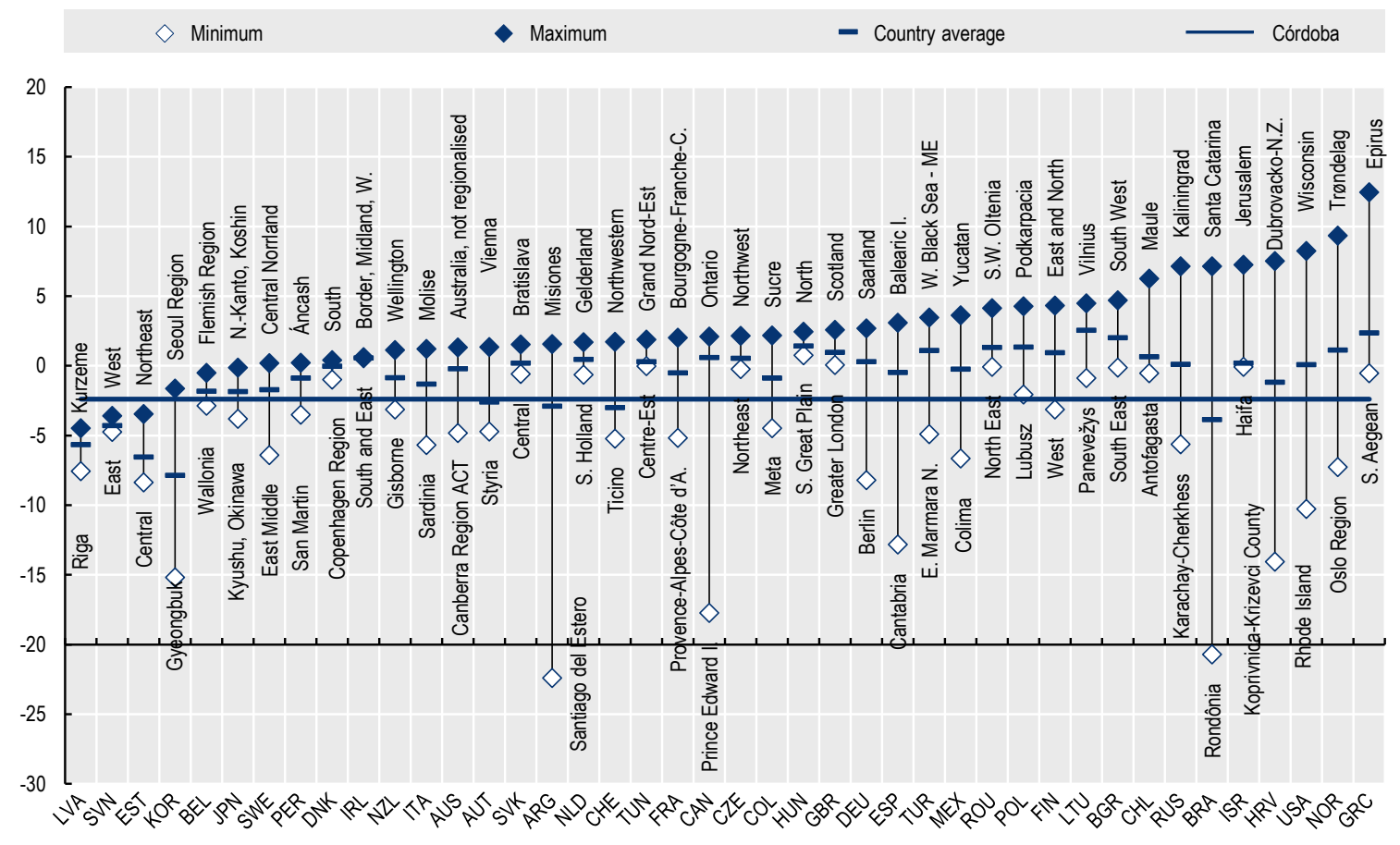

Source: OECD (2020[9]), OECD Regional Statistics (database), http://dx.doi.org/10.1787/region-data-en.

\section{Prosperity: Córdoba benefits from a highly educated population compared to most of its Latin American peers but labour market outcomes and infrastructure satisfaction indicators are lower than OECD averages}

Unemployment rates in Córdoba are similar to the average of OECD regions. SDG 8 Decent Work and Economic Growth is one of the key areas of the 2030 Agenda dimension Prosperity and aims, among other things, at promoting full and productive employment and decent work for all. Córdoba still has a certain distance to bridge in order to reach all these objectives. The unemployment rate in Córdoba's 4 main agglomerations of $7.6 \%$ (in the $2^{\text {nd }}$ semester of 2019 ) is equal to the average of OECD regions $(7.6 \%)$ but lies 2.6 percentage points above the suggested end value of $5 \%$ (based on the best performers). Overall, around two-thirds of OECD regions exhibit lower unemployment rates. Córdoba's unemployment rate also slightly exceeds the unemployment rates of Chilean and Mexican peer regions (of 6.3\%). At the same time, female unemployment is more prevalent in the four main agglomerations of Córdoba than male unemployment. The gender gap in the unemployment rate stood at 3.6 percentage points in 2018 compared to 2 percentage points in OECD regions on average. The corresponding average in peer Latin American regions was also lower (2.2 percentage points).

Almost half of Córdoba's unemployment rate comes from long-term unemployment. In its 4 main agglomerations, long-term unemployment (people unemployed for 12 months or more) accounted for $47.4 \%$ of all unemployment compared to $30 \%$ in OECD regions, on average (3.6\% out of the $7.6 \%$ of unemployed people). This stands in contrast to Latin American peer regions in Chile and Mexico, where incidences of long-term unemployment are very low. On average, these regions only record a share of long-term unemployment incidences of about $4 \%$. One of the core challenges of many OECD regions regarding SDG 8 is the integration of youth into the labour market, captured by the OECD framework through the indicator of youth unemployment of 18-24 year-olds. In the 4 main agglomerations of Córdoba, unemployed youth accounted for around $25 \%$ of the total population in that age range. Córdoba's youth 
unemployment rate is thus higher than in OECD regions on average $(16.7 \%)$ and also lies above the average of Latin American regions (13.5\%).

Secondary education degrees are more prevalent among Córdoba's population aged 25-64 than in the majority of Latin American regions and their share is close to the average of OECD regions. A well-qualified labour force is an important prerequisite for the achievement of the targets of SDG 8. In order to take this into account, the OECD's localised framework includes the indicator of the percentage of the labour force with at least upper secondary education. Due to data availability, the indicator for Córdoba considers the share of the population aged 25-64 with at least upper secondary education. In $2019,69 \%$ of people aged 25-64 years in Córdoba's 4 main agglomerations had at least upper secondary education. This is close to the OECD average of around $73 \%$ of the labour force having completed secondary education. Córdoba's share of the population with at least secondary education stands out in a comparison with Latin American regions, where the corresponding average share of the labour force with upper secondary education is $48 \%$, more than 20 percentage points lower than the share among Córdoba's population aged 25-64.

\section{Table 2.4. OECD indicators used to assess the dimension Prosperity in Córdoba}

\begin{tabular}{|c|c|c|c|}
\hline SDG & Indicator & $\begin{array}{l}\text { Geographic } \\
\text { area covered }\end{array}$ & Data source \\
\hline \multirow[t]{5}{*}{ 任 } & Unemployment rate $(\%)$ & $\begin{array}{c}4 \text { main } \\
\text { agglomerations }\end{array}$ & $\begin{array}{c}\text { Encuesta de Bienestar [Córdoba's Well-Being } \\
\text { Survey] }\end{array}$ \\
\hline & Gender gap in the unemployment rate (percentage points) & $\begin{array}{l}4 \text { main } \\
\text { agglomerations }\end{array}$ & $\begin{array}{l}\text { Encuesta de Bienestar [Córdoba's Well-Being } \\
\text { Survey] }\end{array}$ \\
\hline & Long-term unemployment incidence (\%) & $\begin{array}{l}4 \text { main } \\
\text { agglomerations }\end{array}$ & $\begin{array}{c}\text { Encuesta de Bienestar [Córdoba's Well-Being } \\
\text { Survey] }\end{array}$ \\
\hline & Youth unemployment rate (\%) & $\begin{array}{l}4 \text { main } \\
\text { agglomerations }\end{array}$ & $\begin{array}{c}\text { Encuesta de Bienestar [Córdoba's Well-Being } \\
\text { Survey] }\end{array}$ \\
\hline & Percentage of the labour force with at least secondary education & $\begin{array}{l}4 \text { main } \\
\text { agglomerations }\end{array}$ & $\begin{array}{c}\text { Encuesta de Bienestar [Córdoba's Well-Being } \\
\text { Survey] }\end{array}$ \\
\hline \multirow{5}{*}{ 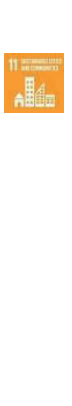 } & $\begin{array}{l}\text { Percentage of the population satisfied with the affordability of } \\
\text { housing }\end{array}$ & $\begin{array}{l}\text { Province of } \\
\text { Córdoba }\end{array}$ & OECD based on Gallup World Poll (2019) \\
\hline & $\begin{array}{l}\text { Difference between built-up area growth rate and population } \\
\text { growth rate (percentage points) }\end{array}$ & $\begin{array}{l}\text { Province of } \\
\text { Córdoba }\end{array}$ & OECD Regional Database \\
\hline & $\begin{array}{l}\text { Percentage of the population satisfied with the quality of public } \\
\text { transportation systems }\end{array}$ & $\begin{array}{l}\text { Province of } \\
\text { Córdoba }\end{array}$ & OECD based on Gallup World Poll (2019) \\
\hline & $\begin{array}{l}\text { Percentage of people exposed to more than } 10 \mu \mathrm{g} / \mathrm{m}^{3} \\
\text { (micrograms per cubic metre) of PM2.5 }\end{array}$ & $\begin{array}{l}\text { Province of } \\
\text { Córdoba }\end{array}$ & OECD Regional Database \\
\hline & $\begin{array}{l}\text { Exposure to PM } 2.5 \text { in } \mu \mathrm{g} / \mathrm{m}^{3} \text {, population-weighted (micrograms } \\
\text { per cubic metre) }\end{array}$ & $\begin{array}{l}\text { Province of } \\
\text { Córdoba }\end{array}$ & OECD Regional Database \\
\hline
\end{tabular}

Source: OECD (2020[3]), A Territorial Approach to the Sustainable Development Goals: Synthesis Report, https://doi.org/10.1787/e86fa715-en., OECD (2019 $\left.9_{[1]}\right)$, How's Life in the Province of Córdoba, Argentina?, OECD Publishing, Paris, https://doi.org/10.1787/97f189b1-en.

Improving satisfaction with the affordability of housing is a challenge for Córdoba. As the world is becoming increasingly urbanised and with more than half of the world's population living in cities, SDG 11 to make cities inclusive, safe, resilient and sustainable is of particular relevance in the 2030 Agenda (UN, 2020[11]). The objective of SDG target 11.1 is to ensure access for all to adequate, safe and affordable housing, an area where Córdoba has space for improvement. In Córdoba's 4 main agglomerations, housing expenditure (rental expenditure only) accounted for around 30\% of total household gross income in 2018, compared to an average of $20 \%$ in OECD regions (where, besides rent, housing expenditure includes services). Since the comparability of the housing expenditure indicator between Córdoba agglomerations and the OECD is limited, such comparative results should be seen only as a first approximation. Housing expenditure in the Córdoba agglomerations is higher than for $86 \%$ of OECD regions observed. Although 
the Córdoba agglomerations represent the urban part of the province and the share of housing expenditure could be expected to be higher than in regions that include large rural areas (as is the case for many OECD TL2 regions), there are a number of urban areas in OECD countries, such as Auckland, Greater London or Vienna, where housing expenditure is lower than one-quarter of the total household disposable income (OECD, 2019 $\left.{ }_{[1]}\right)$. In line with that, the average satisfaction of Córdoba's population with the affordability of housing between 2008 and 2018 was at a low 31\% compared to the average of OECD regions, which reached $53 \%$. Only $8 \%$ of OECD regions exhibited a lower rate of satisfaction with housing affordability. The satisfaction rate is also relatively low in comparison to other regions in Latin America. Only $10 \%$ of the regions in Argentina, Brazil, Colombia, Mexico and Peru exhibited lower satisfaction with housing affordability than Córdoba (see Box 2.2 for methodological limitations of Gallup data).

Satisfaction with the public transportation system is lower than in the majority of regions in both OECD and Latin American countries. At the same time, the population growth rate in Córdoba is higher than the builtup area growth rate, a phenomenon observed in the majority of Latin American regions. The difference between the 2 rates (built-up area-population) was -0.2 percentage points in both Córdoba and Latin American regions on average (period for rates: 2000-14). While the difference was rather small, a continued opposing development of the two growth rates over a longer period might put additional pressure on the housing market and infrastructure. The end value for the gap between land consumption rate and population growth rate was therefore established at zero, suggesting that to achieve sustainable urbanisation in the long term, the built-up area rate should follow the growth path of the population. In increasingly urbanising areas, public transport is an important factor for sustainable mobility and accessibility. In Córdoba, around $54 \%$ of the population were satisfied with the quality of the public transportation system between 2008 and 2018, slightly below the average of OECD regions, which was close to $60 \%$ over the same period. Around $70 \%$ of OECD regions and $64 \%$ of Latin American regions registered higher satisfaction rates. The differences between satisfaction rates in Córdoba on the one hand and the majority of OECD and Latin American regions on the other point out potential opportunities to improve the provision of public transport and infrastructure in the province (see Box 2.2 for methodological limitations of Gallup data).

Air pollution levels exceed the World Health Organization (WHO) air quality guidelines. Public transport can also play a role in the reduction of air pollution. In 2017, $100 \%$ of Córdoba's population were exposed to more than $10 \mu \mathrm{g} / \mathrm{m}^{3}$ (micrograms per cubic metre, annual mean) of particulate matter (PM) 2.5, which is the WHO guideline on air quality. Chronic exposure to such a level of PM2.5 particles can penetrate the lung barrier and enter the blood system, moreover contributing to the risk of developing cardiovascular and respiratory diseases, as well as lung cancer (WHO, 2018 $\left.{ }_{[12]}\right)$. In 2017, the average exposure to PM2.5 of people living in Córdoba was $15.1 \mu \mathrm{g} / \mathrm{m}^{3}$ (annual mean) and thus more than 5 micrograms per cubic metre above the WHO air quality guidelines. It was also higher than the average of OECD regions $\left(13.3 \mu \mathrm{g} / \mathrm{m}^{3}\right)$. On the other hand, it was however slightly lower than the average of peer regions in Latin America $\left(18 \mu \mathrm{g} / \mathrm{m}^{3}\right)$ but exceeded the national average of Argentina $\left(14.2 \mu \mathrm{g} / \mathrm{m}^{3}\right)$ (Figure 2.5). 
Figure 2.5. Exposure to PM2.5 in $\mu \mathrm{g} / \mathrm{m}^{3}$, population-weighted (micrograms per cubic metre), 2017

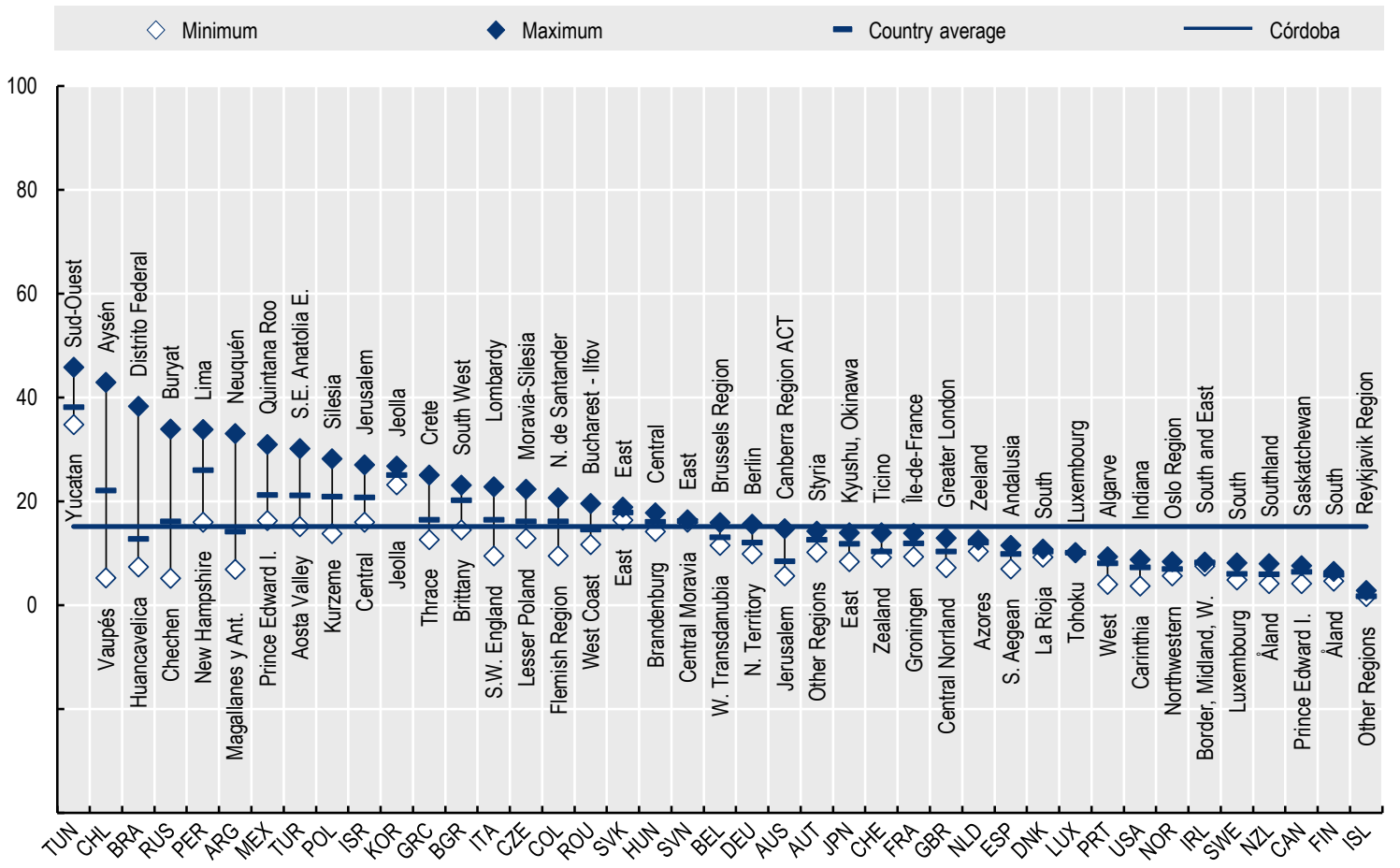

Source: OECD (2020[9]), OECD Regional Statistics (database), http://dx.doi.org/10.1787/region-data-en.

\section{Peace and Partnership: Low homicide rates compared to its Latin American peers but indicators on perceived safety and trust in the judicial system are below OECD averages}

Córdoba has one of the lowest homicide rates compared to its Latin American peers but safety is nevertheless an area where Córdoba is lagging behind the majority of OECD regions. SDG 16 has the objective to promote peaceful and inclusive societies for sustainable development, an area where the province of Córdoba has the potential to catch up with many OECD regions. Taking the number of victims of intentional homicide per 100000 people as a proxy of target 16.1 to significantly reduce all forms of violence and related death rates everywhere, Córdoba's four main agglomerations perform better than the average of OECD regions. Their homicide rate per 100000 people of 4.5 in 2019 was lower than the OECD average of 5.3 (Figure 2.6). It has to be noted, however, that the OECD average value is the result of high homicide rates in Latin American regions of OECD countries, which registered close to 18 cases of murder per 100000 people and year on average. As a consequence, the homicide rate in Córdoba is still higher than in about $75 \%$ of OECD regions, while Córdoba's homicide rate was among the lowest $10 \%$ compared to peer regions in Latin America. This is in line with self-reported survey data on the perception of safety in the province. Between 2008 and 2018, less than half of Córdoba's population (45\%) stated to feel safe walking alone at night around the area they live in. Córdoba's feeling of safety is thus lower than in OECD regions on average $(66 \%)$ and the suggested end value of $79 \%$ based on the best-performing regions. Overall, it is similar to the average of Latin American peers (47\%) and slightly exceeds the average of Argentinian regions of $42 \%$ (see Box 2.2 for methodological limitations of Gallup data). 
Table 2.5. OECD indicators used to assess the dimensions Peace and Partnership in Córdoba

\begin{tabular}{|c|c|c|c|}
\hline SDG & Indicator & Geographic area covered & Data source \\
\hline \multirow{7}{*}{$\underline{y}$} & Homicides per 100000 persons & 4 main agglomerations & $\begin{array}{l}\text { Observatory of studies on coexistence and citizen } \\
\text { security of the province of Córdoba }\end{array}$ \\
\hline & $\begin{array}{l}\text { Percentage of the population that feel } \\
\text { safe walking alone at night around } \\
\text { the area in which they live }\end{array}$ & Province of Córdoba & OECD based on Gallup World Poll (2019) \\
\hline & $\begin{array}{l}\text { Confidence in the judicial system and } \\
\text { courts }\end{array}$ & Province of Córdoba & OECD based on Gallup World Poll (2019) \\
\hline & $\begin{array}{l}\text { Percentage of the population that } \\
\text { believes corruption is spread } \\
\text { throughout the government in the } \\
\text { country }\end{array}$ & Province of Córdoba & OECD based on Gallup World Poll (2019) \\
\hline & $\begin{array}{l}\text { Percentage of the population that } \\
\text { have confidence in the national } \\
\text { government }\end{array}$ & Province of Córdoba & OECD based on Gallup World Poll (2019) \\
\hline & Voter turnout & 4 main agglomerations & National election office \\
\hline & $\begin{array}{l}\text { Percentage of the population that } \\
\text { believes their place of residence is a } \\
\text { good place to live for gay or lesbian } \\
\text { people }\end{array}$ & Province of Córdoba & OECD based on Gallup World Poll (2019) \\
\hline (17) & $\begin{array}{l}\text { Percentage of households with } \\
\text { (broadband) Internet access }\end{array}$ & 4 main agglomerations & $\begin{array}{c}\text { Encuesta de Bienestar [Córdoba's Well-Being } \\
\text { Survey] }\end{array}$ \\
\hline
\end{tabular}

Source: OECD (2020[3]), A Territorial Approach to the Sustainable Development Goals: Synthesis Report, https://doi.org/10.1787/e86fa715-en., OECD (2019[1]), How's Life in the Province of Córdoba, Argentina?, OECD Publishing, Paris, https://doi.org/10.1787/97f189b1-en.

Less than half of Córdoba's population has confidence in the judicial system and in the national government. SDG 16 not only targets safety but also aims to achieve the provision of access to justice for all and build effective, accountable and inclusive institutions at all levels. In that area, Córdoba has significant room for improvement in order to achieve the objectives of the 2030 Agenda. Between 2008 and 2018 , less than $30 \%$ of its population had confidence in the judicial system and courts. In comparison, the average of OECD regions was close to $50 \%$ with the best-performing regions achieving rates of nearly $60 \%$. The confidence in the judicial system and courts was overall slightly lower than in the majority of its Latin American peer regions, where on average one-third of the people stated to have confidence in the judicial system and also below the Argentinian average of $31 \%$. In addition, only one out of four residents in Córdoba had confidence in the national government, while the average of OECD regions was above $40 \%$ and Argentina's country average reached 38\% in the period between 2008 and 2018 . The perception of corruption points in a similar direction of mistrust. Between 2008 and 2018, close to $90 \%$ of people in Córdoba stated to believe that corruption is spread throughout the government in the country, while the average of OECD regions (62\%) was considerably lower. A comparison with the average of other regions in Argentina and other Latin American regions shows similar results. Compared to the province of Córdoba, a lower percentage of people believes that corruption within the government is widespread in both Latin American regions (75\%) and other Argentinean provinces (78\%) (see Box 2.2 for methodological limitations of Gallup data). Regarding political participation outcomes, the 4 main agglomeration's voter turnout was around $80 \%$ in the last national election, a very high level compared to most OECD regions, although this is partially the result of a compulsory voting policy in Argentina 
Figure 2.6. Homicides per 100000 persons, 2016

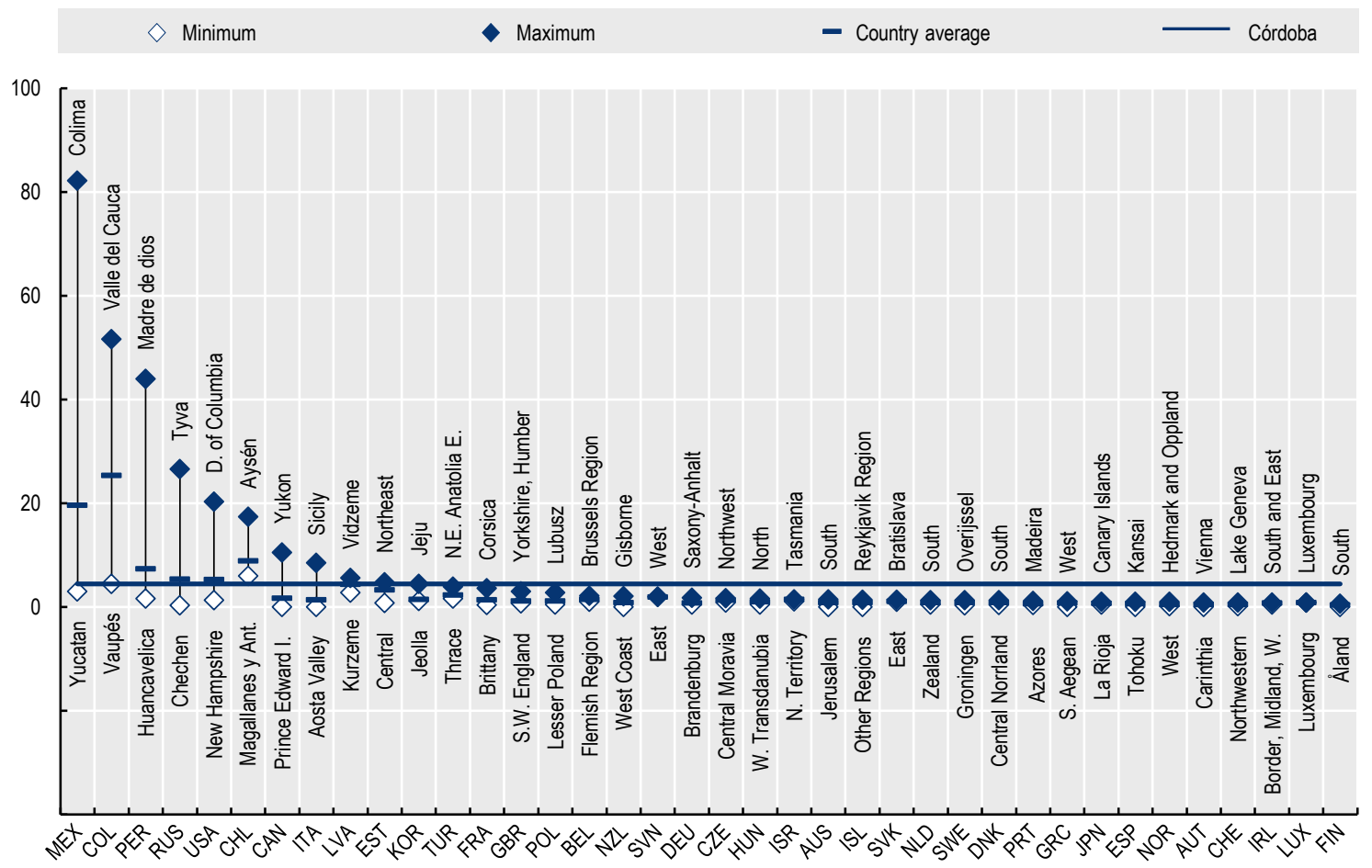

Note: Netherlands (2009); Slovenia (2012); Italy, Turkey (2013); New Zealand, Peru, Sweden (2014); Iceland, Israel, Japan, Korea, Latvia (2015); Germany, Russia (2018), Córdoba (2019).

Source: OECD (2020[9]), OECD Regional Statistics (database), http://dx.doi.org/10.1787/region-data-en; Data for Córdoba comes from Observatorio De Estudios Sobre Convivencia Y Seguridad Ciudadana (Observatory for Studies on Coexistence and Public Security, Government of the Province of Córdoba).

The majority of people in Córdoba believes their place of residence is a good place to live for migrants and gay or lesbian people. Another key objective of SDG 16 is Target 16.b to promote and enforce nondiscriminatory laws and policies for sustainable development, a target which the OECD measures through proxy indicators about the perceived liveability of the region for different minority groups. Here, Córdoba shows more positive results than in the other indicators of SDG 16. Regarding gay or lesbian people, the share of the population believing that their place of residence is a good place for them to live reached $58 \%$ between 2008 and 2018, thus exceeding the average of OECD regions (53\%) and regions in Latin America $(52 \%)$ but slightly lagging behind the average of Argentinian peers $(61 \%)$. However, there remains a considerable gap to the end value for 2030 , which is defined at $100 \%$, corresponding to an absence of any type of discrimination (see Box 2.2 for methodological limitations of Gallup data).

The connectivity to Internet in Córdoba is slightly lower than in OECD regions on average. SDG 17 has the objective to strengthen the means of implementation and revitalise the global partnership for sustainable development. One important factor that facilitates the global partnership for sustainable development is ICT as expressed under SDG Target 17.8. In that context, the OECD uses the percentage of households connected to the Internet as a proxy to capture the use of "enabling-technologies". Around $70 \%$ of households in Córdoba's 4 largest agglomerations had access to broadband Internet in 2019, which was close to the average of OECD regions of $74 \%$ (Figure 2.7). Compared with other regions in Latin America, the share of Internet users is high. Access to Internet in the agglomerations of Córdoba is higher than the country averages in Brazil, Chile and Mexico. 
Figure 2.7. Percentage of households with broadband Internet access, 2016

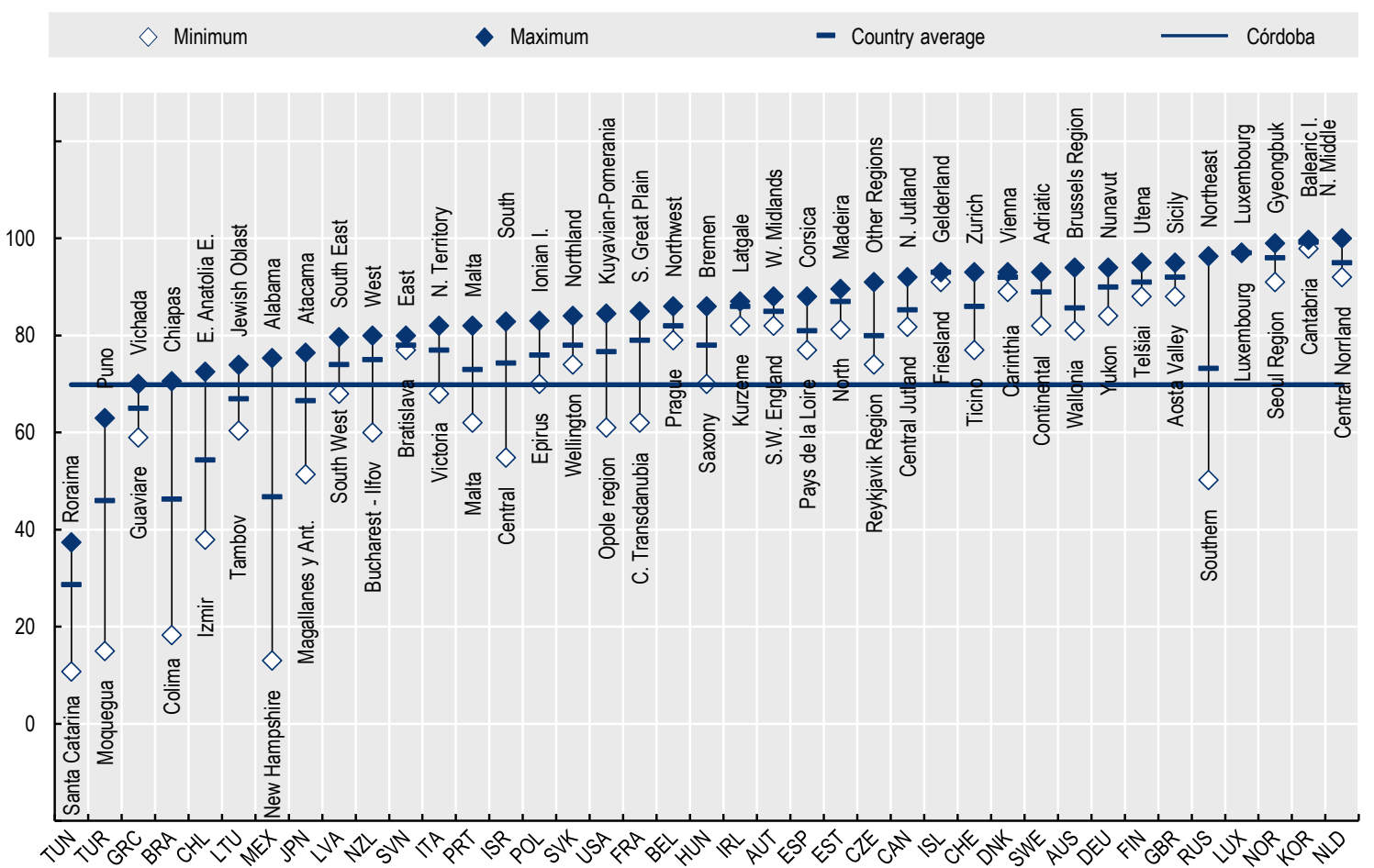

Note: Iceland, New Zealand (2012); Bulgaria, Chile, Turkey (2013); Greece, Switzerland, Tunisia (2014); Australia, Canada, Estonia, Japan, Israel, Latvia, Lithuania, United States (2015); Russia (2018). While for the majority of OECD regions this indicator refers to broadband Internet access, this restriction does not apply to the Córdoba agglomerations.

Source: OECD (2020[9]), OECD Regional Statistics (database), http://dx.doi.org/10.1787/region-data-en; Data for Córdoba comes from Observatorio De Estudios Sobre Convivencia Y Seguridad Ciudadana (Observatory for Studies on Coexistence and Public Security, Government of the Province of Córdoba). 


\section{References}

Bastin, J. et al. (2019), "The global tree restoration potential", Science, Vol. 365/6448, pp. 76-79, http://dx.doi.org/10.1126/science.aax0848.

Brezzi, M. and M. Diaz Ramirez (2016), "Building subjective well-being indicators at the subnational level: A preliminary assessment in OECD regions", OECD Regional Development Working Papers, No. 2016/3, OECD Publishing, Paris, https://dx.doi.org/10.1787/5jm2hhcjftvh-en.

Gallup World Poll (2020), Worldwide Research Methodology and Codebook.

Haščič, I. and A. Mackie (2018), "Land Cover Change and Conversions: Methodology and Results for OECD and G20 Countries", OECD Green Growth Papers, No. 2018/04, OECD Publishing, Paris, https://dx.doi.org/10.1787/72a9e331-en.

OECD (2020), A Territorial Approach to the Sustainable Development Goals: Synthesis report, OECD Urban Policy Reviews, OECD Publishing, Paris, https://dx.doi.org/10.1787/e86fa715en.

OECD (2020), Measuring the Distance to the SDGs in Regions and Cities (visualisation tool), OECD, Paris, http://www.oecd-local-sdgs.org.

OECD (2020), OECD Regional Statistics (database), OECD, Paris, http://dx.doi.org/10.1787/region-data-en.

OECD (2019), How's Life in the Province of Córdoba, Argentina?, OECD Publishing, Paris, https://dx.doi.org/10.1787/97f189b1-en.

Tunstall, R. et al. (2013), The Links between Housing and Poverty: An Evidence Review, Joseph Rowntree Foundation, https://www.jrf.org.uk/sites/default/files/jrf/migrated/files/povertyhousing-options-full.pdf (accessed on 10 August 2020).

UN (2020), Goal 11: Make Cities Inclusive, Safe, Resilient and Sustainable, United Nations, https://www.un.org/sustainabledevelopment/cities/ (accessed on 11 August 2020).

UN (2020), Sustainable Development Goals, United Nations Sustainable Development Knowledge Platform, https://sustainabledevelopment.un.org/?menu=1300.

WHO (2018), Ambient (outdoor) Air Pollution - Key Facts, World Health Organization, https://www.who.int/en/news-room/fact-sheets/detail/ambient-(outdoor)-air-quality-and-health.

\section{Notes}

${ }^{1}$ While a total of 135 indicators are available for the measurement of the SDGs in both regions and cities in OECD countries, the coverage varies depending on the type of geographical unit to which each indicator is associated. While 122 indicators (covering $59 \%$ of subnational SDG targets) are available for regions, only 56 indicators (covering $32 \%$ of subnational SDG targets) are currently available for cities. Although the set of indicators aims to cover the broad spectrum of all 17 SDGs, the coverage in terms of indicators also varies widely across SDGs. 
2 Due to data availability, some of the indicators considered in the report only capture the four main agglomerations of the province of Córdoba instead of the whole province. These indicators are the following: Rooms per person, Mortality rates for the 0-4 year-old population per 10000 people, Infant mortality rate (number of deaths of children 1-year-old or younger per 1000 live births), Unemployment rate (\%), Long-term unemployment incidence (\%), Employment rate (\%), Homicides per 100000 persons, Voter turnout in the last national election, and Percentage of households with broadband Internet access.

${ }^{3}$ Due to data availability, not all indicators cover data for all Latin American countries mentioned in the text. The following indicators consider data from:

- Argentina, Brazil, Chile, Mexico, Peru: Percentage of people exposed to more than $10 \mu \mathrm{g} / \mathrm{m}^{3}$ (micrograms per cubic metre) of PM2.5.

- Argentina, Brazil, Chile, Colombia, Costa Rica, Mexico, Peru: Percentage of the population satisfied with efforts to deal with poverty, Cropland as a percentage of the total area in 2015, Satisfaction with life as a whole (from 0 to 10), Percentage of the population that believe women are treated with respect and dignity in their country, Percentage of the population satisfied with the quality of water, Change in water bodies (from 1992 to 2015, percentage points), Water bodies as percentage of the total area in 2015. Percentage of the population satisfied with affordability of housing, Percentage of the population satisfied with the quality of public transportation systems, Difference between built-up area growth rate and population growth rate (percentage points), Percentage of the population satisfied with the effort to preserve the environment, Coastal area as a percentage of the total area, Change in tree cover (from 1992 to 2015, percentage points), Tree cover as a percentage of the total area in 2015 , Terrestrial protected areas as a percentage of the total area, Percentage of the population that feel safe walking alone at night around the area in which they live, Confidence in the judicial system and courts, Percentage of the population that believes corruption is spread throughout the government in the country, Percentage of the population that have confidence in the national government, Percentage of the population that believes their place of residence is a good place to live for gay or lesbian people.

- Argentina, Brazil, Chile, Colombia, Mexico, Peru: Change in cropland (from 1992 to 2015, percentage points), Exposure to PM2.5 in $\mu \mathrm{g} / \mathrm{m}^{3}$, population weighted (micrograms per cubic metre).

- Brazil, Chile, Colombia, Costa Rica, Mexico: Percentage of the labour force with at least secondary education.

- Brazil, Chile, Colombia, Mexico: Youth unemployment rate (\%).

- Brazil, Chile, Colombia, Mexico, Peru: Mortality rates for the 0-4 year-old population.

- Brazil, Chile, Mexico: Rooms per person, Percentage of households with broadband Internet access.

- Chile, Colombia, Mexico: Gender gap in employment rate (male-female, percentage points), Unemployment rate (\%), Gender gap in unemployment rate (percentage points).

- Chile, Colombia, Mexico, Peru: Infant mortality rate (number of deaths of children 1-year-old or younger per 1000 live births), Homicides per 100000 persons.

- Chile, Mexico: Long-term unemployment incidence (\%), Gross household income (before taxes and transfers) adjusted per unit of consumption ("equivalised"), Gini index of gross income ( 0 for perfect equality, 1 for perfect inequality), Percentage of people (aged 18 or more) who have at least one friend they can rely on if needed. 


\section{The multi-stakeholder and} participatory process to localise the SDGs in the province of Córdoba

In order to use the SDGs as a policymaking tool, Córdoba has initiated a multi-stakeholder engagement process to identify and measure synergies and trade-offs between its prioritised SDG targets. This process has led to the development of a matrix and concrete strategic lines of action for the achievement of the SDGs to address many trends affecting the province of Córdoba such as demographic changes causing pressures on the housing market, the lack of employment opportunities for youth, women and people with disabilities, water management and climate change. The government of Córdoba has also developed an Open Management Portal in order to raise awareness on the SDGs, while also striving to further engage the private sector on the SDGs. 


\section{Vertical and horizontal co-ordination to implement the SDGs in Córdoba}

Argentina's federal structure grants the province of Córdoba and its municipalities key responsibilities for many of the policies that have a very direct impact on people's lives (Box 3.1). Many decisions in various sectors are taken at the provincial and municipal levels. The province of Córdoba, for example, has exclusive responsibility for pre-school, primary and secondary education, education for special groups and adults, as well as professional and technical training. Other areas of provincial responsibility include social housing, environment and citizen safety. The provincial-level responsibilities may include both policymaking and policy execution, which translates into large expenditure and investment by the subnational levels of government. As such, the bulk of provincial government spending in Córdoba, around $48 \%$ of expenditure of the 2018 budget, is dedicated to providing social services, including health, education, jobs and housing, among others.

\section{Box 3.1. Federal structure of Argentina}

Argentina is a federal state with 3 levels of government: i) the national level, with a democratically elected executive and a bicameral legislature; ii) the provincial level, with 23 provinces plus the autonomous city of Buenos Aires; and iii) the municipal level. All responsibilities and powers not delegated by the Constitution to the national government are in the hands of the provinces. Moreover, each province has its own Constitution and government institutions. The provincial Constitutions define the institutional, political, administrative, economic and financial scope of each provincial government.

The provinces may create regions (sometimes called departments) within their administrative boundaries for the purpose of economic and social development. They may also enter into international agreements, provided such agreements: i) are reported to the national Congress; ii) are not incompatible with national foreign policy; and iii) do not infringe upon the delegated powers of the national government. The national Constitution requires that provincial governments guarantee municipal autonomy and establish municipal systems and rules as part of their own provincial Constitutions.

Source: OECD (2016[11]), OECD Territorial Reviews: Córdoba, Argentina, https://doi.org/10.1787/978926 4262201-en.

To promote vertical co-ordination for the 2030 Agenda implementation, the province of Córdoba has signed a co-operation agreement with the National Council for the Coordination of Social Policies (Consejo Nacional de Coordinación de Políticas Sociales, CNCPS) in November 2017. The co-operation agreement recognises that the CNCPS is the institution responsible for co-ordinating the actions needed for the effective implementation of the 2030 Agenda and that Argentina, as a federal country, needs the participation of the provinces to achieve the targets. The agreement also stresses that each province should select its own SDG targets and indicators and undertake the necessary efforts to achieve sustainable development objectives pursued at the national level. By doing so, the agreement aims to promote coherence between the targets of the various provinces. Through the signature of the agreement, Córdoba committed to:

- Define the focal points within the government responsible for the development, adaptation and monitoring of the SDGs and provide the resources needed for this purpose.

- Define the indicators for monitoring the SDGs at provincial level.

- Define the final and intermediary SDGs and targets applicable to the specific social and political conditions of Córdoba. 
- Design and/or reformulate policies and programmes in order to adapt them to the SDGs.

- Support the CNCPS in the development of SDG initiatives in the government and among provincial stakeholders.

- Prepare a final report for the CNCPS with the results of the process of localising the SDGs.

Together with the agreement, the CNCPS provides the provinces with an adaptation guide whose main objective is to provide guidelines and methodological suggestions on the utilisation of the SDGs as a management and planning tool at the subnational level. The collaboration agreement with the CNCPS provides a soft mechanism to promote vertical co-ordination on actions related to the SDGs. All the provinces that signed the co-operation agreement with the CNCPS regularly hold federal meetings to set a common agenda and share good practices. The CNCPS, UN agencies, the Ministry of Foreign Affairs and Worship, the National Institute of Statistics and Censuses (Instituto Nacional de Estadística y Censos, INDEC), provincial representatives of the National Tax and Social Identification System (Sistema de Identificación Nacional Tributario y Social, SINTyS) and different provincial statistical offices also participate in these meetings. The CNCPS also invites the provinces to contribute to the SDG Provinces Reports (Informe ODS Provincias), which illustrate and highlight the progress on the adaptation of the SDGs in each territory. Córdoba's latest contribution was released in 2019 covering the progress on Córdoba's provincial prioritisation process for the SDGs, programmes linked to the SDGs and actions undertaken for the dissemination of the SDGs in the province during the years 2018 and 2019. Other provinces that have published an SDG Province Report are Buenos Aires, Chaco, La Pampa, La Rioja, Mendoza, Rio Negro, Santa Fe and Santiago del Estero.

Since 2019, the Ministry of Coordination of the province of Córdoba has been responsible for the co-ordination of the provincial policies related to the 2030 Agenda. It supersedes the General Secretariat of the government, which is part of the Ministry of Coordination, as the body responsible for co-ordinating the actions for the effective implementation of the 2030 Agenda, enabling inter-ministerial work and bilateral relations with the bodies co-ordinating the implementation of the SDGs. The Ministry of Coordination, as the SDG focal point for the province of Córdoba, also co-ordinates the operation of the Inter-Ministerial SDG Board, in which all executive departments of the province participate. Each ministry, agency and secretariat defined as a representative who is part of the Inter-Ministerial SDG Board. The main task of the board is to act as a forum, where SDG-related programmes and initiatives of each division and their linkages are proposed and analysed by the different representatives. At the same time, the board is also working on the establishment of relevant indicators to measure the impact of government actions. Overall, the Inter-Ministerial SDG Board consists of 37 representatives from all executive branch departments, including the General Directorate of Statistics and Censuses (DGEyC). In 2018, it held more than 40 meetings.

\section{Box 3.2. Horizontal and vertical policy co-ordination in the province of Córdoba}

Territorial development practices in Córdoba are confronted with a large number of autonomous municipalities (427), by the provincial constitution, which can be a challenge when it comes to co-operation in policy implementation or service programming among them (horizontal co-ordination) and with the provincial administration (vertical co-ordination). Beyond that, the economic and demographic weight represented by the city of Córdoba and its surrounding municipalities (Greater Córdoba) also has an impact on the province's territorial development practices. As a result of this autonomy granted by the constitution, the provincial government and relevant local government officials seem to recognise that there is the need for a more strongly co-ordinated and more "metropolitan" approach to governance in the Greater Córdoba area. 
In Córdoba, the impact of scale on public service delivery (mainly electricity, gas, and water) at the local or community-based level has been managed mostly through the existing service co-operatives (cooperativas). Service co-operatives reach about $30 \%$ of the population and cover approximately $70 \%$ of the territory. The existence of service co-operatives reduces the need for inter-municipal co-operation for service delivery and it is one possible explanation of why horizontal co-ordination mechanisms have not evolved strongly in Córdoba. However, other services, such as public transportation or bridging gaps to meet administrative, operational and infrastructure needs could still benefit from inter-municipal co-operation. A successful example is the experience of six municipalities collaborating with the objective of building a common solid waste treatment plant. The municipalities agreed to co-operate, signed an agreement (convenio), selected the site within the administrative territory of one of the participants, La Carlota, and constructed the plant.

Vertical co-ordination between the province and the municipalities is also a challenge, despite the existence of the Province and Municipalities Roundtable (Mesa de la Provincia y los Municipios), which was conceived as a co-ordinating body in response to the absence of incentive structures for local authorities to engage in provincial policy or service programming. One example is urban sprawl in Greater Córdoba that arises for several reasons including fragmented land use planning policy and regulations (land use planning is entirely a municipal competency). This can lead to approval for construction of housing developments where there is no appropriate infrastructure in place (e.g. water, sewage, electricity, etc.), just as it can result in constructions in high-risk areas. However, there is no consensus as to the effectiveness of the Province and Municipalities Roundtable so far.

Source: OECD (2016[1]), OECD Territorial Reviews: Córdoba, Argentina, https://doi.org/10.1787/9789264262201-en.

In October 2020, the province of Córdoba was selected by the Open Government Partnership (OGP), a multilateral initiative promoting open government principles, to participate in the global pilot project OGP Local. The project brings together 56 subnational governments (provincial, municipal and communal) from all over the world and has the objective of implementing an OGP Action Plan through the co-creation of public policies with various interest groups and levels of government. The participation in the project deepens Córdoba's work in the field of open government to achieve the SDGs. As part of the project, the province is expected to start a process of collaborative territorialisation of the SDGs in its 427 municipalities and communes. Based on the experience of the territorialisation process developed at the provincial level (see below), the new project also engages with local organisations. The two non-governmental organisations (NGOs) FUNDEPS (La Fundación para el Desarrollo de Políticas Sustentables) and PARES are expected to accompany the territorialisation process in the municipalities, and will also involve civil society organisations, enterprises and academic institutions from each municipality.

\section{The SDGs as a tool to engage citizens, youth, private sector and civil society}

The province of Córdoba recognises the importance of stakeholder engagement and has started to develop its SDG awareness-raising and stakeholder engagement strategy, both internally and externally. Internally, the government is sensitising its staff through members of the Inter-Ministerial SDG Board that act as focal points in each government department. Externally, the province is using a number of communication, information and training tools that are discussed more in-depth below.

\section{Using communication and data tools to raise awareness of the SDGs}

In order to foster raise awareness of the SDGs, the government of Córdoba has developed an Open Management Portal. In 2017, the province of Córdoba launched an Open Government Roundtable (Mesa 
de Gobierno Abierto) composed of civil society organisations and representatives from academia to work on the institutionalisation of open government principles in the province. The establishment of this roundtable relates to the province's goal to lead open government initiatives by example, which was also the motivation for the development of an Open Management Portal. This portal is a visual web platform through which the general public can access information related to the three axes of governmental actions aligned with the SDGs. For example, each visitor of the portal can choose to select an SDG to learn more about government initiatives and projects targeted towards the achievement of that specific SDG. The portal also incorporates a news section illustrating the latest government actions related to the SDGs. Moreover, it provides visual information and data related to the different government actions and the progress on the SDGs, budgeting, public accounts, laws and regulations and the responsible ministries and agencies among other things. For the government of Córdoba, the portal thus represents a key communication tool to promote its activities on the 2030 Agenda. It was created as part of the Third Action Plan for Open Government Argentina (Tercer Plan de Acción de Gobierno Abierto), which was launched by the national government as a means to advance transparency and accountability, two fundamental axes of the principle of open government (Ministry of Modernisation of the Republic of Argentina, 2017 ${ }_{[2]}$ ).

Within the framework of the provincial goals of the Third Action Plan for Open Government, Córdoba has launched a series of virtual training sessions for managers and heads of government with the aim of promoting open government knowledge and tools in the provincial public administration. The courses seek to introduce best practices that support the design, implementation and development of open government policies. Likewise, they incorporate examples from different countries around the world, with special emphasis on experiences from Latin America. The training contents were co-created with the organisations that are part of the Open Government Roundtable. They were also incorporated as part of the Provincial government's Annual Training Plan using the SDGs as a key training axis (Government Secretariat for the Modernisation of the Nation, Argentina, 2019 $\left.9_{[3]}\right)$. Through its Provincial Institute of Municipal Training IPCaM (Instituto Provincial de Capacitación Municipal), the province of Córdoba also offers specific public management trainings for government officials on the principles of the 2030 Agenda and the SDGs focusing on concepts and practical tools for their implementation at the local level. These trainings have been developed in active collaboration with international such as the UN and national organisations such as CNCPS. In addition, the courses incorporate international experience and best practices from other local and regional governments, including the region of Flanders, Belgium, the states of Pará and Paraná, Brazil, and several Argentinian provinces and municipalities.

The province of Córdoba also organised training sessions to provide young people with knowledge on the 2030 Agenda and principles of open government. The government of Córdoba considers young people as fundamental actors in achieving structural transformations on the road to sustainable development. To raise awareness among its young population, the province has therefore organised a Youth and Open Government seminar in June 2019 that involved the active participation of 230 young people between 17 and 25 years of age. High school and university students as well as young professionals participated in five workshops organised and conducted in collaboration with the civil society organisations involved in the Open Government Roundtable. The workshops were held simultaneously and became fora for the exchange and discussion about the main concepts of the open government paradigm and its link to the SDGs. The participants elaborated on a number of topics including: "Innovation through digital technologies" (SDGs 9 and SDG 10); "Citizenship and participation in the framework of open government" (SDGs 5, 10, 16 and 13); "Young people asking for information" (SDGs 3 and 4); "Thinking about collaboration with youth" (SDG 11); and "Why do we need an open government? The SDGs as our common horizon" (Government Secretariat for the Modernisation of the Nation, Argentina, 2019 $\left.{ }_{[3]}\right]$.

\section{The incipient engagement of the private sector in implementing the 2030 Agenda can be strengthened}

The province does not yet have a defined strategy on the engagement of the private sector, which is one of the key challenges and priorities of the government in the short term. Nonetheless, a number of private 
sector companies in Córdoba are active on the 2030 Agenda, although not always aware of the link between their activities and the SDGs. Several companies are, directly or indirectly, addressing the SDGs beyond their corporate social responsibility (CSR) activities (Table 3.1).

However, most of the companies are only focusing on a few specific SDGs, such as water, food security or decent work and economic growth. Some companies perceive the SDGs as a legacy or continuation of their sustainability reporting and CSR activities, whereas others are taking a holistic approach to the SDGs. Some companies already have good experience in monitoring and sustainability reporting, on which they are now building their SDGs activities. The main challenge for a majority of companies is the integration of the SDGs into their core business in a cross-cutting way, beyond CSR. In most cases, this is not yet happening and the transformative element of the 2030 Agenda is therefore not fully exploited. Some companies are however moving in this direction and are considering how to embed the SDGs in their dayto-day functioning and use them as a business opportunity.

\section{Table 3.1. Non-exhaustive list of companies active on the SDGs in Córdoba}

\begin{tabular}{|c|c|}
\hline Company & Activities \\
\hline Libertad & $\begin{array}{l}\text { Libertad is a retail company that addresses the SDGs through its CSR strategy. The main focus is on food security } \\
\text { and circular economy. Before the adoption of the } 2030 \text { Agenda, the company was mainly focusing on the UN } \\
\text { Global Compact principles but Libertad is now increasingly addressing the SDGs. }\end{array}$ \\
\hline Trasus & $\begin{array}{l}\text { Trasus, a transparency and sustainable development consulting firm, works with the Ministry of Finance's } \\
\text { sustainability reports. The company develops its own sustainability report and supports other companies in the } \\
\text { preparation of their sustainability reports. Trasus identified SDGs } 1,2,3,4 \text { and } 8 \text { as its focus SDGs and mapped } \\
\text { them with their corporate actions. Trasus expects to move forward the work on the definition of its target and on the } \\
\text { territorialisation of the SDGs. }\end{array}$ \\
\hline Agua Corodobesas & $\begin{array}{l}\text { Agua Corodobesas, the water supply company in Córdoba, has been reporting to the Global Reporting Initiative for } \\
10 \text { years. The company is part of Global Compact and committed to ISO Standard } 26000 \text { on social responsibility. } \\
\text { Furthermore, Agua Corodobesas conducted a survey mapping its corporate actions to the SDGs. The survey } \\
\text { indicated that the company's actions contribute to most of the SDGs. The company's activities focus on drinking } \\
\text { water, both from a technical and social point of view, and aim at promoting decent work and partnerships to } \\
\text { achieve the SDGs. Agua Corodobesas also has ongoing co-operations with Banco de Alimentos and with Caritas, } \\
\text { in particular on SDGs } 1 \text { and } 2 \text {. In addition, the company is active in the field of education, both through its own } \\
\text { programmes and in partnership with other institutions. }\end{array}$ \\
\hline SIPSSA & $\begin{array}{l}\text { The medical company SIPSSA has been part of the UN Global Compact since 2015. In their last report, it aligned } \\
\text { its strategic plan with the SDGs. Due to the nature of the company, the focus is on health but most of its actions } \\
\text { contribute to several SDGs. SIPSSA also works with co-operatives on the SDGs, stressing the need to bring } \\
\text { together territorial actors to co-ordinate the projects undertaken by different actors on the SDGs. }\end{array}$ \\
\hline Loteria de Córdoba & $\begin{array}{l}\text { Córdoba's lottery Loteria de Córdoba has a very important social function. All the revenues of the lottery are used } \\
\text { to support the social projects of provincial governments, such as programmes on social development, equity and } \\
\text { justice. As provided by Law } 9505 \text {, taxes from the lottery go to Córdoba's social services programme PAICOR. The } \\
\text { lottery has launched two programmes to fight illegal gambling and another to promote responsible gambling. }\end{array}$ \\
\hline SANTEX & $\begin{array}{l}\text { The software development company SANTEX has so far mainly focused on CSR to address sustainability issues } \\
\text { but is now starting to develop strategies to broaden its work on sustainability. It has a strong focus on gender. } \\
\text { SANTEX has for instance started a process to equalise the salaries of male and female employees and started to } \\
\text { include the gender dimension in all of its analysis (SDG 5). Another key area of work is knowledge and technology } \\
\text { sharing. SANTEX supports students at secondary schools and promotes social enterprises. }\end{array}$ \\
\hline Espacio Abasto & $\begin{array}{l}\text { Espacio Abasto promotes green communities in Córdoba. Its goal is to create spaces for innovation and } \\
\text { sustainability in urban areas, including sustainable buildings. Espacio Abasto also works as a business incubator } \\
\text { and promotes urban transformation in the former market area. }\end{array}$ \\
\hline Banco de Córdoba & $\begin{array}{l}\text { The public-private bank Banco de Córdoba focuses on SDG } 8 \text { by supporting the implementation of policies and } \\
\text { programmes of the provincial government. The bank is also active in the area of financial education. Moreover, } \\
\text { SDG } 16 \text { is key for Banco de Córdoba in its work to prevent corruption and money laundering. }\end{array}$ \\
\hline
\end{tabular}

Source: OECD elaboration based on interviews conducted during the OECD fact-finding mission to Córdoba in 2019.

IARSE, the Argentinian Institute for Corporate Social Responsibility (Instituto Argentino de Responsabilidad Social Empresaria), which includes 170 member companies and institutions, has been promoting the SDGs with its members since their adoption in 2015. As part of its activities, IARSE carries 
out a self-assessment process to identify the links between the objectives of the companies and the SDGs. IARSE also investigates how to incorporate the SDGs into the companies' activities. Beyond that, IARSE's work focuses on awareness-raising activities on the 2030 Agenda, impact assessments as well as SDG training. In 2019, IARSE launched the network \#NetworkIARSE "ODS y Empresas: ¿Para qué? ¿Es posible? ¿Por qué es importante?", which carries out workshops with companies to underline the importance of the private sector in the achievement of the SDGs. It mostly acts as a forum to discuss how companies can become active on the 2030 Agenda and how SDGs can be incorporated into companies' business activities (IARSE, 2019 $\left.{ }_{[4]}\right]$.

The Industry Association of Córdoba (Unión Industrial de Córdoba, UIC) encourages member companies to integrate sustainability and SDGs into their core business model. The UIC, which groups all of the main industries of the province, has the objective of companies no longer addressing sustainability as a niche topic. Instead, it should be more visible and integrated into the core of the business model. In that context, the SDGs play an important role for the UIC as they make the topic of sustainability more visible. The association has therefore created a strategic axis on sustainability, whose key priorities are decent work, renewable energies, infrastructures and economic development. The association also has a food department working on SDG 2 Zero hunger. As of now, industries in Córdoba undertake actions related to all 17 SDGs but the business sector tends to suffer from the lack of co-ordination of public action, as different companies work with various sectoral ministries that have different and sometimes uncoordinated responsibilities. The lack of a common platform to co-ordinate the ongoing efforts of the private sector emerged as a challenge and a possible area of improvement for the future. The private sector is overall eager to further contribute to the efforts on SDGs but current efforts are still quite isolated.

\section{The need to institutionalise the process towards 2030 with the civil society}

The civil society is actively engaged in the 2030 Agenda in the province of Córdoba (Table 3.2). In comparison with the private sector, many civil society organisations are aware of the SDGs, are addressing several SDGs in their programmes of work and are linking their activities to the SDGs. Through the Córdoba SDG Forum, the province has established a mechanism for exchange among civil society actors. The forum was created in the context of the SDG territorialisation process in 2018 and represents an important gathering that contributes to increasing awareness of the 2030 Agenda among the civil society in the province. More than 50 organisations have been meeting once a month since 2018 to exchange their experiences and discuss possible alliances among a wide range of institutions working towards the 2030 Agenda. The establishment of the Córdoba SDG Forum was supported by the Córdoba Regional Faculty of the National Technological Universities and the Secretariat of Institutional Strengthening in 2018. The main objective of the forum is to generate a space for analysis, debate, dissemination, promotion and awareness of the SDGs. It targets managers and institutional decision-makers of companies, non-profit organisations and governments that apply or wish to contribute to the 2030 Agenda. Activities undertaken in 2020 included discussions about means to reduce inequality (SDG 10), the role of education in the context of COVID-19 (SDG 4) and the future of work in light of increasing automation (SDG 8) among others. 


\section{Table 3.2. Non-exhaustive list of civil society organisations in Córdoba active on the SDGs}

\begin{tabular}{|c|c|}
\hline Organisation & Main activities \\
\hline Un litro de leche por mes & $\begin{array}{l}\text { The foundation Un litro de leche por mes Córdoba is undertaking analysis on sustainable local development and } \\
\text { value chains, with a focus on intermediary institutions and SDG } 2 \text {. Five years ago, it launched a solidarity campaign } \\
\text { in the city of Alta Gracia. Neighbours were mobilised to help to provide milk to people in need. Its strategy focuses } \\
\text { on three pillars: snacks, garden and school support. It has many human resources but lacks financial resources. }\end{array}$ \\
\hline Fundación Avina & $\begin{array}{l}\text { Fundación Avina works in Latin America and Africa. SDG } 17 \text { is key for the foundation as partnerships for sustainable } \\
\text { development are at the core of its work. Fundación Avina's work on access to water, urban recycling, sustainable } \\
\text { cities, migration, political innovation, climate change as well as on the development of a Social Progress Index is } \\
\text { strongly related to the SDGs. }\end{array}$ \\
\hline Open data Córdoba & $\begin{array}{l}\text { Open data Córdoba is a civil society organisation promoting and disseminating open government practices, an } \\
\text { important contributory factor for SDG } 16 \text {. The organisation acts as a link between the government that wants to } \\
\text { promote transparency and open data on the one hand and citizens and the general public who need data on the } \\
\text { other. Open data Córdoba also monitors inflation and creates a link between supermarkets and the government, so } \\
\text { they can create indexes. They use technology to better connect governments and people. }\end{array}$ \\
\hline $\begin{array}{l}\text { Fundación par desarrollo } \\
\text { sostenible }\end{array}$ & $\begin{array}{l}\text { Fundación par desarrollo sostenible supports communities that are lagging, focusing on human rights and } \\
\text { sustainable development. The organisation is well aware of the SDGs and focuses its work on six of them: health, } \\
\text { gender equality, water and sanitation, sustainable communities, infrastructure and democracy. }\end{array}$ \\
\hline PARES & $\begin{array}{l}\text { PARES designs and implements comprehensive proposals on gender, citizenship and development. Its priorities are } \\
\text { people and the collaborative construction of knowledge and experiences in rights effectiveness processes. In } \\
\text { compliance with SDG 5, PARES created Olympia, an equality and diversity programme for companies that offers } \\
\text { diagnostic services, training, action plans and inclusive communication. PARES also developed Línea de Género en } \\
\text { ALTEC to mainstream the gender perspective in civic technology projects. For SDG 10, the organisation designed } \\
\text { and implemented the Program Interseccionalidad y Migraciones, supporting migrant and pro-migrant organisations } \\
\text { in the development of actions from the intersectional approach and ecology of knowledge to the promotion of } \\
\text { migration as a human right. Regarding SDG 11, PARES participates in Red Nuestra Córdoba, contributing a gender } \\
\text { and diversity perspective on citizenship and local political participation issues. PARES also supports Ensamble } \\
\text { Joven Feminista, the emergence of leadership and alliances of youth for youth in local and regional contexts, related } \\
\text { to technology, open government and ecofeminism (SDG 16). }\end{array}$ \\
\hline Córdoba global & $\begin{array}{l}\text { Córdoba global, an educational institution, focuses on professional training. Córdoba global is active on the SDGs, } \\
\text { analysing how regions outside of the province are using them. Its goal is to teach people what is happening outside } \\
\text { Córdoba and see how this can be used and adapted to the province. }\end{array}$ \\
\hline $\begin{array}{l}\text { SEF } \\
\text { (Sistema Económico } \\
\text { Fraterno) }\end{array}$ & $\begin{array}{l}\text { SEF's web platform - www.sef.com.ar - connects consumers and suppliers, facilitating consumption with positive } \\
\text { social and environmental impact. For each transaction carried out by users of the system, the platform provides a } \\
\text { donation for the incorporated social organisations. }\end{array}$ \\
\hline $\begin{array}{l}\text { Fundación Mayéutica } \\
\text { Argentina }\end{array}$ & $\begin{array}{l}\text { For the foundation, all SDGs are important, as partnerships for sustainable development are at the core of its work. It } \\
\text { seeks to promote cultural change according to the challenges presented by the } 2030 \text { Agenda. To promote the SDGs } \\
\text { to all citizens, it carries out events and webinars. In } 2020 \text {, its events were broadcasted by two radio stations in } \\
\text { Córdoba and a TV programme. }\end{array}$ \\
\hline Plurales Foundation & $\begin{array}{l}\text { The Plurales Foundation promotes and accompanies territorial and community development processes, networks } \\
\text { and actions and promotes economic, social, cultural and environmental rights (ESCR) from an environmental justice } \\
\text { and gender perspective. Plurales works towards SDGs } 1,2,5,6,13,15 \text { and } 16 \text {, and in particular co-ordinates an } \\
\text { initiative within the framework of the International Land Coalition "Land Initiative and SDG" including special } \\
\text { monitoring on the SDGs and their targets 1.4, 2.3, 5.a and 15.3. }\end{array}$ \\
\hline Orgaz Handmade & $\begin{array}{l}\text { Orgaz Handmade is an undertaking that supports the manual and craftwork of women. The organisation develops } \\
\text { productive capacities, trains women and thus aims to strengthen gender equality. Its focus is on SDG } 5 \text { : Gender } \\
\text { equality. Additional objectives of Orgaz Handmade include the financial inclusion of women and the reduction of } \\
\text { economic and patrimonial violence. }\end{array}$ \\
\hline Quality Argentina & $\begin{array}{l}\text { This organisation, based in the city of Córdoba, is dedicated to the management of intercultural projects that promote } \\
\text { cultural and human exchange between people from different countries through local insertion programmes in } \\
\text { Argentine institutions: schools, environmental projects, empowerment of women, among others, promoting } \\
\text { SDGs } 1-5,10,12,16 \text { and } 17 \text {. The programmes promote inclusion in all its aspects and also include projects for the } \\
\text { elderly. }\end{array}$ \\
\hline $\begin{array}{l}\text { Fundación para el } \\
\text { Desarrollo Sostenible } \\
\text { (FDS) }\end{array}$ & $\begin{array}{l}\text { The foundation seeks to accelerate the territorialisation of programmes and projects around sustainable } \\
\text { development. FDS focuses on SDGs } 4,10,11,12,13,15 \text { and } 17 \text {. Some examples of its programmes are the } \\
\text { Placing the Future for Urban Forestry project, the Sustainable Neighborhoods Program, the Circular Economy } \\
\text { Education Programme, urban gardens and recycling management technologies. FDS is furthermore active in the } \\
\text { field of territorial investigations of vulnerable communities, grassroots recycling and carries out awareness }\end{array}$ \\
\hline
\end{tabular}




\begin{tabular}{l|l}
\hline \multicolumn{1}{c}{ Organisation } & \multicolumn{1}{c}{ Main activities } \\
\hline $\begin{array}{l}\text { Argentine Public Health } \\
\text { Association }\end{array}$ & $\begin{array}{l}\text { The Argentine Public Health Association (AASAP) is a non-profit civil association. Aiming to contribute to the } \\
\text { (AASAP) }\end{array}$ \\
$\begin{array}{l}\text { common good, AASAP fosters respect for diverse identities, beliefs and traditions (cultural, religious, artistic, literary, } \\
\text { social, political or ethnic). AASAP has the objective to function as an interdisciplinary meeting place to contribute to } \\
\text { the development, execution and evaluation of public policies aimed at improving the health level of the population } \\
\text { considering the social determinants, the quality and access to the services that the population receives. AASAP } \\
\text { organises conferences, fora and seminars to debate and reflect on aspects of interest in the field of public health. }\end{array}$ \\
\hline $\begin{array}{l}\text { Fundación Banco de } \\
\text { Alimentos Córdoba } \\
\text { (Córdoba's foodbank) }\end{array}$ & $\begin{array}{l}\text { Córdoba's Food Bank is a non-governmental, non-denominational and non-profit organisation. The primary mission } \\
\text { of the institution is to reduce hunger among children and the elderly. Its main task is to solicit the donation of } \\
\text { foodstuffs and distribution to care centres. The food bank allows to collect and redistribute food suitable for human } \\
\text { consumption that companies cannot sell. }\end{array}$ \\
\hline
\end{tabular}

Table 3.3. Non-exhaustive list of universities and research institutes in Córdoba active on the SDGs

\begin{tabular}{|c|c|}
\hline Organisation & Main activities \\
\hline $\begin{array}{l}\text { National University of } \\
\text { Córdoba }\end{array}$ & $\begin{array}{l}\text { The National University of Córdoba co-ordinates the "Programa raíz" to support } 427 \text { municipalities in their municipal } \\
\text { management. The programme has the objective to develop processes that facilitate the generation of and access to } \\
\text { knowledge in order to solve problems in municipalities and communes of the province of Córdoba in order to } \\
\text { generate conditions for a better quality of life and an improvement of institutional quality. In this way, it seeks to } \\
\text { promote cultural change according to the challenges presented by the UN } 2030 \text { Agenda for local governments. The } \\
\text { programme focuses mainly on SDG } 11 \text { Sustainable cities and communities, SDG } 16 \text { related to strengthening } \\
\text { institutions through open government practices, and on SDG } 17 \text { Alliances to achieve the goals from laboratories of } \\
\text { Public Innovation. }\end{array}$ \\
\hline $\begin{array}{l}\text { Experimental Centre of } \\
\text { Economic Housing } \\
\text { (CEVE-CONICET) }\end{array}$ & $\begin{array}{l}\text { CEVE-CONICET is a research institute working on and experimenting with the development and transfer of } \\
\text { construction and management technologies for integral and sustainable habitats. CEVE adheres to numerous SDGs } \\
\text { (SDGs } 1,5,9,11,12 \text { and } 17) \text {. Related activities include studies on the use of urban and industrial waste for the } \\
\text { elaboration of construction components, programmes to ensure the full and effective participation of women in the } \\
\text { labour market and training on the positive economic and social effects of inclusion among others. }\end{array}$ \\
\hline $\begin{array}{l}\text { Centre for Chemical } \\
\text { Research and } \\
\text { Technology (CITeQ) - } \\
\text { CONICET - UTN }\end{array}$ & $\begin{array}{l}\text { The Centre for Chemical Research and Technology (CITeQ) is a research organisation whose objective is to carry } \\
\text { out scientific-technological research projects in the field of environmental remediation, valorisation of biomass and } \\
\text { fine chemicals, through sustainable processes and the development of adsorbents and solid catalysts. The main } \\
\text { research lines of CITeQ promote several of the SDGs: SDG } 5 \text { Gender equality; SDG } 6 \text { Clean water and sanitation; } \\
\text { SDG } 7 \text { Affordable and clean energy; SDG } 15 \text { Life on land; and SGD } 17 \text { Partnerships for the goals. }\end{array}$ \\
\hline $\begin{array}{l}\text { National Technological } \\
\text { University - Secretary of } \\
\text { Institutional Linking and } \\
\text { University Social } \\
\text { Responsibility }\end{array}$ & $\begin{array}{l}\text { The university develops programmes for the dissemination, analysis, debate and implementation of actions related to } \\
\text { the } 17 \text { SDGs in the areas of education, research and social leadership. Some of its programmes are: Sustainable } \\
\text { UTN (Universidad Tecnológica Nacional) where the SDGs are addressed in monthly conferences, the creation of the } \\
\text { Córdoba SDG Forum that brings together different institutional stakeholders from universities, companies, NGOs, } \\
\text { government and the } 2020-21 \text { co-ordination of the LAT SDG Network, present in } 13 \text { Latin American countries with } 70 \\
\text { members. }\end{array}$ \\
\hline Universidad Blas Pascal & $\begin{array}{l}\text { Blas Pascal University promotes sustainable management through training, research and management. In } 2020 \text {, it } \\
\text { proclaimed its Sustainability and USR (University Social Responsibility) policies aligned with the SDGs and the } 2030 \\
\text { Agenda. The university also promotes sustainable development practices through its bachelor's degree in } \\
\text { environmental management and its master's degree in sustainable development management. The institution is } \\
\text { moreover a signatory of UN Global Compact PRMEs (Principles of Responsible Management) and has released a } \\
\text { sustainability report aligned with the SDGs. }\end{array}$ \\
\hline Universidad Siglo 21 & $\begin{array}{l}\text { Universidad Siglo } 21 \text { is a private university headquartered in Córdoba committed to contributing to the SDGs in all } \\
\text { areas of its activity. Since 2017, it has presented a yearly sustainability report, adheres to the UN Global Compact } \\
\text { and pursues its } 10 \text { principles and the } 17 \text { SDGs. Regarding academic training, its inclusive and federal model } \\
\text { considers SDGs } 4 \text { and } 10 \text { by offering distance learning. }\end{array}$ \\
\hline $\begin{array}{l}\text { TREJO Association, } \\
\text { School of Law - National } \\
\text { University of Córdoba }\end{array}$ & $\begin{array}{l}\text { The students, graduates and sponsors of TREJO Association have the mission to promote humanist and democratic } \\
\text { research and values. Furthermore, they also connect and encourage different organisations of civil society, public } \\
\text { and private universities and political parties with a humanist vision to participate in comprehensive training for } \\
\text { students and citizens, taking into consideration a sociocritical approach and a world's innovative vision for the } \\
\text { sustainable and equitable development of future generations. LAB-TREJO (a research laboratory), whose main } \\
\text { objectives are the SDGs related to social issues, is working on SDGs } 4,5,10,11,16 \text { and } 17 \text {. }\end{array}$ \\
\hline
\end{tabular}


Civil society organisations as well as universities and research institutes support the localisation of the SDGs and stress its importance for the improvement of well-being in the province. The main opportunities and challenges for the civil society and universities related to the SDGs are:

- The institutionalisation of the process on the 2030 Agenda. The need to further integrate the dialogue on the SDGs into the policy-making process clearly emerges as a priority for the civil society and universities in Córdoba. There are some opportunities for them to discuss how to address the SDGs in Córdoba, notably the SDG Forum that was co-initiated by Córdoba's regional faculty of the National Technological Universities, but there is a need to further formalise those opportunities.

- The need to strengthen and support the SDG Forum that can help to co-ordinate the efforts of the civil society as well as of the other territorial stakeholders and raise awareness of the SDGs. Civil society organisations, universities and research institutions are developing several initiatives that are directly or indirectly targeting the SDGs and that can benefit from an intensified exchange between the different actors. In particular, the training opportunities and research projects offered and undertaken by the universities have the potential to be further exploited by civil society organisations.

- Making data and information easily available to citizens, including through the media. The availability of data and information on the 2030 Agenda is a crucial element on the pathway to achieving the SDGs. Against that background, the creation of Córdoba's Open Management Portal is an important step forward. In addition to these efforts, civil society, media and the press could play an important role in the distribution and sharing of information on the SDGs to broaden the target audience.

\section{A participatory matrix to identify the drivers of social inclusion in Córdoba}

\section{The process of the territorialisation of the SDGs in the province of Córdoba}

In order to use the 2030 Agenda as a policymaking tool, the province of Córdoba developed a matrix to identify synergies across the SDGs, which defined concrete strategic lines of action to contribute to the achievement of the social SDGs in Córdoba and promote social inclusion by means of a participatory process. During the year 2019, the province of Córdoba brought together various representatives of different territorial stakeholders, namely the government, academia, civil society and the private sector to develop strategies to adapt the 2030 Agenda to the provincial reality. The implementation of this localisation process of the SDGs took place in three stages, actively accompanied by the participation of the different stakeholder groups (see Figure 3.1 for a visual and Box 3.3 for details on the methodology):

- Prioritise: The first stage to validate and adapt the SDGs to the local context.

- Relate: The second stage to relate the prioritised goals and the selected SDGs to the 2030 Agenda as a whole and establish relationships between different priority goals.

- Think: The third stage to devise action plans and design concrete initiatives aimed at achieving the objectives and goals defined as priorities. 
Figure 3.1. SDG territorialisation process in Córdoba - Methodology and main priorities

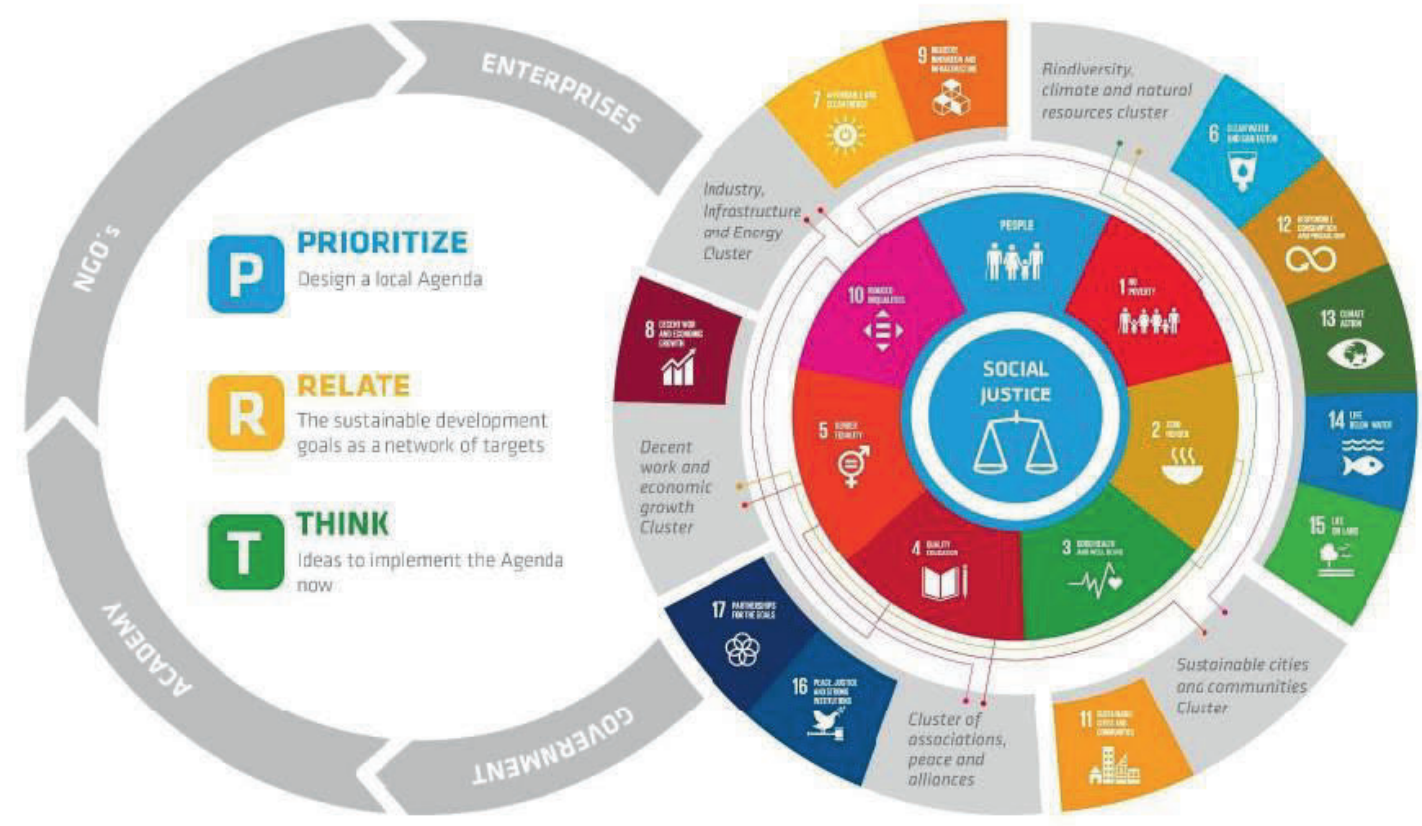

Source: Government of the Province of Córdoba (2020[5]), Informe Final Proceso de Territorializacion de ODS en la Provincia de Córdoba [Final Report Territorialisation Process of the SDGs in the Province of Córdoba].

\section{Box 3.3. Methodology for the SDG territorialisation process in the province of Córdoba, Argentina}

The province of Córdoba co-created the SDG territorialisation process jointly with representatives from the OECD, using methodologies based on design thinking tools and agile methods. In order to allow for a collaborative, inclusive and innovative process and to strengthen intersectoral alliances, the province carried out a series of awareness-raising and co-creation actions with the provincial stakeholders consisting of three different stages:

\section{- Prioritise: The first stage to validate and adapt the SDGs to the local context}

The prioritisation process started with a first round of interactive workshops to understand the interests and sectoral priorities of the provincial stakeholders (civil society organisations, academia, the private sector and provincial government actors) in relation to the 2030 Agenda. Prior to the workshops, the Secretariat of the government had pre-prioritised 35 targets. These were based on a selection of different targets for each SDG tailored to the local territory taking into account goals prioritised by the national government, competencies of the province of Córdoba and goals defined by the UN. In the workshops, the participants formed different working groups and received cards with the different SDG targets preselected by the secretariat. They were asked to either: i) approve the target as defined; ii) propose adjustments; iii) decline the suggested target; or iv) propose a new target. Overall, around 10 to 15 representatives per stakeholder group (34 in the case of the workshop with the provincial ministries) participated in the workshops. This first round of stakeholder consultations eventually led to an increase in the number of Córdoba's priority targets from the 35 preselected by the government to 42 . 
- Relate: The second stage to relate the prioritised goals and the selected SDGs to the 2030 Agenda as a whole and establish a relationship between priority goals

As a next step, the province developed a matrix linking the 42 priority targets with the 6 social SDGs in order to identify and measure synergies and trade-offs. In order to do so, the province organised a second round of workshops with the different stakeholder groups - this time jointly. Working groups with representatives from the different sectors were formed. The working groups had the task to link the main SDGs for the province to the 42 prioritised targets depending on their relationship - positive, neutral (no linkage) or negative. The participants could attribute +3 (indivisible), +2 (reinforcing), +1 (enabling), 0 (neutral), -1 (constraining), -2 (counteracting) or -3 points (cancelling) for each of the linkages. This was done first individually and then jointly as a working group based on discussions among the different members of the working group. The application of this matrix approach was inspired by the International Council for Science Guide to SDG Interactions: From Science to Implementation (2017[6]), which entails a scoring system of the SDGs and targets according to the positive, negative or neutral relationship between each other.

After the second workshop, the values that each participant assigned individually to the relationship between the 42 prioritised goals and the SDGs were recorded on a spreadsheet (see Table 3.4). In those cases where consensus was reached among the members of a working group on the value of the relationship between an SDG and a target, the participants agreed to assign that value for all individual scores among the members of the working group.

Table 3.4. Relationship matrix between prioritised targets and SDGs in Córdoba

\begin{tabular}{c|c|c|c|c|c|c}
\hline Prioritised targets & SDG 1 & SDG 2 & SDG 3 & SDG 4 & SDG 5 & SDG 10 \\
\hline 1.2 & +3 & +3 & +3 & +3 & +2 & +3 \\
\hline 1.3 & +3 & +3 & +3 & +2 & +3 & +3 \\
\hline 2.1 & +3 & +3 & +3 & +2 & +2 & +3 \\
\hline 2.3 & +2 & +3 & +2 & +1 & +2 & +2 \\
\hline $2 . a$ & +1 & +3 & +1 & 0 & +1 & +1 \\
\hline$\ldots$ & $\ldots$ & $\ldots$ & $\ldots$ & $\ldots$ & $\ldots$ & $\ldots$ \\
\hline 17.17 & +1 & +2 & +2 & +1 & +1 & +2 \\
\hline
\end{tabular}

Source: Government of the Province of Córdoba $(2020[5]$ ), Informe Final Proceso de Territorializacion de ODS en la Provincia de Córdoba [Final Report Territorialisation Process of the SDGs in the Province of Córdoba].

As a next step, participants at each table were weighted by the sector they represented in order to calculate the final values for the relationship between each SDG and target. Finally, the group average for each stakeholder group and the overall average of all four stakeholder groups were calculated. This weighted value of the relationship between each target and the SDG, ranging from +3 to -3 , was then rounded and tabulated in a 2-column matrix, with the rows containing the prioritised targets and the columns containing the 6 selected SDGs.

- Think: The third stage to elaborate action plans and design concrete initiatives aimed at achieving the objectives and goals defined as priorities

The objective of the third workshop was to identify in a multidimensional way specific projects and initiatives to achieve Córdoba's prioritised SDGs (SDGs 1-5 and 10). It built on an OECD review of methodologies (Le Blanc, 2015[7]; International Council for Science, 2017[6]; UN, 2017[8]; Niles and Fernando, 2017[9]; Griggs et al., 2014[10]) for mapping SDG interactions with the aim to develop an SDG matrix that could serve as a tool to define a Vision 2030 for the province of Córdoba. In preparation for the workshop, the General Secretariat of the 
Government had predefined several thematic clusters. These thematic clusters were: i) Industry, infrastructure and energy (SDGs 7 and 9); ii) Sustainable cities (SDG 11); iii) Decent work and sustainable economic growth (SDG 8); iv) Climate, natural resources, terrestrial and underwater life (SDGs 6, 12, 13, 14, 15); and v) Partnership, peace and alliances (SDGs 16 and 17). They were centred around the remaining 11 SDGs in order to analyse how these are linked to SDGs 1 to 5 and 10.

Five working groups of stakeholder representatives were formed and attributed to the different thematic clusters. The representatives of the stakeholder groups in each working group were selected on the basis of their knowledge and experience with the topics of the specific cluster. The discussions of the working groups in the third round of workshops started by defining the main problem related to the specific cluster they were assigned to. As a next step, the different groups had to come up with an objective linked to that problem and define the relevant stakeholder groups. Finally, they should propose different actions or projects related to one of the remaining 11 SDGs, which would contribute to the defined objective and thus have an impact on at least one of Córdoba's priority SDGs. The participants were thereby asked to take into consideration the matrix of relationships between targets and SDGs elaborated in the second workshop in order to come up with projects that create synergies and interlinkages among the different SDGs and Córdoba's targets.

Source: Government of the Province of Córdoba (2020[5] $)$, Informe Final Proceso de Territorializacion de ODS en la Provincia de Córdoba [Final Report Territorialisation Process of the SDGs in the Province of Córdoba]; Le Blanc, D. (2015[7]), "Towards integration at last? The sustainable development goals as a network of targets", https:/www.un.org/esa/desa/papers/2015/wp141_2015.pdf; International Council for Science $\left(2017_{[6]}\right), \quad$ A Guide to SDG Interactions: From Science to Implementation, https://council.science/wpcontent/uploads/2017/05/SDGs-Guide-to-Interactions.pdf; UN (2017[8] ), Integrated Approaches for Sustainable Development Goals Planning: The Case of Sustainable Development Goal 6 on Water and Sanitation, https://doi.org/10.18356/0ca8f8ae-en; Niles, N. and K. Fernando (2017[9]), "Implementing the SDGs - Responding to the challenges of interconnectivity and balance", Southern Voice Occasional Paper Series, Vol. 39; Griggs, D. et al. $\left(2014_{[10]}\right)$, "An integrated framework for sustainable development goals", http://dx.doi.org/10.5751/ES-07082-190449.

A first round of stakeholder consultations led to an increase in the number of Córdoba's priority targets from the 35 preselected by the government to $42 .{ }^{1}$ Overall, the stakeholder groups consisting of the government (represented by the Inter-Ministerial SDG board), academia, civil society and the private sector were in favour of adopting 34 of the 35 previously prioritised targets, however, highlighting the importance of different targets. Two additional targets were requested by members of the executive branch and added to the list, which consisted of 42 targets (34 of the preselected targets, 6 newly proposed target, 2 additional targets requested by the Inter-Ministerial SDG board) in the end (see Annex Table 3.A.1 for the full list). Including the gender/diversity perspective in a cross-cutting way across the SDGs emerged as one of the priorities for all four stakeholder groups. Waste and environment were topics raised as priorities by the representatives of the ministries and the private sector. Targets related to health emerged as priorities relevant to both universities and companies. Civil society representatives put particular emphasis on issues of transparency and access to public information. The process finally resulted in a single comprehensive prioritisation of the vision of all stakeholders.

A matrix analysis revealed the key drivers to achieve the six SDGs prioritised by the province in relation to its priority on social inclusion. Through a matrix relationship analysis conducted in a second round of workshops (see Box 3.3 for details), the province of Córdoba was able to extract the most important thematic areas for the achievement of the 2030. As expected, the strongest interlinkages were found among the dimension "People". Tackling SDG 2 Zero hunger for instance was perceived to be a fundamental contributing factor for the achievement of SDG 1 No poverty. However, the matrix also revealed strong interlinkages between sustainable cities (SDG 11), health (SDG 3) and poverty (SDG 1). 
The thematic areas that were considered to be most relevant for the achievement of the six priority SDGs are illustrated in Figure 3.2.

Figure 3.2. Key drivers for the achievement of Córdoba's prioritised SDGs

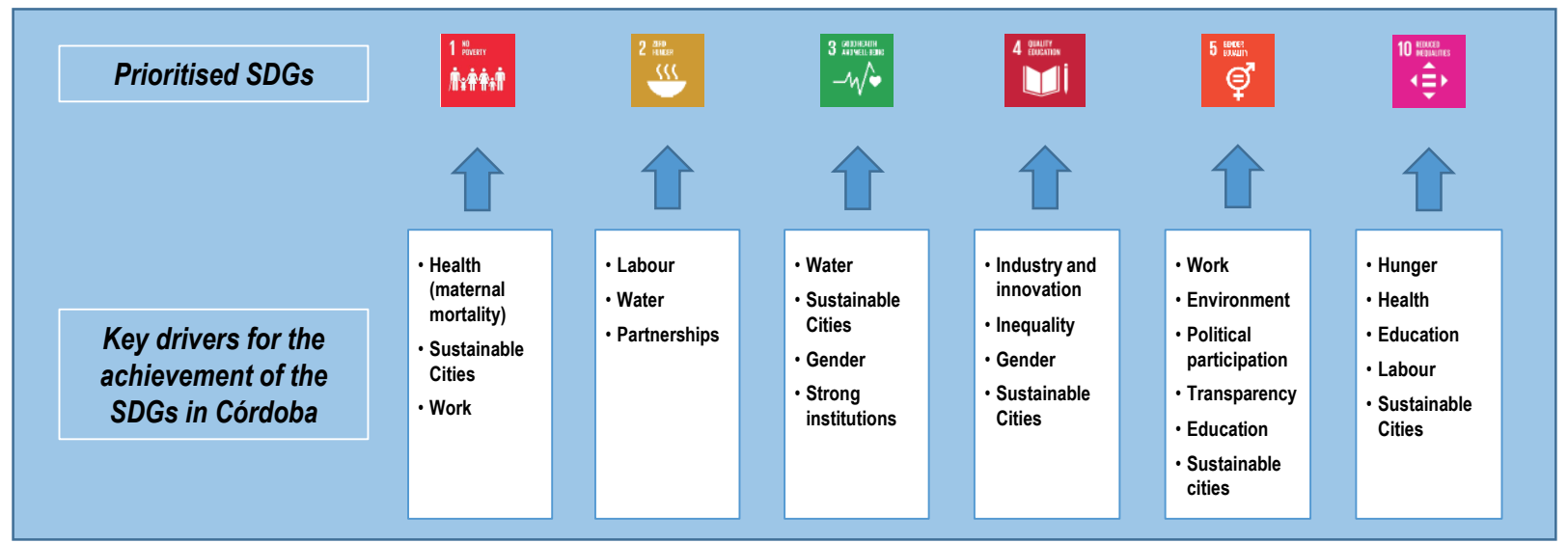

Source: OECD elaboration based on the outcomes of the second stakeholder workshop.

An illustration of the interlinkages between Córdoba's priority targets and SDG 1 can be found in Figure 3.3. For all the results, it was decided to visualise the relationship between the goals of the People dimension and the goals of the other dimensions (Planet, Prosperity, Partnerships and Peace), in order to see how the 42 intersectoral priority targets drive the agenda towards its achievement (Figure 3.4).

Figure 3.3. Interlinkages between Córdoba's priority targets and SDG 1

SDG 1

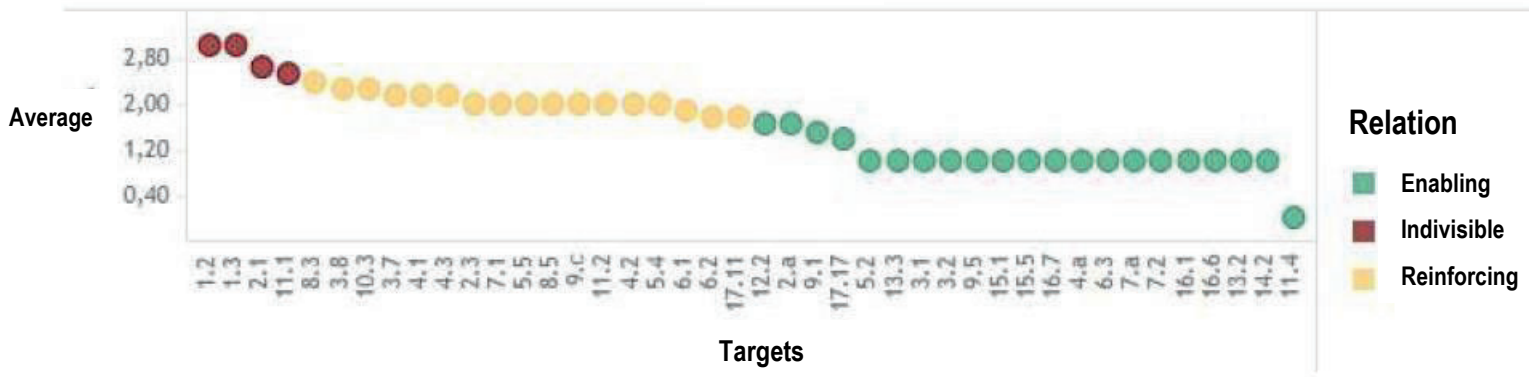

Source: Government of the Province of Córdoba (2020[5]), Informe Final Proceso de Territorializacion de ODS en la Provincia de Córdoba [Final Report Territorialisation Process of the SDGs in the Province of Córdoba].

The third workshop led to the development of concrete strategic lines of action to contribute to the achievement of the social SDGs in Córdoba and promote social inclusion. The main lines of actions agreed on by the different working groups were the following:

- Industry, infrastructure and energy: Build a vision of multidimensional economic development associated with the territory.

- Sustainable cities: Reduce the housing deficit through the contribution of sustainable construction.

- Decent work and sustainable economic growth: Generate sustainable work for the most excluded.

- Climate, natural resources, terrestrial and underwater life: Sustainable water management.

- Partnerships, peace and alliances: Deepen the process of co-ordination and transparency. 
Figure 3.4. Relationship between the 42 prioritised targets and the 6 SDGs selected as priorities by the province of Córdoba
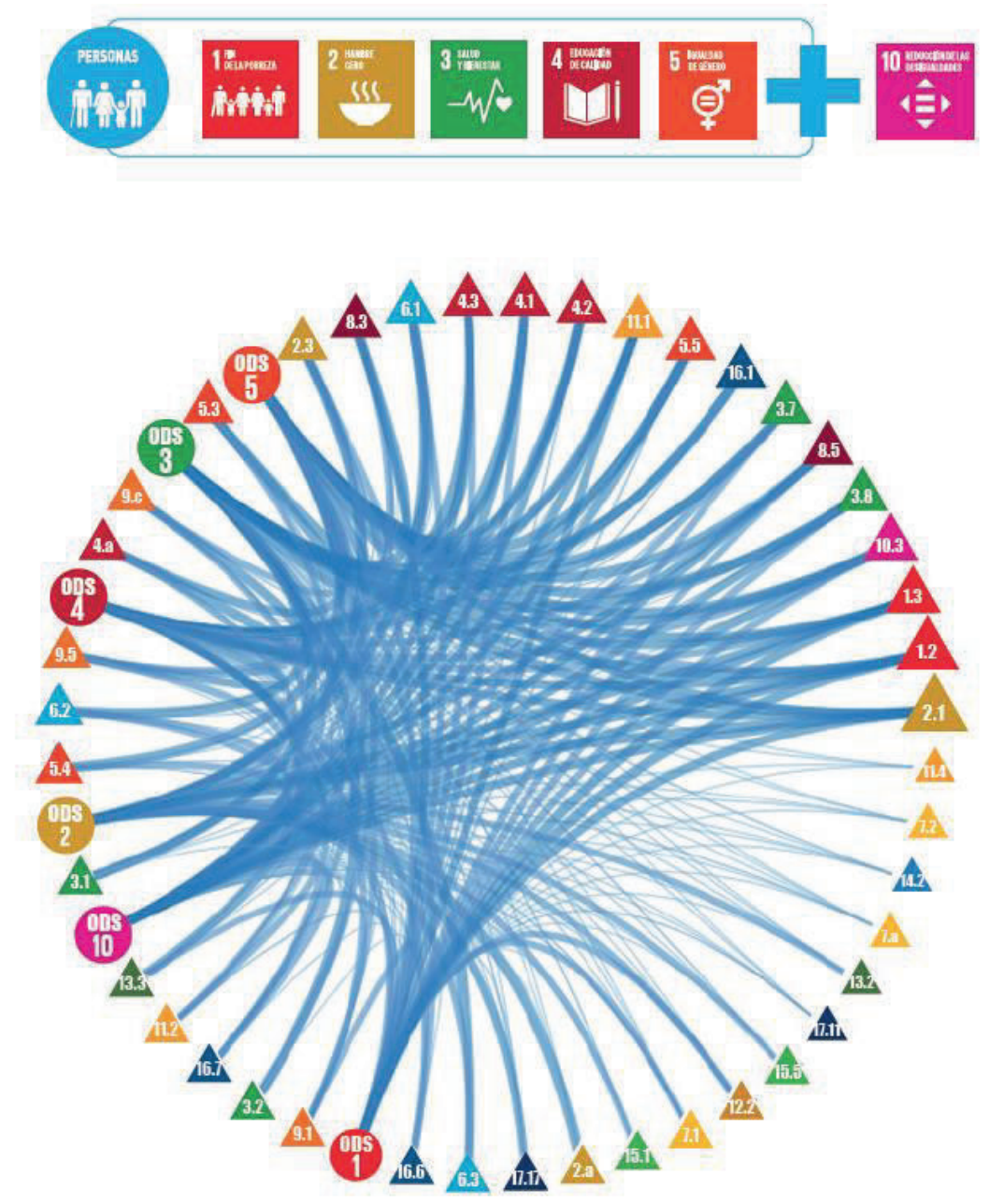

Source: Government of the Province of Córdoba (2020[5]], Informe Final Proceso de Territorializacion de ODS en la Provincia de Córdoba [Final Report Territorialisation Process of the SDGs in the Province of Córdoba].

The working group on SDG 8 (Cluster "Decent work and sustainable economic growth") for instance defined the lack of sustainable and inclusive work as the main problem to tackle to achieve the objective of generating sustainable work for the most excluded. The main stakeholder groups to be addressed were defined as the youth, people with disabilities, women and entrepreneurs among others. Possible actions proposed included encouraging companies with tax benefits to assist entrepreneurs and project incubators, developing training programmes that encourage the labour market integration of young people through universities and redesigning credit lines. An overview of the main discussions and the strategic line of work that each working group can be found in Table 3.5.

Table 3.5. Main outcomes of the third workshop on the territorialisation of the SDGs in Córdoba

\begin{tabular}{l|c|c|c}
\hline \multicolumn{1}{c|}{ Cluster } & $\begin{array}{c}\text { SDGs } \\
\text { covered }\end{array}$ & Main discussions & $\begin{array}{c}\text { Possible strategic line of work } \\
\text { agreed on }\end{array}$ \\
\hline $\begin{array}{l}\text { Industry, infrastructure } \\
\text { and energy }\end{array}$ & $\begin{array}{l}\text { The actors who participated in this working group focused their } \\
\text { main discussions on the economic development of the } \\
\text { province. The key concepts discussed were sustainable }\end{array}$ & $\begin{array}{l}\text { Build a vision of multidimensional } \\
\text { economic development associated } \\
\text { with the territory of the province of }\end{array}$ \\
\hline
\end{tabular}




\begin{tabular}{|c|c|c|c|}
\hline Cluster & $\begin{array}{l}\text { SDGs } \\
\text { covered }\end{array}$ & Main discussions & $\begin{array}{c}\text { Possible strategic line of work } \\
\text { agreed on }\end{array}$ \\
\hline & & $\begin{array}{l}\text { economic growth, the use of renewable energies, resilient } \\
\text { infrastructure and the development of projects in collaboration } \\
\text { with the territorial planning department. The focus of the } \\
\text { debate was mainly on SDG } 9 \text { since it is more closely related to } \\
\text { the People dimension as a whole. } \\
\text { Taking into account the matrix of the relationships between the } \\
\text { prioritised goals and the SDGs of the People dimension, } \\
\text { developed in the second workshop, SDGs } 1 \text { and } 4 \text { were found } \\
\text { to be of particular relevance for this strategic line of action. }\end{array}$ & Córdoba \\
\hline Sustainable cities & & $\begin{array}{l}\text { The actors of this working group presented a diversity of } \\
\text { proposals focused on SDG } 11 \text {. The key concepts that underpin } \\
\text { the proposal of reducing the housing deficit through the } \\
\text { contribution of sustainable construction are the use of waste as } \\
\text { a raw material for housing, land use, environmental } \\
\text { decontamination and the circular economy. } \\
\text { Taking into account the matrix of the relationships between the } \\
\text { prioritised goals and the SDGs of the People dimension, } \\
\text { developed in the second workshop, SDGs } 1 \text { and } 10 \text { were } \\
\text { found to be of particular relevance for this strategic line of } \\
\text { action. }\end{array}$ & $\begin{array}{l}\text { Reduce the housing deficit through } \\
\text { the contribution of sustainable } \\
\text { construction }\end{array}$ \\
\hline $\begin{array}{l}\text { Decent work and } \\
\text { sustainable economic } \\
\text { growth }\end{array}$ & 集 & $\begin{array}{l}\text { The discussions of this working group revolved around the } \\
\text { concepts of equal access to work for women, youth, people } \\
\text { with disabilities, sustainable work and the promotion of } \\
\text { entrepreneurship. } \\
\text { Taking into account the matrix of the relationships between the } \\
\text { prioritised goals and the SDGs of the People dimension, } \\
\text { developed in the second workshop, SDGs } 5 \text { and } 10 \text { were } \\
\text { found to be of particular relevance for this strategic line of } \\
\text { action. }\end{array}$ & $\begin{array}{l}\text { Generate sustainable work for the } \\
\text { most excluded }\end{array}$ \\
\hline $\begin{array}{l}\text { Climate, natural } \\
\text { resources, terrestrial } \\
\text { and underwater life }\end{array}$ & 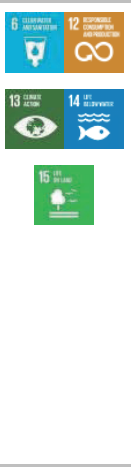 & $\begin{array}{l}\text { Since this cluster includes all the aspects of the dimension } \\
\text { Planet, the working group's discussions focused on the SDGs } \\
\text { that have the closest relationship with the dimension People. } \\
\text { Building on the results of the analysis of the relationship matrix } \\
\text { in the second workshop, the participants thus put particular } \\
\text { emphasis on the importance of water and its management } \\
\text { (SDG 6). The following key concepts were discussed: access } \\
\text { to drinking water, preservation of basins and water sources, } \\
\text { healthcare and well-being, and mitigation of climate change. } \\
\text { Taking into account the matrix of the relationships between the } \\
\text { prioritised goals and the SDGs of the People dimension, } \\
\text { developed in the second workshop, SDGs } 2 \text { and } 3 \text { were found } \\
\text { to be of particular relevance for this strategic line of action. }\end{array}$ & Sustainable water management \\
\hline $\begin{array}{l}\text { Partnerships, peace } \\
\text { and alliances }\end{array}$ & ${ }^{10}$ & $\begin{array}{l}\text { The discussions of this working group focused on the roles and } \\
\text { relationships of different actors involved in the } 2030 \text { Agenda } \\
\text { resulting from their actions and communication. The key } \\
\text { concepts that emerged were the transparency of institutions, } \\
\text { the participation of all stakeholders in projects related to the } \\
2030 \text { Agenda and the need to ensure that the process of its } \\
\text { implementation is carried out in a transparent manner. } \\
\text { The SDGs used as examples to outline actions related to this } \\
\text { strategic line of were SDGs } 1 \text { and } 2 \text {. However, this proposal for } \\
\text { articulation and transparency has an impact on all the SDGs of } \\
\text { the People dimension. }\end{array}$ & $\begin{array}{l}\text { Deepen the process of co-ordination } \\
\text { and transparency }\end{array}$ \\
\hline
\end{tabular}

Source: Government of the Province of Córdoba (2020[5]), Informe Final Proceso de Territorializacion de ODS en la Provincia de Córdoba [Final Report Territorialisation Process of the SDGs in the Province of Córdoba]. 


\section{The SDGs as a means to respond to interlinked sustainability challenges in Córdoba}

The stakeholder process to develop the matrix and the strategic lines of action revealed how the SDGs can be used as a means to respond to interlinked sustainability challenges in Córdoba, detected relevant areas of work for the SDGs and potential collaborations between different government departments. For the province of Córdoba, the development of the matrix of relationships between local targets and the SDGs provided valuable analysis and inputs to identify crucial areas of work for the implementation of the 2030 Agenda. It also allowed the province to observe the territorial reality from a variety of stakeholder perspectives. The five clusters and strategic lines of actions emerging from this process provide an opportunity to reflect on how the SDGs can help to generate synergies between different provincial policy challenges and targets such as housing, the creation of job opportunities and sustainable water management.

Sustainable construction based on waste recycling could be a tool to tackle the housing and recycling deficit at the same time. Housing is an area where the province of Córdoba is facing various challenges with the average number of available rooms per person lower than the OECD average, less than a third of the province's population satisfied with the affordability of housing and the population growth rate already higher than the built-up area growth rate. The housing deficit hence emerged as one of the main concerns regarding the achievement of SDG 11. Lack of available land and land degradation are two of the main contributory factors for the housing deficit in Córdoba. Considering a projected population increase by more than 30\% between 2010 and 2040 (Figure 3.5), there are synergies between the housing situation and the environmental dimension of the 2030 Agenda in Córdoba. Sustainable construction utilising recycled and reusable material are a means to tackle both the amount of waste produced in the province (SDG 12) and the lack of housing (SDG 11) at the same time.

Figure 3.5. Population development in the province of Córdoba (1960-2040)

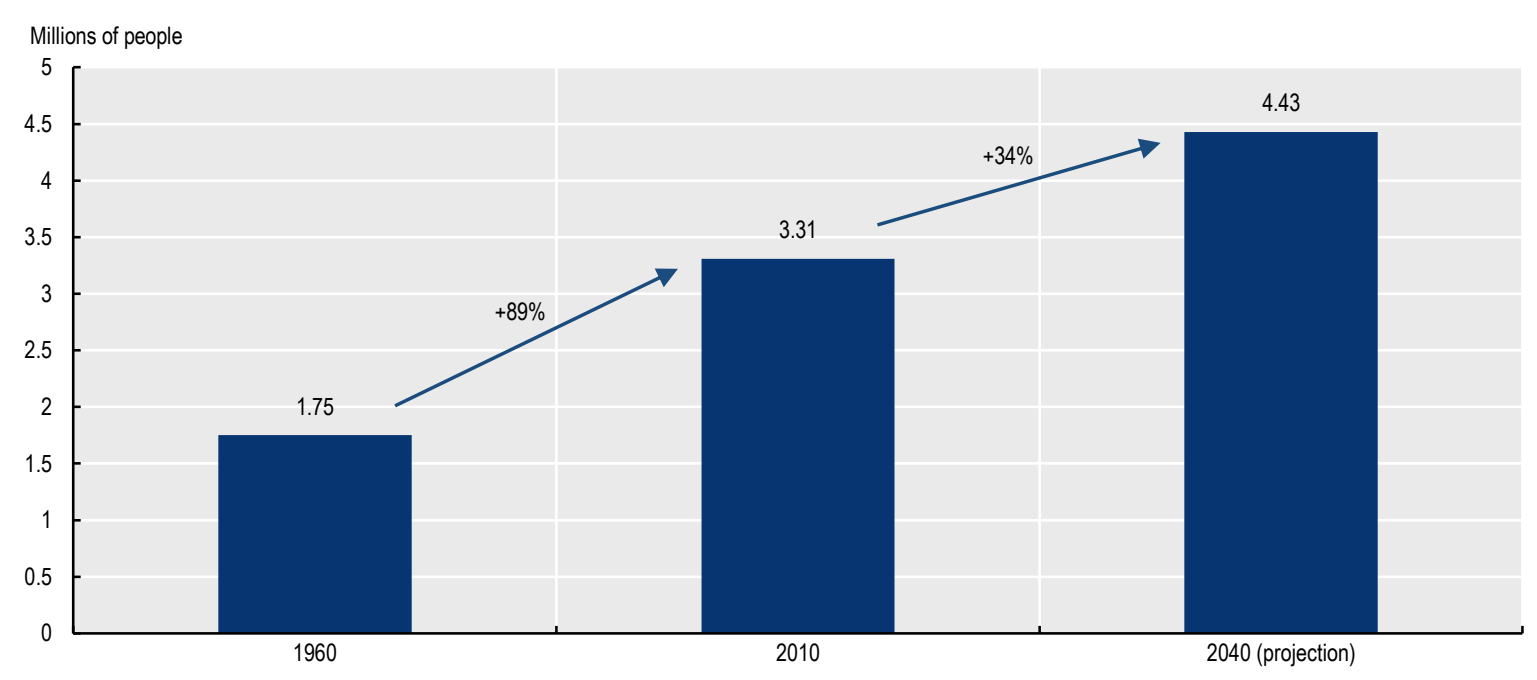

Source: OECD elaboration based on General Directorate of Statistics and Censuses (2014[11]). (2014), Volumen, Estructura y Dinámica Poblacional de la Provincia de Córdoba [Volume, Structure and Population Dynamics of the Province of Córdoba], https://datosestadistica.cba.gov.ar/dataset/9d0f69fb-04bc-4bc3-ad11-ee3183059815/resource/2ca0bb51-acac-4848-b633c8fa35ab7851/download/desd_informe_poblacion.pdf.

The lack of job creation emerged as one of the main challenges for the province. The situation on the labour market is particularly tense for youth: one out of four young people in Córdoba does not have a job. Moreover, women are often excluded from the paid labour market as they do unpaid domestic work instead and their unemployment rate is more than 3.5 percentage points higher than the equivalent rate for men. 
As revealed by the matrix analysis in the stakeholder workshops, the creation of jobs and decent work is one of the most relevant targets for the achievement of Córdoba's priority SDG 1 Zero poverty and SDG 5 Gender equality. Strengthening the integration of women and youth into the labour market has a lot of synergetic potential with the People dimension of the 2030 Agenda. It could contribute to a decrease in female and youth poverty as these are the groups that are more at risk of falling into and remaining in poverty (UN Women, 2018[12]).

Water management is a key priority for sustainable development in the province of Córdoba. In terms of environmental and climate-related challenges, the regional stakeholders identified a high degree of synergies between the first three targets of SDG 6 (universal and equitable access to safe and affordable drinking water; access to adequate and equitable sanitation; and improved water quality) and SDG 2 Zero hunger and SDG 3 Good health and well-being. Using these interlinkages as a starting point, the participants defined sustainable water management as a crucial topic for the province. Water management is particularly relevant for Córdoba as it is a landlocked province but close to $4 \%$ of its area are covered by water bodies, notably through its access to the Lago Salinas Grandes and the Laguna Mar Chiquita. It is also an important topic to address as Córdoba belongs to the $2 \%$ of OECD regions that have registered the largest losses in water body volumes (in percentage points of total water bodies) between 1992 and 2015. Achieving SDG Target 14.2 to sustainably manage and protect marine and coastal ecosystems could facilitate the long-term access to water resources, thus having a positive impact on SDG 6, which as the stakeholder workshop has pointed out, is strongly connected to SDGs 2 and 3. Going beyond the topic of water management, the participants identified SDG Target 13.3 about climate change education as a cross-cutting issue that is the prerequisite for all climate change policies and mitigation strategies.

A participatory approach and a higher degree of policy co-ordination could help to ensure food security and good nutrition for all. Food security is an important development issue for a region such as the province of Córdoba whose agricultural sector contributes a large share (more than $20 \%$ ) to the regional gross domestic product (GDP). The cluster on partnerships, peace and alliance therefore focused on the interlinkages between SDGs 16 and 17 on the one hand and SDG 2 Food Security on the other. SDG Targets 16.6 "to develop effective, accountable and transparent institutions", 16.7 "to ensure responsive, inclusive, participatory and representative decision-making" and 17.17 "to encourage and promote effective public, public-private and civil society partnerships, building on the experience and resourcing strategies of partnerships" were mentioned as having a strong potential impact on the progress made on the reduction of hunger (SDG 2). In that context, neighbourhood councils and neighbourhood centres in Córdoba were mentioned as successful examples of participatory approaches already applied in the province. In these neighbourhood councils, local residents come together to discuss challenges and possible actions and priorities to improve neighbourhood safety in collaboration with the responsible ministries.

The lack of an updated multidimensional development vision is a key challenge for Córdoba. The stakeholders argued in favour of developing a regional development strategy and vision with a broader focus than economic growth. The SDGs offer a holistic framework to develop such comprehensive regional development policies. Through the first two sessions of its stakeholder workshops, Córdoba had already identified strong interlinkages between different targets and regional development priorities, for instance, a strong connection between the targets of SDG 9 (particularly: reliable, sustainable and resilient infrastructure; enhancing scientific research and upgrading the technological capabilities of industrial sectors; and increasing access to information and communications technologies) and the SDGs 1 No Poverty, SDG 2 Zero Hunger, SDG 3 Good Health and Well-Being, SDG 4 Quality Education and SDG 5 Gender Equality . 


\section{Annex 3.A. List of SDG targets adapted to the context of the province of Córdoba}

\section{Annex Table 3.A.1. List of the 42 SDG targets adapted to the context of the province of Córdoba}

\begin{tabular}{|c|c|c|}
\hline SDG & Target & Description \\
\hline \multirow{2}{*}{ intih } & 1.2 & By 2030 , to reduce the proportion of people living in poverty in all its dimensions. \\
\hline & 1.3 & $\begin{array}{l}\text { Implement appropriate social protection systems and measures for all, including floors, and by } 2030 \text { achieve substantial } \\
\text { coverage of the poor and the vulnerable. }\end{array}$ \\
\hline \multirow[t]{3}{*}{ 필 } & 2.1 & $\begin{array}{l}\text { By 2030, substantially reduce and hunger and ensure access by all people, in particular the poor and people in vulnerable } \\
\text { situations, including infants, to safe, nutritious and sufficient food all year round. }\end{array}$ \\
\hline & 2.3 & $\begin{array}{l}\text { By } 2030 \text {, double the agricultural productivity and incomes of small-scale food producers, in particular women, indigenous } \\
\text { peoples, family farmers, pastoralists and fishers, including through secure and equal access to land, other productive } \\
\text { resources and inputs, knowledge, financial services, markets and opportunities for value addition and non-farm } \\
\text { employment. }\end{array}$ \\
\hline & 2.a & $\begin{array}{l}\text { Increase investments in rural infrastructure and logistics, agricultural research and extension services, technological } \\
\text { development, and plant and animal gene banks in order to improve agricultural production capacity, ensure the } \\
\text { environment and favouring less developed regions. }\end{array}$ \\
\hline \multirow{4}{*}{3} & 3.1 & By 2030 , reduce the global maternal mortality ratio. \\
\hline & 3.2 & By 2030 , end preventable deaths of new-borns and children under 5 years of age. \\
\hline & 3.7 & $\begin{array}{l}\text { By } 2030 \text {, ensure universal access to sexual and reproductive healthcare services, including family planning, information } \\
\text { and education, and the integration of reproductive health into strategies and programmes of the province. }\end{array}$ \\
\hline & 3.8 & $\begin{array}{l}\text { Achieve universal health coverage, including financial risk protection, access to quality essential healthcare services and } \\
\text { access to safe, effective, quality and affordable essential medicines and vaccines for all. }\end{array}$ \\
\hline \multirow[t]{4}{*}{ 4ail } & 4.1 & $\begin{array}{l}\text { By } 2030 \text {, ensure that all girls and boys complete free, equitable and quality primary and secondary education leading to } \\
\text { relevant and effective learning outcomes. }\end{array}$ \\
\hline & 4.2 & $\begin{array}{l}\text { By } 2030 \text {, ensure that all girls and boys have access to quality early childhood development, care and pre-primary } \\
\text { education so that they are ready for primary education. }\end{array}$ \\
\hline & 4.3 & $\begin{array}{l}\text { 2030, ensure equal access for all women and men to affordable and quality technical, vocational and tertiary education, } \\
\text { including university. }\end{array}$ \\
\hline & 4.a & $\begin{array}{l}\text { Build and upgrade education facilities that are child, disability and gender sensitive and provide safe, non-violent, } \\
\text { inclusive and effective learning environments for all. }\end{array}$ \\
\hline \multirow[t]{3}{*}{ 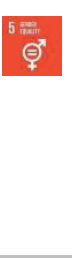 } & 5.2 & $\begin{array}{l}\text { Eliminate all forms of gender violence in the public and private spheres, including trafficking and sexual and other types of } \\
\text { exploitation. }\end{array}$ \\
\hline & 5.4 & $\begin{array}{l}\text { Recognise and value unpaid care and domestic work through the provision of public services, infrastructure and social } \\
\text { protection policies and the promotion of shared responsibility within the household and the family. }\end{array}$ \\
\hline & 5.5 & $\begin{array}{l}\text { Ensure women's full and effective participation and equal opportunities for leadership at all levels of decision-making in } \\
\text { political, economic and public life. }\end{array}$ \\
\hline \multirow{3}{*}{7} & 6.1 & By 2030 , achieve universal and equitable access to safe and affordable drinking water for all. \\
\hline & 6.2 & By 2030 , achieve access to adequate and equitable sanitation and hygiene for all. \\
\hline & 6.3 & $\begin{array}{l}\text { By } 2030 \text {, improve water quality by reducing pollution, eliminating dumping and minimising release of hazardous chemicals } \\
\text { and materials, halving the proportion of untreated wastewater and substantially increasing recycling and safe reuse. }\end{array}$ \\
\hline \multirow{3}{*}{$7 \overline{0}$} & 7.1 & By 2030, ensure universal access to affordable, reliable and modern energy services. \\
\hline & 7.2 & By 2030 , increase substantially the share of renewable energy in the energy mix. \\
\hline & 7.a & By 2030 , enhance local investment in research and projects related to renewable energies. \\
\hline
\end{tabular}




\begin{tabular}{|c|c|c|}
\hline SDG & Target & Description \\
\hline \multirow[t]{2}{*}{ 行 } & 8.3 & $\begin{array}{l}\text { Promote development-oriented policies that support productive activities, decent job creation, entrepreneurship, creativity } \\
\text { and innovation, and encourage the formalisation and growth of micro-, small- and medium-sized enterprises, including } \\
\text { through access to financial services. }\end{array}$ \\
\hline & 8.5 & $\begin{array}{l}\text { By } 2030 \text {, achieve full and productive employment and decent work for all people, including for young people and persons } \\
\text { with disabilities, and equal pay for work of equal value. }\end{array}$ \\
\hline \multirow[t]{3}{*}{8} & 9.1 & $\begin{array}{l}\text { Develop quality, reliable, sustainable and resilient infrastructure, to support economic development and human well-being, } \\
\text { with a focus on affordable and equitable access for all. }\end{array}$ \\
\hline & 9.5 & $\begin{array}{l}\text { Enhance scientific research, upgrade the technological capabilities of industrial sectors in all regions in the province, } \\
\text { including encouraging innovation and substantially increasing the number of research and development workers and } \\
\text { public and private research and development spending by } 2030 \text {. }\end{array}$ \\
\hline & $9 . c$ & $\begin{array}{l}\text { Significantly increase access to information and communications technology and strive to provide universal and affordable } \\
\text { access to the Internet in the least-developed areas in the province by } 2020 \text {. }\end{array}$ \\
\hline & 10.3 .1 & $\begin{array}{l}\text { Empower and promote the social, economic and political inclusion of all, irrespective of age, gender, disability, race, } \\
\text { ethnicity, origin, religion or economic or other status, ensuring equal opportunity and reduce inequalities of outcome, } \\
\text { including by eliminating discriminatory laws, policies and practices and promoting appropriate legislation, policies and } \\
\text { action in this regard. }\end{array}$ \\
\hline & 11.1 & $\begin{array}{l}\text { By 2030, ensure access for all to adequate, safe and affordable housing and basic services and upgrade least-developed } \\
\text { neighbourhoods. }\end{array}$ \\
\hline & 11.2 & $\begin{array}{l}\text { By 2030, provide access to safe, affordable, accessible and sustainable transport systems for all, improving road safety, } \\
\text { notably by expanding public transport, with special attention to the needs of those in vulnerable situations, women, } \\
\text { children, persons with disabilities and older persons. }\end{array}$ \\
\hline & 11.4 & Strengthen efforts to protect and safeguard the world's cultural and natural heritage. \\
\hline & 12.2 & By 2030 , achieve sustainable management and efficient use of natural resources. \\
\hline \multirow{2}{*}{8} & 13.2 & Integrate climate change measures into policies, strategies and planning at the province level. \\
\hline & 13.3 & $\begin{array}{l}\text { Improve education, awareness-raising and human and institutional capacity on climate change mitigation, adaptation, } \\
\text { impact reduction and early warning. }\end{array}$ \\
\hline & 14.2 & $\begin{array}{l}\text { By } 2020 \text {, sustainably manage and protect marine and coastal ecosystems to avoid significant adverse impacts, including } \\
\text { by strengthening their resilience, and take action for their restoration in order to achieve healthy and productive rivers, } \\
\text { lakes and lagoons. }\end{array}$ \\
\hline \multirow[t]{2}{*}{$\underline{\underline{s}}$} & 15.1 & $\begin{array}{l}\text { By 2030, ensure the conservation, restoration and sustainable use of terrestrial and inland freshwater ecosystems and } \\
\text { their services, in particular forests, wetlands, mountains and drylands. }\end{array}$ \\
\hline & 15. & $\begin{array}{l}\text { Take action to reduce the degradation of natural habitats, halt the loss of biodiversity and protect and prevent the } \\
\text { extinction of threatened species. }\end{array}$ \\
\hline \multirow{3}{*}{ Y. } & 16.1 & Significantly reduce all forms of violence and related death rates. \\
\hline & 16.6 & Develop and improve effective, accountable and transparent institutions at all levels. \\
\hline & 16.7 & Ensure responsive, inclusive, participatory and representative decision-making at all levels. \\
\hline \multirow[t]{2}{*}{17} & 17.11 & $\begin{array}{l}\text { Significantly increase the exports, in particular with special emphasis on adding value, diversification of markets and } \\
\text { support for small- and medium-sized companies. }\end{array}$ \\
\hline & 17.17 & $\begin{array}{l}\text { Encourage and promote effective public, public-private and civil society partnerships, building on the experience and } \\
\text { resourcing strategies of partnerships. }\end{array}$ \\
\hline
\end{tabular}

Source: Government of the Province of Córdoba (2020[5]], Informe Final Proceso de Territorializacion de ODS en la Provincia de Córdoba [Final Report Territorialisation Process of the SDGs in the Province of Córdoba]. 


\section{References}

General Directorate of Statistics and Censuses (2014), Volumen, Estructura y Dinámica Poblacional de la Provincia de Córdoba [Volume, Structure and Population Dynamics of the Province of Córdoba], Province of Córdoba, https://datosestadistica.cba.gov.ar/dataset/9d0f69fb-04bc-4bc3-ad11ee3183059815/resource/2ca0bb51-acac-4848-b633c8fa35ab7851/download/desd informe poblacion.pdf.

Government of the Province of Córdoba (2020), Informe Final Proceso de Territorializacion de ODS en la Provincia de Córdoba [Final Report Territorialisation Process of the SDGs in the Province of Córdoba].

Government of the Province of Córdoba (2019), "Córdoba hacia el 2030 - Tercer taller, Los Objetivos de Desarrollo Sostenible en el contexto local [Cordoba towards 2030 - Third workshop, The Objectives of Sustainable Development in the local context]".

Government Secretariat for the Modernisation of the Nation, Argentina (2019), Argentina Abierta, Mapa federal de políticas públicas sobre Gobierno [Open Argentina, Federal Map of Public Policies on Government], https://www.argentina.gob.ar/sites/default/files/argentina abierta edicion digital.pdf.

Griggs, D. et al. (2014), "An integrated framework for sustainable development goals", Ecology and Society, Vol. 19/4, p. 49, http://dx.doi.org/10.5751/ES-07082-190449.

IARSE (2019), "IARSE organizó el primer workshop de trabajo sobre ODS y empresas [IARSE organised the first workshop on the SDGs and companies]", http://www.iarse.org/noticias/eventosiarse/iarse-organizo-el-primer-workshop-de-trabajosobre-ods-y-empresas (accessed on 15 September 2020).

International Council for Science (2017), A Guide to SDG Interactions: From Science to Implementation, International Council for Science, Paris, https://council.science/wpcontent/uploads/2017/05/SDGs-Guide-to-Interactions.pdf.

Le Blanc, D. (2015), "Towards integration at last? The sustainable development goals as a network of targets", DESA Working Paper, Vol. 141/ST/ESA/2015/DWP/141, https://www.un.org/esa/desa/papers/2015/wp141 2015.pdf.

Ministry of Modernisation of the Republic of Argentina (2017), Tercer Plan de Acción Nacional de Gobierno Abierto de la República Argentina [Third National Action Plan of the Open Government of the Argentine Republic], https://www.argentina.gob.ar/sites/default/files/digital - tercer plan de accion.pdf.

Niles, N. and K. Fernando (2017), "Implementing the SDGs - Responding to the challenges of interconnectivity and balance", Southern Voice Occasional Paper Series, Vol. 39.

OECD (2016), OECD Territorial Reviews: Córdoba, Argentina, OECD Territorial Reviews, OECD Publishing, Paris, https://dx.doi.org/10.1787/9789264262201-en.

UN (2017), Integrated Approaches for Sustainable Development Goals Planning: The Case of Sustainable Development Goal 6 on Water and Sanitation, United Nations, New York, https://dx.doi.org/10.18356/0ca8f8ae-en. 
66

UN Women (2018), Turning Promises Into Action: Gender Equality in the 2030 Agenda for [12] Sustainable Development, https://www.unwomen.org//media/headquarters/attachments/sections/library/publications/2018/sdg-report-genderequality-in-the-2030-agenda-for-sustainable-development-2018-en.pdf?la=en\&vs=4332.

\section{Note}

1 After the last workshop, the results of each of the separate workshops were systematised and consolidated using equal weights $(25 \%)$ for the 4 different stakeholder groups. The goal was to find a final list of prioritised targets. New targets proposed during the workshops had to be endorsed by more than $50 \%$ of the stakeholder groups in order to be considered in the final prioritisation. This was the case for 6 out of 46 newly proposed targets. Targets, whose elimination was requested by three of the four stakeholder groups would have been excluded from the final list of prioritised targets but none of the targets reached that threshold. 
4 Policy recommendations and action plan

This chapter suggests some policy recommendations to enhance the territorial approach to the Sustainable Development Goals (SDGs) in the province of Córdoba, Argentina. The recommendations span from using the SDGs to develop a Vision 2030 for the province, designing policies based on input and suggestions derived from five clusters of the SDG matrix, all the way through strengthening the efforts to disseminate data and information on the SDGs to the public, and providing platforms for co-ordinating the actions of the private sector and civil society. The policy recommendations are accompanied by an action plan that provides concrete and practical steps for implementation, as well as inspiration from international practices. 


\section{Policy recommendations and action plan}

\section{Box 4.1. OECD Checklist for Public Action to facilitate and uptake the implementation of the SDGs}

The OECD Checklist for Public Action is directed to governments at all levels to facilitate the implementation of a territorial approach to the SDGs. The checklist provides action-oriented recommendations around five main categories:

- Planning, policies and strategies: Use the SDGs to define and shape local and regional development visions, strategies, plans and re-orient existing ones. Cities and regions should use the SDGs to address local challenges that require a holistic approach, such as clean forms of urban mobility, affordable housing, gender equality, access to green spaces, balanced urban development, clean water and sanitation, air quality, solid waste management, territorial inequalities or service delivery.

- Multi-level governance: Use the SDGs as a framework to align policy priorities, incentives, objectives across all levels of governments as well as to manage trade-offs and promote synergies across policy areas. In particular, regions and cities should be engaged in the process of Voluntary National Reviews to reflect progress at the subnational level and address regional disparities. Voluntary Local Reviews can also drive better multi-level governance of the SDGs and shed light on local initiatives.

- Financing and budgeting: Mainstream the SDGs in budgeting processes to ensure adequate resources are allocated for the implementation of the 2030 Agenda and to foster policy continuity across political cycles. Governments should allocate financial resources based on the identified place-based policy priorities and local challenges, and use the SDGs framework to foster multi-sectoral programmes and priorities.

- Data and information: Leverage SDG data and localised indicator systems to guide policies and actions for better people's lives, and to showcase the performance and positive stories of cities and regions. In particular, for more comprehensive assessment and policy responses, cities and regions should combine data and indicators at different scales, including administrative boundaries (unit for political and administrative action) and functional approaches (economic geography of where people live and work).

- Engagement: Use the SDGs as a vehicle to enhance accountability and transparency through engaging all territorial stakeholders, including civil society, citizens, youth, academia and private companies, in the policy-making process. Cities and regions should use a combination of various tools to engage local stakeholders, such as awareness-raising campaigns, networking opportunities, but also de-risking investments in SDG solutions through grants or loans, as well as a fiscal incentive for innovative solutions towards sustainability.

Source: OECD (2020[1]), A Territorial Approach to the Sustainable Development Goals: Synthesis Report, https://doi.org/10.1787/e86fa715-en. 


\section{Box 4.2. OECD Action Plan for a territorial approach to the SDGs in Córdoba}

The main objective of the action plan is to provide Córdoba with a menu of options for the implementation of the OECD recommendations contained in the SDG draft pilot case. The action plan sets out a series of specific actions aiming at supporting Córdoba's implementation of the SDGs. In particular, it identifies:

- Objectives: The action plan presents a number of objectives for each of the recommendations, in terms of expected outcomes.

- Practical steps: The action plan includes a set of actions that can be useful in advancing towards the achievement of the objectives.

- Possible champions and partners: This section refers to the stakeholders, institutions or organisations that can play a (leading) role in the execution of the actions.

- International experiences: These experiences include relevant practices carried out in the field of localising the SDGs by cities, regions and national governments as well as international organisations that can serve as inspiration. These experiences are not expected to be implemented as such but to provide the region/municipality with a set of examples for the design and development of the suggested actions.

- Timeline: In order to implement the recommendations efficiently, recommendations must be prioritised within the short, medium and long terms. These time scales are indicative and should be updated as actions are being implemented.

It is important to note that:

- Actions are neither compulsory nor binding: Identified actions address a variety of ways in which recommendations can be implemented and objectives achieved. They represent suggestions, whose adequacy and feasibility should be carefully evaluated by Córdoba in an inclusive manner, involving stakeholders as appropriate. In turn, the combination of more than one action can be explored, if necessary.

- Resources for implementation should be assessed: The implementation of the actions will require human, technical and financial resources. When prioritising and assessing the adequacy and feasibility of the suggested actions, the resources needed to put them in practices should be carefully evaluated, as well as the role of stakeholders that can contribute to the implementation phase.

- The action plan is a dynamic tool: It requires updating as new potential steps and objectives may emerge as actions start to be implemented.

\section{Key recommendations for Córdoba}

The following policy recommendations were developed through the policy dialogue with a wide range of stakeholders in Córdoba with a view to moving forward with the territorialisation of the SDGs in the province. They follow the OECD Checklist for Public Action to facilitate and uptake the implementation of the SDGs (Box 4.1). Figure 4.1 summarises the recommendations. 
Figure 4.1. Seven key recommendations for a territorial approach to the SDGs in Córdoba

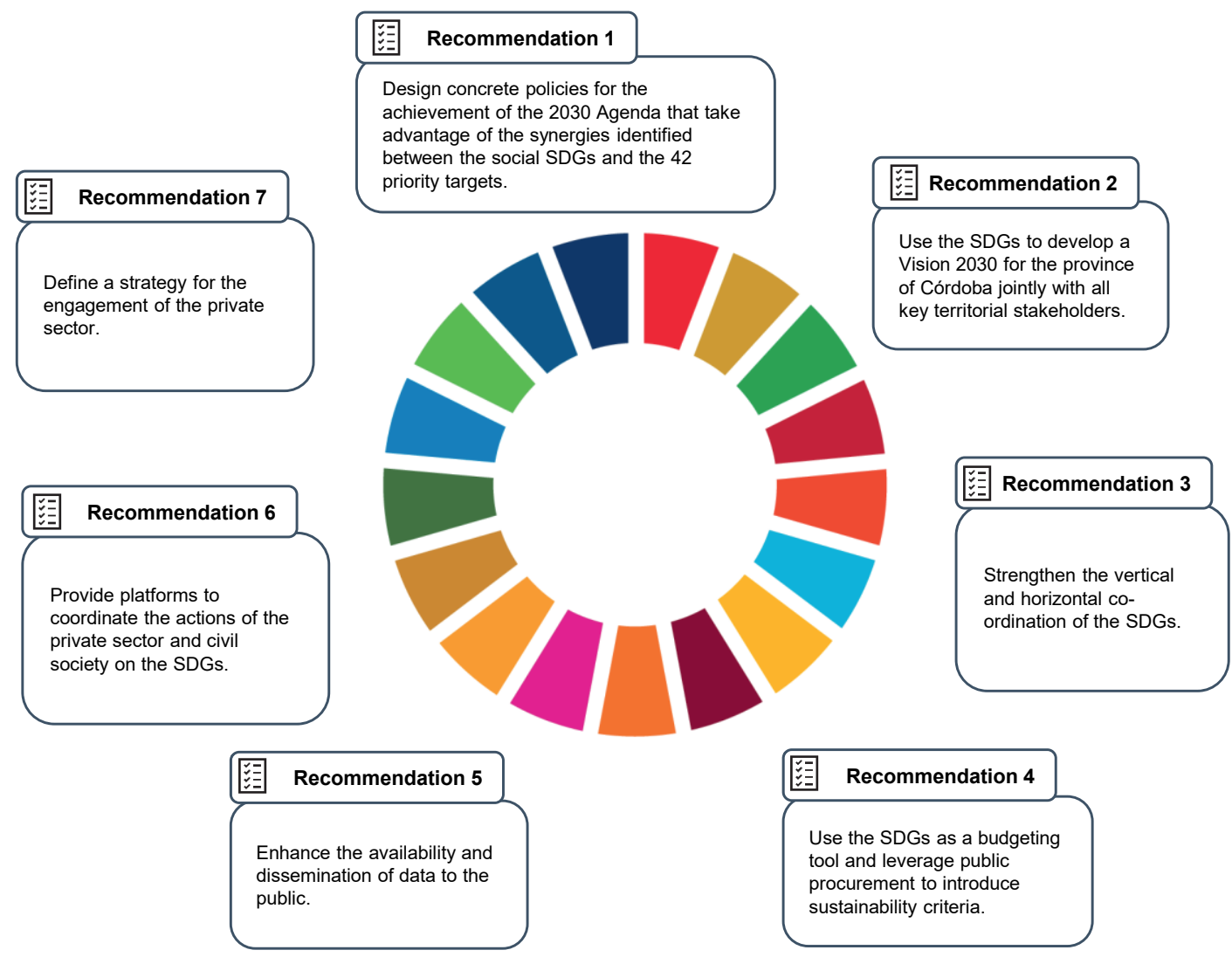




\section{Planning, policies and strategies}

\section{Figure 4.2. Action plan to implement OECD Recommendation 1 to design concrete policies for the achievement of the 2030 Agenda - First part}

\section{Recommendation 1}

- Design concrete policies for the achievement of the 2030 Agenda that take advantage of the synergies identified between the social SDGs and the $\mathbf{4 2}$ priority targets.

The collaborative SDG territorialisation process in Córdoba has revealed numerous interlinkages between the social SDGs and the priority targets and led to the development of five concrete strategic lines of actions and policy proposals. As a next step, concrete policies that take advantage of the priorities, synergies and concrete actions identified from the matrix should be implemented.

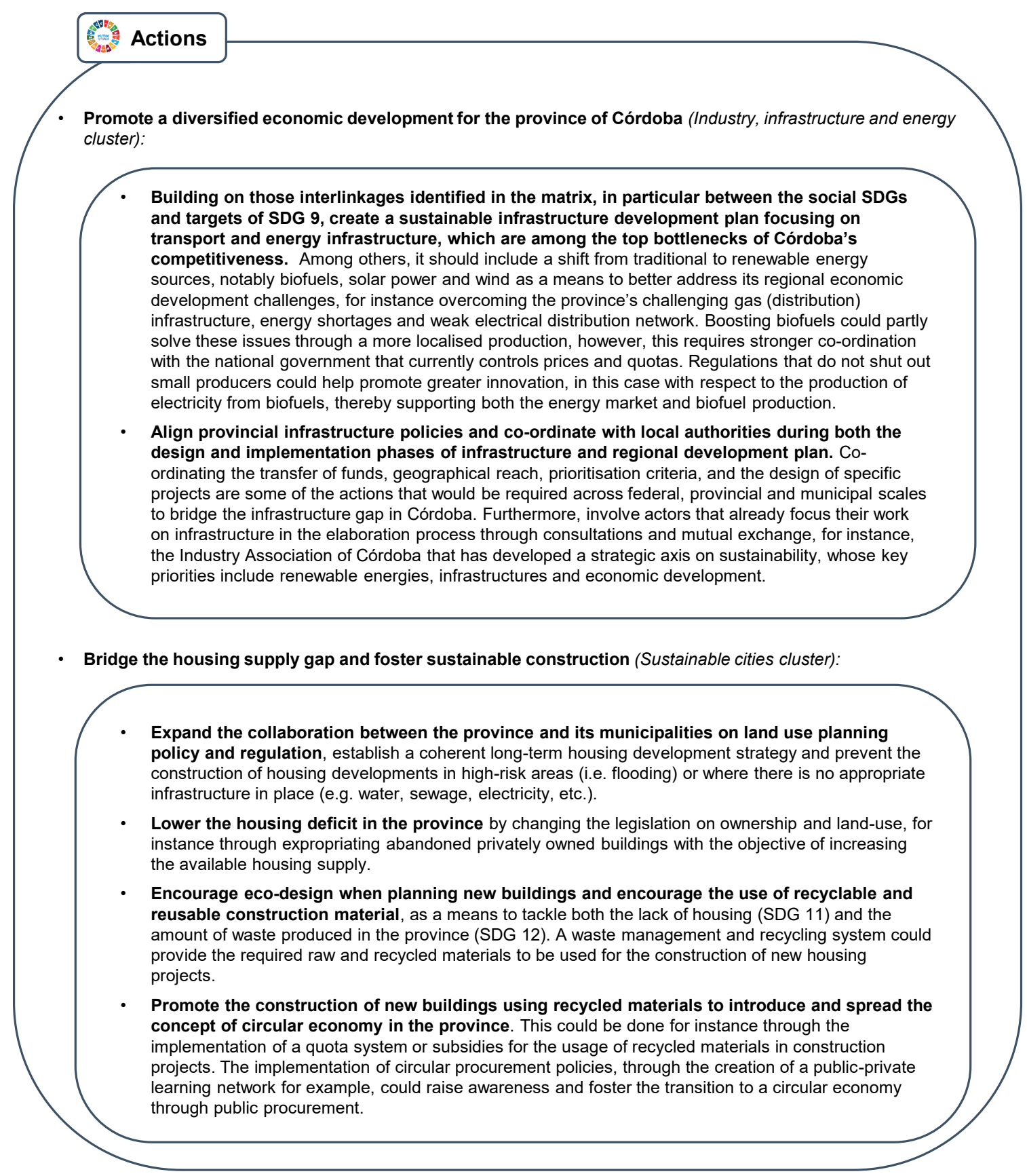


Figure 4.3. Action plan to implement OECD Recommendation 1 to design concrete policies for the achievement of the 2030 Agenda - Second part

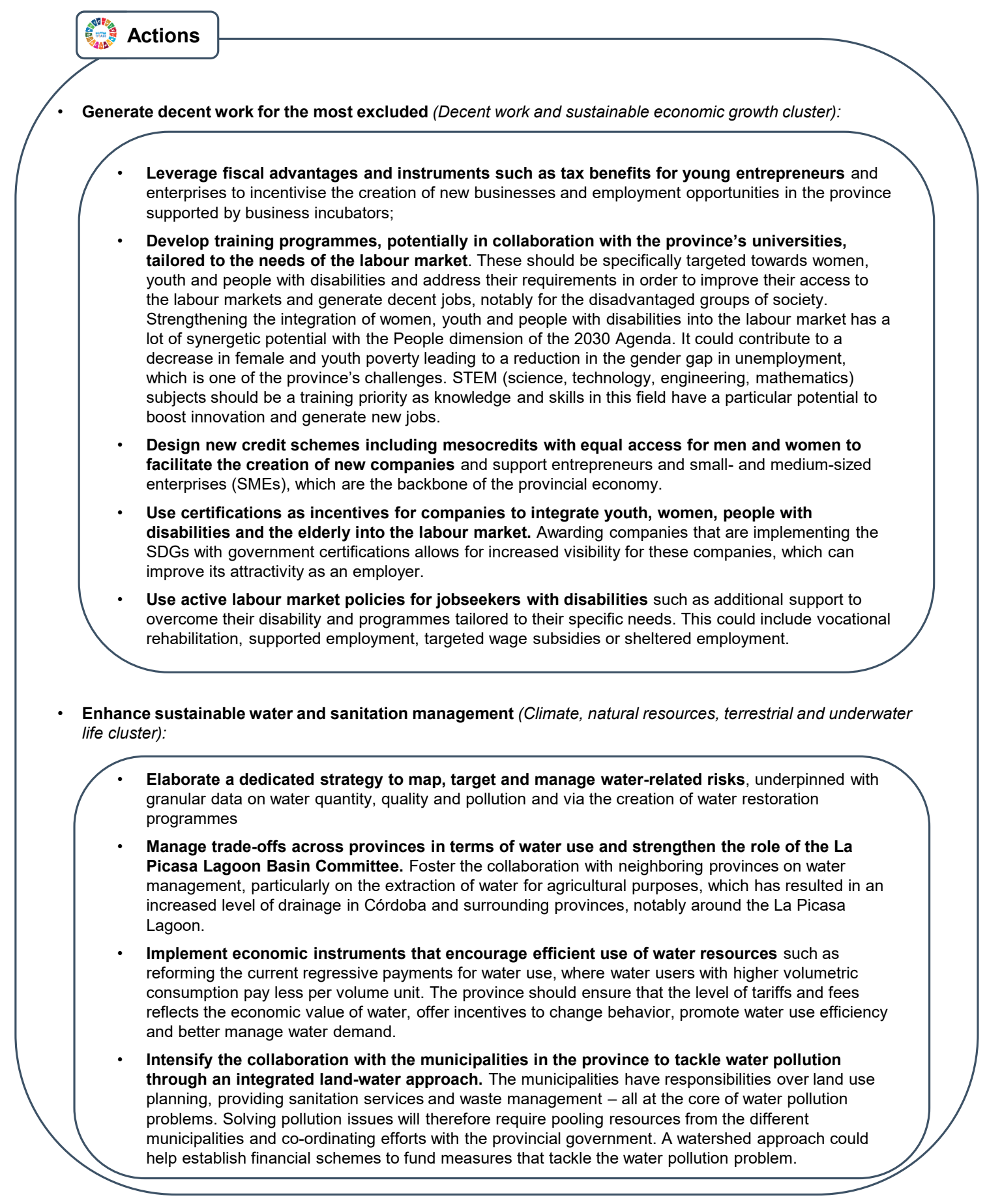


Figure 4.4. Action plan to implement OECD Recommendation 1 to design concrete policies for the achievement of the 2030 Agenda - Third part

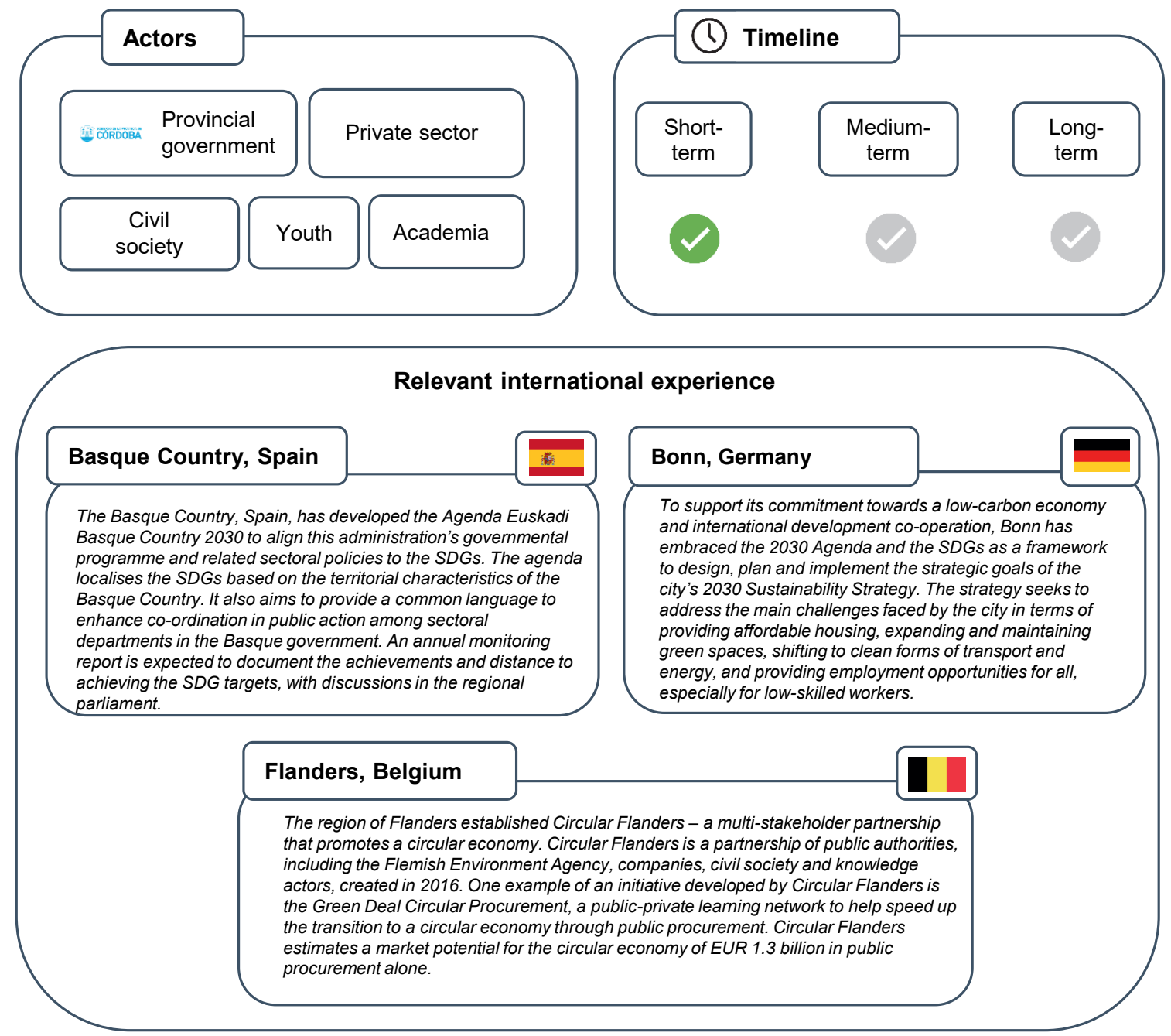


Figure 4.5. Action plan to implement OECD Recommendation 2 to use the SDGs to develop a Vision 2030 for the province of Córdoba jointly with all key territorial stakeholders

\section{Recommendation 2}

- Use the SDGs to develop a Vision 2030 for the province of Córdoba jointly with all key territorial stakeholders.

The results of the SDG matrix that the province of Córdoba has developed and the timeframe of the 2030 Agenda provides an appropriate conceptual and operational framework to jointly define a vision for the province of Córdoba with the provincial stakeholders. Such a vision should contribute to the elaboration of a formalised regional development strategy aiming at the diversification of the provincial economy, a strengthened participation in global value chains and sustaining well-being.

\section{Actions}

- Take advantage of the stakeholder consultation related to the SDG matrix to define the provincial priorities around the five strategic lines of action proposed by the stakeholders.

- Building on the provincial ambition to expand the joint work with local stakeholders, generate new spaces for collaboration among provincial actors. Take advantage of such a participatory approach by integrating stakeholder opinions into the elaboration of Córdoba's Vision 2030, building on the SDG matrix exercise and successful examples of participatory approaches already in place in Córdoba, such as the neighbourhood councils and neighbourhood centres.

- Use the Government Management Report to track progress on the implementation of the regional development strategy once it is developed.

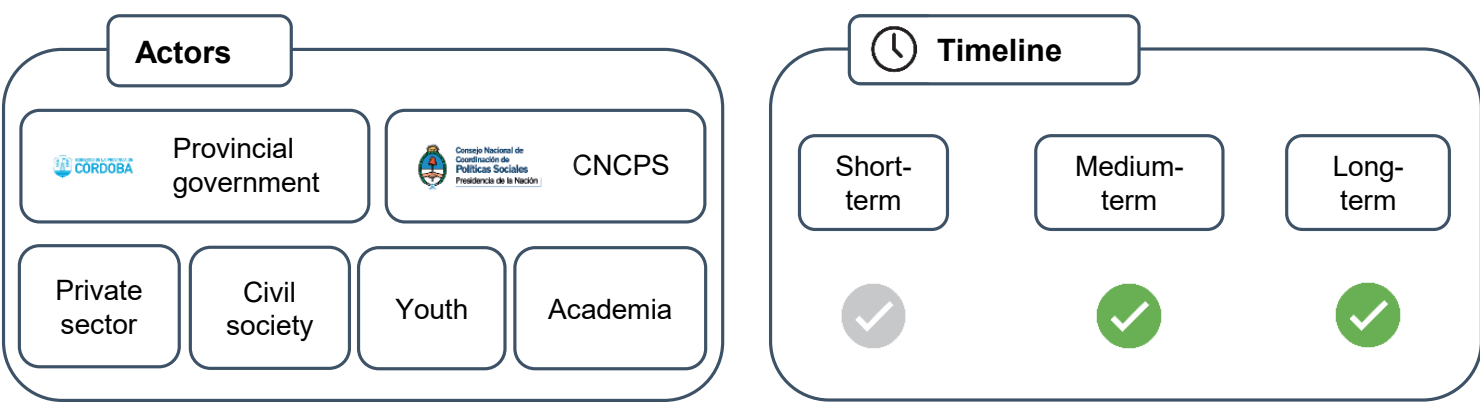

Viken, Norway
$\begin{aligned} & \text { The county of Viken has endorsed the SDGs as a holistic } \\ & \text { framework for the strategic planning and future } \\ & \text { regional development strategy A Regional Planning } \\ & \begin{array}{l}\text { Strategy for a Sustainable Viken 2020-2024. Through this } \\ \text { strategy, Viken is focusing on utilising the SDG framework } \\ \text { for governmental transformation, drawing on the best } \\ \text { available knowledge and indicators for the county and } \\ \text { identifying the planetary boundaries within which long-term } \\ \text { sustainability can be achieved. }\end{array}\end{aligned} \begin{aligned} & \text { The region of Southern Denmark has been incorporating the } \\ & \text { SDGs in the new regional development strategy (2020-23). } \\ & \text { The overall concept of well-being and quality of life, the six } \\ & \text { strategy tracks, the specific regional goals and as well as the } \\ & \text { action of the region are linked to specific SDGs and are } \\ & \text { designed to contribute to their achievement. The regional } \\ & \text { government has followed a thorough participatory process to } \\ & \text { engage local stakeholders in the development of this new } \\ & \text { regional development strategy. This includes a public } \\ & \text { consultation process with local municipalities, education } \\ & \text { institutions, museums and other interested parties, a } \\ & \text { dedicated "consultation conference" open to the public and a } \\ & \text { dedicated consultation with partners on the German side of } \\ & \text { the Danish-German border. }\end{aligned}$




\section{Multi-level governance}

Figure 4.6. Action plan to implement OECD Recommendation 3 to strengthen the vertical and horizontal co-ordination of the SDGs

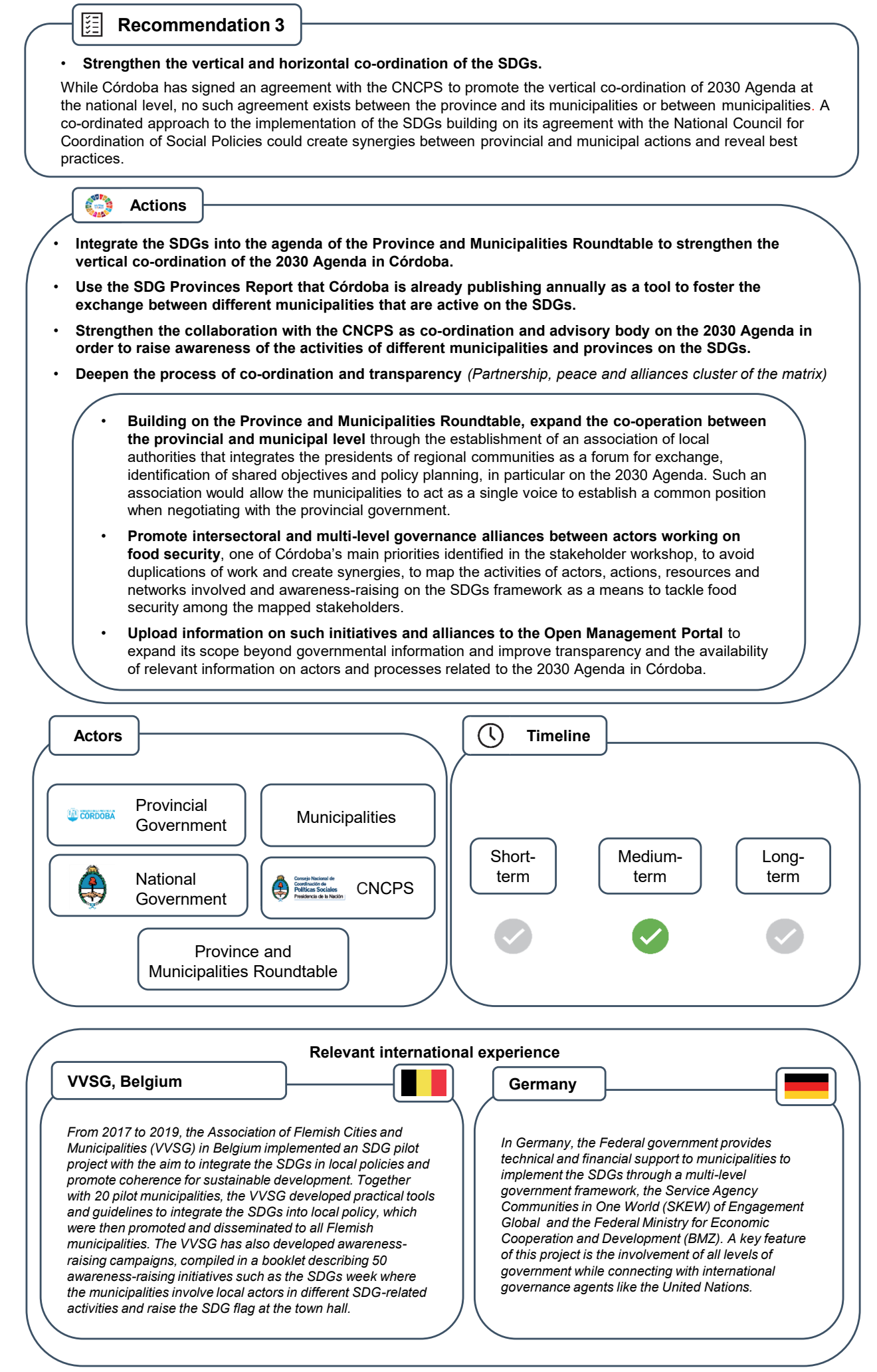




\section{Financing and budgeting}

Figure 4.7. Action plan to implement OECD Recommendation 4 to use the SDGs as a budgeting tool and leverage public procurement to introduce sustainability criteria

\section{Recommendation 4}

- Use the SDGs as a budgeting tool and leverage public procurement to introduce sustainability criteria.

Due to Argentina's federal structure, the province of Córdoba has a wide range of political authority and responsibilities. This provides Córdoba with good prerequisites to use the SDGs as a budgeting tool to prioritise resources towards the 2030 Agenda as a holistic framework within the various departments. In public procurement, sustainability criteria such as ISO certifications could help to foster the SDGs and incentivise public and private actors' initiatives for sustainable development.

\section{Actions}

- Define a certain share of public procurement that has to comply with sustainability such as ISO certifications to strengthen private sector involvement in the SDGs and provide an incentive for companies to integrate the SDGs into their business strategy.

- Use the SDGs to allocate resources towards the priority targets of the province, prioritising those policy areas and initiatives that generate the highest value-added towards the implementation of the SDGs.

- Use the experience of the SDG matrix exercise to involve key territorial stakeholders in the definition of budget priorities using a participatory approach.
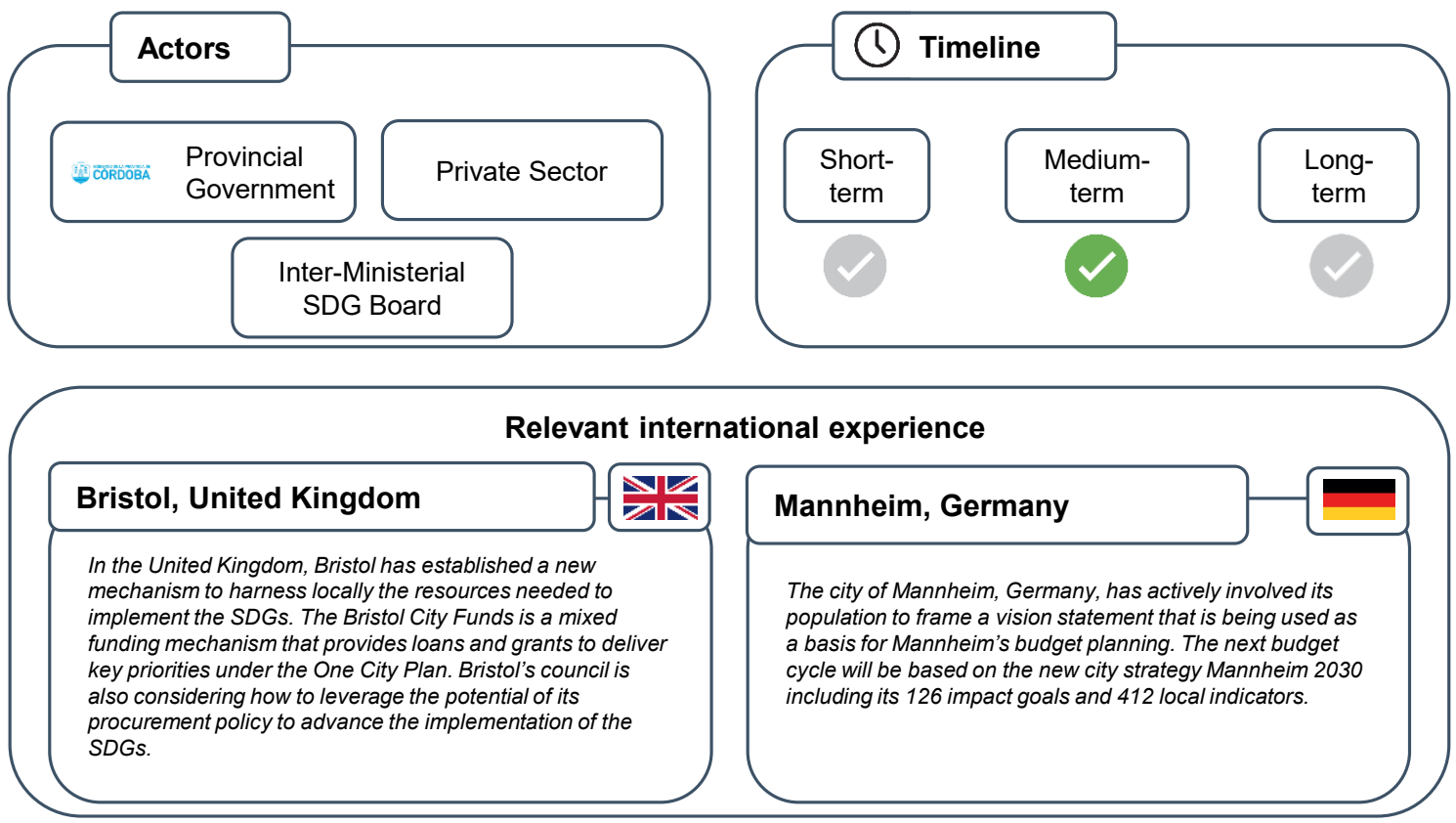


\section{Data and information}

Figure 4.8. Action plan to implement OECD Recommendation 5 to enhance the availability and dissemination of data to the public

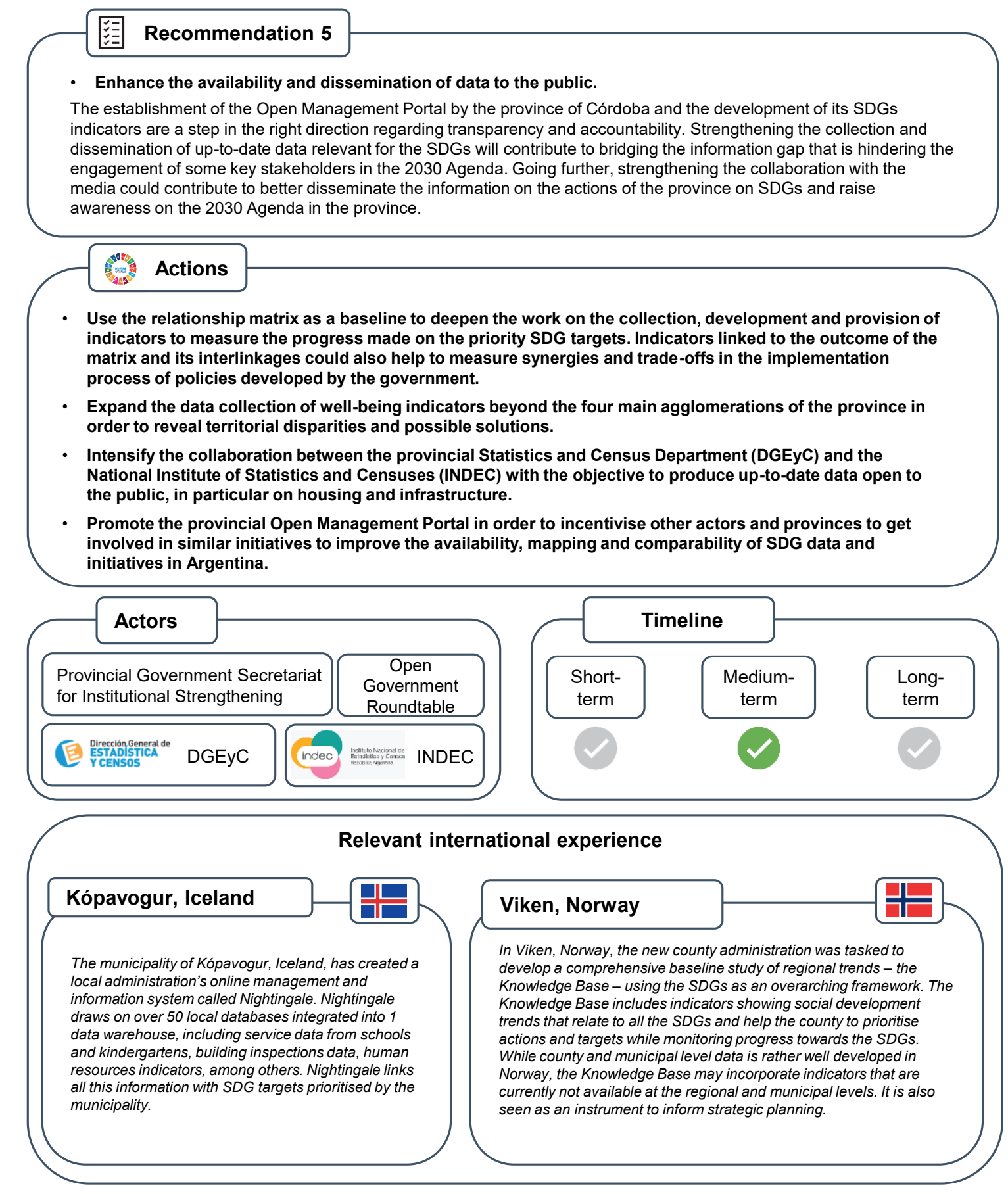




\section{Engagement}

Figure 4.9. Action plan to implement OECD Recommendation 6 to provide platforms to co-ordinate the actions of the private sector and civil society on the SDGs

\section{Recommendation 6}

- Provide platforms to co-ordinate the actions of the private sector and civil society on the SDGs.

The establishment of the Córdoba SDG Forum is a good example that could however benefit from a higher degree of institutionalisation. Such institutionalisation should possibly be incorporated into the framework of a 2030 Vision for Córdoba, where all the actions of the public and private sector as well as the ones of civil society can contribute to shared and common goals.

\section{Actions}

- Expand the scope of the SDG Forum beyond being an informal space for analysis, debate, dissemination, promotion and awareness of the SDGs. The forum could become a more institutionalised and permanent body connecting various actors from academia, civil society and the private sector engaged on the SDGs and take an advisory role for the provincial government and its work on the 2030 Agenda.

- Use the Open Management Portal as a platform for exchange on the private sector's and civil society's engagement on the SDGs, including by presenting best practices.

- Make the co-ordination platform and tools part of the regional development strategy to emphasise the importance of co-ordinated actions on the 2030 Agenda.

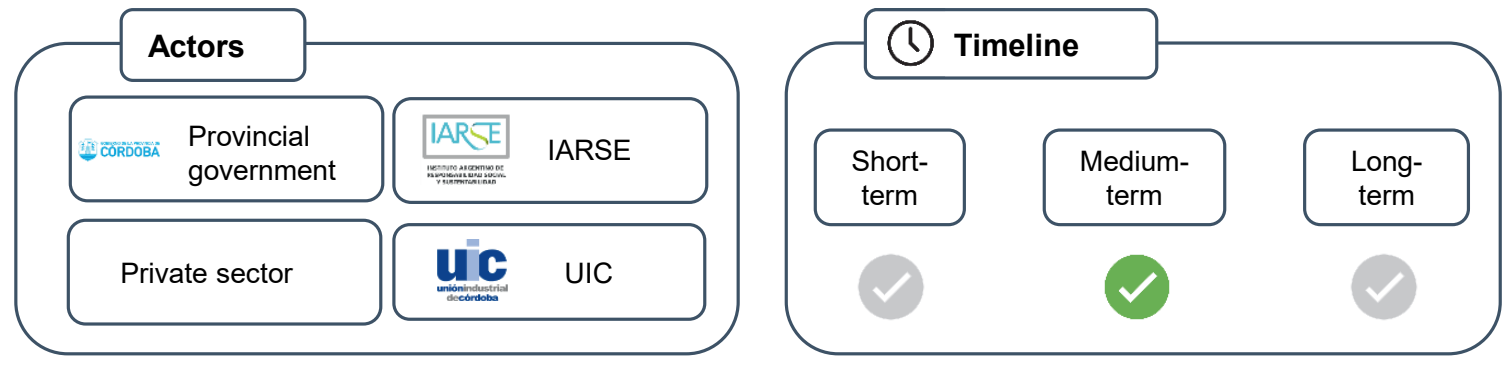

\section{Relevant international experience}

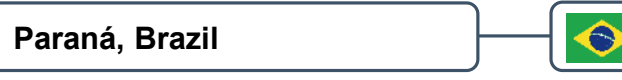

Paraná, Brazil, is promoting agreements with the private sector and civil society to implement the SDGs. The state is using the "Paraná de Olho nos ODS" (Paraná keeping an eye on the SDGs) pledge to gain public support from a wide variety of institutions including state, private sector and civil society actors.

\section{Kitakyushu, Japan}

The city of Kitakyushu, Japan, has set up a Kitakyushu City SDGs Council, which is expected to provide advice on the actions and directions regarding the implementation of the SDGs through the engagement of various stakeholders from civil society, private sector, finance and academia. The council consists of eight experts from environmental, economic and social fields. The city also created the Kitakyushu SDGs Club, where anyone in the city can contribute proposals regarding the implementation of the $S D G s$ in the city. 
Figure 4.10. Action plan to implement OECD Recommendation 7 to define a strategy for the engagement of the private sector

\section{Recommendation 7}

- Define a strategy for the engagement of the private sector.

Several companies in Córdoba are addressing the SDGs in their work despite not being fully aware of the link. In order to spread knowledge and awareness of the SDGs, Córdoba should define a strategy aiming to engage the private sector. A key role in the strategy could be played by the province's Open Management Portal to collect and share good practices related to SDGs. Collaborations between the province, the Argentinian Institute for Corporate Social Responsibility and the Industry Association of Córdoba could be another means to co-ordinate actions of the private sector and foster their engagement in the 2030 Agenda.
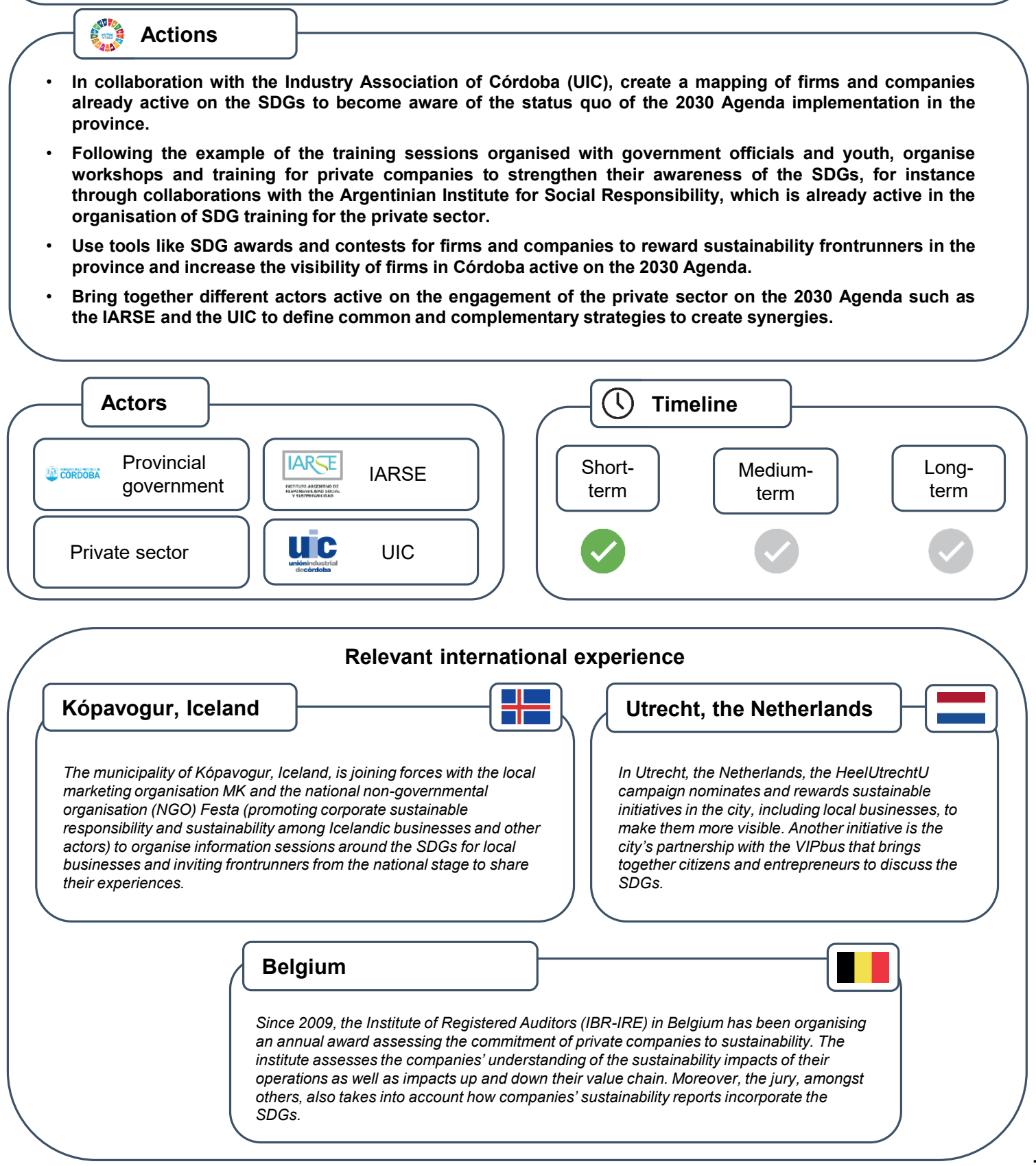


\section{References}

OECD (2020), A Territorial Approach to the Sustainable Development Goals: Synthesis report, OECD Urban Policy Reviews, OECD Publishing, Paris, https://dx.doi.org/10.1787/e86fa715en. 
More information: oe.col/sdgs-local

Follow us on Twitter: @OECD_local

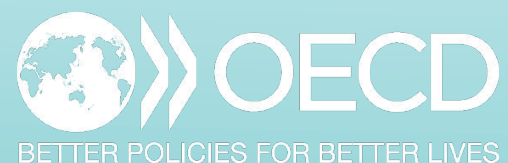

